\title{
CLINICAL AND HISTOPATHOLOGICAL STUDIES OF CHRONIC SUPPURATION OF THE TEMPORAL BONE ACCOMPANIED WITH SEVERE HEARING LOSS
}

\author{
By \\ K. YASUDA \\ Niho Oto-Rhino-Laryngological Institute, Yokohama \\ (Director: S. Niho, M.D.)
}

The author reports clinical and histopathological studies in seven cases with chronic suppuration of the temporal bone accompanied with severe hearing loss. The specimens examined were taken from each part the temporal bone at the radical or conservative radical operation (S. Niho) for osteomyelitis of temporal bone.

(1) In recent years, since the advent of chemo-antibiotic therapy, the findings of the ear drum of patients with chronic suppuration of the temporal bone are less significant compared with histopathological findings of the specimens taken from the temporal bone. Of most importance are $\mathrm{X}$-ray findings of the temporal bone especially in infants.

(2) Among the many reported methods of X-ray study of the temporal bone, Stenver's position is the best, and films taken in this position revealed more or less manifest pathological changes in all of these seven cases.

(3) In prevention of chronic mastoiditis and petrositis it is necessary to eliminate disorders in the nose and throat, performing tonsillectomy and adenoidectomy even if the patients are only one or two years of age. It is also necessary to perform attico-mastoidectomy or conservative radical operation for osteomyelitis of temporal bone, even in infants.

(4) In such severe cases in young children, chronic pneumato-cellulitis, osteitis and osteomyelitis are observed histopathologically. However, in long standing cases especially these in whom more than twenty years had elapsed, chronic pneumato-cellulitis is very rare and chronic osteitis and osteomyelitis are demonstrated.

In the soft tissue, thickening of the epithelium, edematous swelling of subepithelial and periosteal layers, infiltration of polymorphnuclear leucocytes, histiocytes, plasma cells, round cells : and sometimes eosinophile leucocytes, granulation tissue and its organization, etc. are observed.

As histopathological changes of the bony tsisue removed at the operation of the temporal bone, the following findings are revealed: marked degeneration, for example, pycnosis or disap: pearance of the bone nuclei, indistinction or disappearance of bone lamellae, appearance of abnormal lamellae, chemical absorption of the bone (halisteresis), bone necrosis, absorption by osteoclasts (lacunar absorption), absorption by granulation tissue, widening of bone cavity, another type of porosis, widening of Haver's canaliculi and other bone canaliculi, increase of bone canali-: culi in. a broad sense and of. the marrow tissue, osteoporosis, circulatory disturbance of fluid, edema and fibrosis in the bone canaliculi in a broad sense or in the marrow tissue, appearance of osteoblasts, bone proliferation and appearance of osteoid tissue, etc.

Summarizing the above mentioned findings, bony damages. may disturb the healing of soft tissue, and circulatory disturbances of fluid in soft tissue may disturb the healing of the bone tissue. 
(5) As a result of existence of these pathological changes around the labyrinth for a long time, development of osteoporosis of the bony capsule of the semicircular canals with eventual labyrinthitis has been demonstrated. In the author's opinion similar pathological processes may occur sometimes in the cochlear capsule and in such incidences circulatory disturbances of fluid or inflammatory changes may have some influence on the cochlear function, which may become gradually less active and conductive deafness may become mixed deafness.

Accordingly, for restoration of the cochlear function, it is of importance to eliminate such damaged bone tissue around the cochlea by performing the radical operation for osteomyelitis of temporal bone recommended by $S$. Niho.

\title{
慢性側頭骨炎による高度難聴者の臨床並びに 側頭骨の病理組織学的研究
}

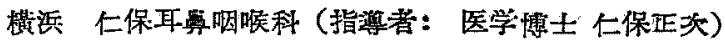 \\ 医学士 安 思和 秀
}

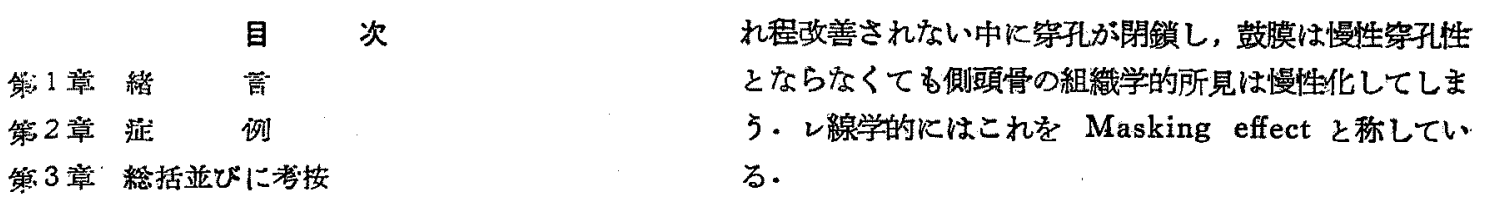

第 4 章結語

\section{第 $\mathbf{1}$ 章 緒 镸}

近时化学接生物質の進歩により，これ等の薬郕の無か つた当時の華やかな急性乳樣乫起炎の手術は殆ど無くな つてしまつた・しかしこの反面には，発㷫，耳痛等つ患 者にとつて耐兄難い苫痛は隠蔽され，恰も臭いるのに蓋 式つ治療が行われ，却つて聴力改善のための手術の苦期 を失している感が梁い。

外界よりの音のエネルギーの波は伝音系を経て内耳に 入り, 動力のェネルギーは化学ェネルギーとなり, 更に 電気ェネルギーに変化されて大脳に伝えられる。即ち聴 覚に就いて最も重要なのは内耳であり，次が伝音機棈で ある・近時伝音機構の柘究の発達の余り, 内耳が眯が されている感が梁い。

耳管を介して鼓室に感染が起り，㑡頭骨含気蜂穼炎と なり，更に側頭骨炎，側頭骨骨膸炎となり，やがては含 気蜂窠，側頭骨の炎症は慢性化し，鼓膜所見も穿孔し， あるいは無穿孔の儘で長期の経過を辿る・化学抗生物質 の出現は、これ等の薬剂の無からた時代には鼓膜に穿孔 し排膿されたものも，無穿孔あるいは側頭骨の病变がそ
即ち鼓膜所見では治痛，中耳加答兄，又は中耳炎残眙 症、レ線所見では Masking effect, 組織学的には慢性 側頭骨炎之同一疾患て色々の立場から種々の彭断が下さ れる.更に後述の乳奻巟では聴力の立場からストマイ難 聴あるいは䱾の䛦断す下される。

このストマイ難聴の診断は聴力に関しては死刑の宣告 に等しく，他て総ての原因的突患鑑別除外してからで なくては下してはならない事は，後述の症例道自ら 明らかであらう。

聴力の経過に就いては初め伝音采が侵され，その後急 性増悪を繰り返す中に内耳を侵され，混合難聴となり， 更に症例の如き高度難聴となる。

次急性あるいは慢性側頭骨炎即ち乳様突起炎及び錐 体炎の骨病理に就いては Scheibe 2), Neumann 3), Lange ${ }^{4)}$, Krainz ${ }^{5)}$, Tobeck ${ }^{7)}$, Richter ${ }^{9)}$, EckertMöbius ${ }^{6)}$, Mayer ${ }^{8)}$, 二階堂 ${ }^{14)}$, 小田 (醇) ${ }^{15}$, 高原 (高) 16)，猿渡 18)，仁保 (正) 17) 19) 20) 21) 92) 27) 299399，平 野 19) 21)，仁保 (三) 21) 24) 27) 46)，吉尾 26) 47) 48) 50) 519，井 沢 23)，永井 24)，石川 26) 26)，高畑 ${ }^{403}$; 吉田 ${ }^{45}$, 佐野 60) 等林挙に遑がないしかしながら従来の骨病理を翻つて 
みるに胃新生破壊が主に論ぜられ，骨組織乞のものは等 關泭されてきたかの感が梁い，而して斯かる变化る急

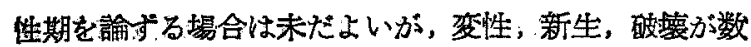
年；10数年あるい记それ以上る繰り返された慢性症を 論ずるには極めて不充分である。

今近世病理解剖学 ${ }^{30)}$ を開いて我くに必要な部分を簡 単て拾つてみると，骨の消耗に際して起る組織的变化と

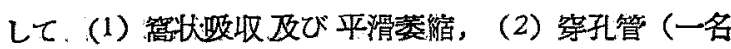
Volkmann 管)，（3）脱灰 (Halisteresis). 急性骨炎,

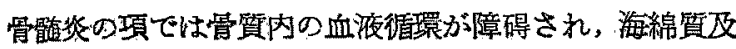

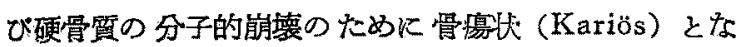
る・慢性の経過をとる時には周囲骨膜に強い、骨質の増生 ををたし甚だ不正に肥厚する・又慢性線維性骨膜炎は骨 膜江強い線錐性の肥厚をきたん，骨形成性骨炎 (Ostitis ossificans) 及び骨硬化症 (Osteosklerose) で注骨骮有

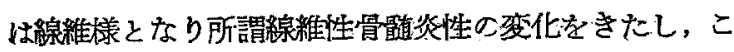
れが骨組織俰移するるので，同時火従来つ骨梁表面 飞造骨細胞が堌生し骨新生をさたす・このために骨質は

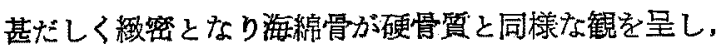
Havers 管 (以下八管) 而質の新生により充塞され益 々維密となる・これを骨硬化 Osteosklerose と称し， 高度なるのを象牙質様变性（Eburneation）飞䅫付る。 畸型性骨资 (Ostitis deformans) の項で恃骨筫は不規

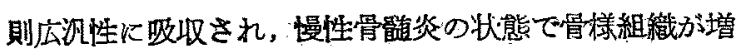
生し，石灰を含まない部分が多くなる・この場合の骨の

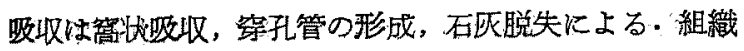
的特倒は骨質の Mosaik-struktur で骨層板は不規則地 図状の接合質比つて Mosaik 状をなす, 㕛線維性骨

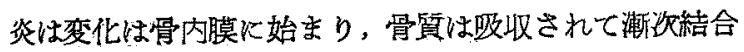

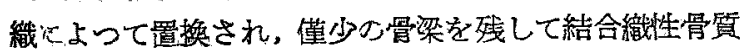
を形成する。

しかしながら後述の組織的变化は更に椱雑で，これ等 の記載のみでは到底表わす事はできない，又斯かる変化 が所謂慢性中耳炎て側頭骨る現われに事は全く記載され ていない.

Eggston, Wolff 1) $の$ Histopathology of the E. N.T. を見ても変性としては Necrosis of bone, 骨破

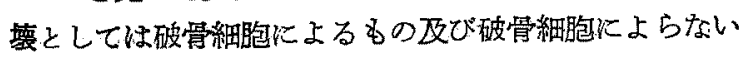
化学的吸収 (Halisteresis), 造骨細胞による新生，石灰 の沈着，類骨組織の出現，これ等により元の形より更に

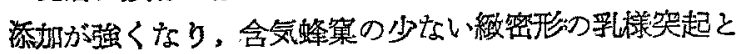
なる. 即ち Halisteresis が極めて広義に 解されている が，慢性側頭骨炎の骨病変の記載には極めて不充分であ
当。

そこで著者はへマトキシリン・エオジン重染色（以下 ヘ・理染色々略す），ワンギーッン染色（以下ワ染色 と略す）のみで性不充分で，洗定不能つ所見も多々ある が，その所見の儘を言葉见表わして以下の記載を行つ。 た・含気腔被㠅組織の組成の決定も未だみない今日であ るので御了承請ら炏第である. 以下そその代表的なるの に就いて述べて見度いと思う。

先ず從来の炎症の概念を炎症反応とすれぱ，炎症反店 は血管を介して現れる・從って骨組織の血管は管迄し かないから笅密な意味では骨炎はなく，その間筫の軟部

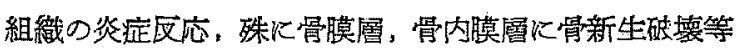
が現われたるのを骨资と呼えでいる。

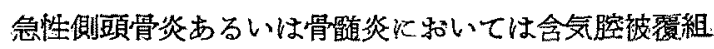

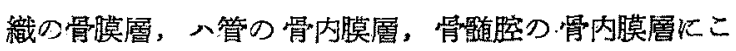
れ等の変化が現れる・これ等は元来が一連のすのであ b.

仁保 ${ }^{18)}$ (1942) は急性側頭骨含気蜂䆞炎をその程度に より次のよう火分類した・即ら

（1）急性加答児性含気蜂粢被夏組織炎

（2）急性化膿性含気蜂寔被覆組織炎

（3）急性化膘性含気蜂巢炎

（4）急性限局性骨炎市るいは骨随炎

（5）急性広沉性骨炎あるい怯骨融炎

（6）急性進行性壊死性霄炎あるい情骨髄炎

である.この (3)，(1)，(5)，(6) は骨膜層，骨内膜層" の侵される部位及びその籍囲により泆定されるいのであ． る.

所が慢性症となると骨つ営盖, 体液循環を司る腔は含 気腔，骨骴膑，八管のみではない大ななるるのは含気 膑，骨路腔，これ等の肉芽あるいは浮腫性の組織で充た されたるの，むるいは骨破壊腔である。中位のるのは八

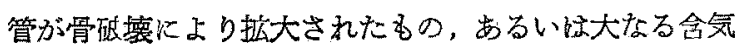

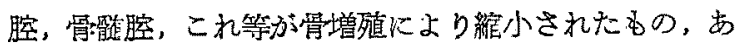
るい忙れれ等す腔つ突起を横切れれ゙中位の腔となる。 この正常あるいは急性期では余り見られない所見が梄め て多く見られる。これは本訜文では骨小管とした・后義

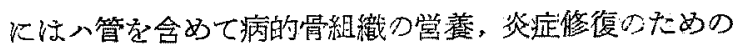
体液循環を司る小管を学小管と総括した。これん組織標 本上では以上のものそれぞれの区分が不可能であり，却

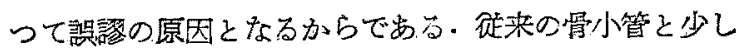

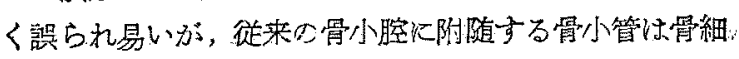
管之改名さ机てい. 
ハ管に就いても長年月間破壊新生が繰り返された慢性 症火执いては，正常のものよりる遥か炏その数が多い。 元来扁平骨汇执いては骨膜の血管より営養を受けるか ら，人管も長管骨程には必要でない。しかし慢性症にお いては営養を司る他に，骨病变の修復のための血行が必 要であり，偦つてその数が多い．しかし反対に八管が新 生骨て埋められて消失した所見も見られる・これは䯚が 縹密化し，それ程つ血行が必要でなくなつた所見であ る.

次に骨の変化の概略を述べう．先厄る述べたように 骨の変化はその営盖を司る周囲あるいはその内部の軟部 組織つ血行障碍，体液循獯障碍炕より起る変性が主であ る. 即ち第1は染色性が変化して奇麗にニオジン染色さ れず，へマトキシリンにも染まるようになる－同時に核 飞溽縮，偏在，消失等つ变化が起る，次は骨層板つ紋理 が不解明となり，あるいは消失する・これと共に骨小 管，八管の内壁がへマトキシリンに濃染する場合もあ る・又慢性症に括いては時代つ古い骨に隣接して時代の 新しい骨が存在し，その境界の接合楾はへマトキシリン に濃染する．これは多くは鋸雨状の線として現れる。 新旧の差は変泩の度合で判る．これつ高度のものが Mosaik-struktur である.

更に変性の甚だしい時は核は概小漹縮，消失し，骨小 膑は拡大し，骨層板の染まりが悪くなり，中間の部が却 つつていマトキシリンに染まり，異常紋理が現れる・更 に甚だしい時は骨質は融解し，へマトキシリンに染まる 線維様物質のみが残る。これを線維様化と命名した。骨 が結合織炕より置换され五 Ostitis fibrosa とは異なる ものである。

又核が消失し，管小腔が㹡大し，更に $2 \sim 3$ の拡大し た骨小腔が融合し，骨が孔だらけになる所見る見られ る.この腔侐管，肉茅が侵入すれば Volkmann 管の よらになるであろろ・文その所見が慢性化すれば先に述 べた骨小管つ所見を呈する事もあり得ると考充る・この 所見を多孔筫化と命名した。従つて Osteoporose とは 異なるものである。

㬝板間むるいは時代つ翼なる新旧の骨の境の接合質が 変化し，管が極めて脆くなりこれ等が離れてばらばら になつた所見が見られた・これは横浜医大病理つ吉村教 授に伺つたが，標本作成中の变化でないと・即ら手術洔

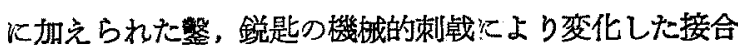
賀の部で離断せられたもので，これを脆弱化と命名し た・この離断所見は新旧の骨組織間に著明である。
斯かる新生䃌壊の 綝り返しである点よりして仁保 ${ }^{19 !}$ （1942）は側頭贿炎（所謂広義の中耳炎）を提唱し，慢 性側頭骨炎火就いてるレ線学的にあるいは組織学的に日 本耳䶊咽喉科学会総会，あるいは同関東地方会火おいて 10 数回子述べた.

最近吉田 ${ }^{45)}$ 性慢性中耳炎の骨病理火関する。研究火和 いて，（1）骨つ Umbau は70例中全例諮められた (2) 骨新生像は 70 例中 69 例火，骨破壊像は55例に認 められた．(3) 骨の Lamelle, Kittlinie の変動に注 意する事. (4) 骨病変の主体を為すのは骨新生像で, 密つもの多く，Ostitis ossificans 侅当すると述べて Wる.

又最近重野 41) は慢性中耳炎と Pneumatisations-hemmung の関保に就いての組織学的研究と題して乳様 洞周囲の蜂巢の組織学的研究を述べているが，これは含 気腔学説保捉われ過きている.

以上の見地より以下症例飞就いて記載して見度いと思 5 .

\section{第 2 章 症例}

\section{症 例 1}

患者：岡OよO.42 才. 什. 会社員

初診：昭和 30 年 5 月 20 日

主訴：両側高度難聴

既往歴, 家族歴：狩記すべき事項なし.

現病歷：雨耳共に耳疾患に雇患した記憶はなく，又 耳漏る一度も認めなかつたが，約 20 年前より左耳の難 聴を党えるようになり，その後左耳鳴（強くカーン，カ 一ン), 頭重，肩凝りあり，頭重のひどい時は眩渍; 湢 気学催した・某医を訪れ，左下甲介切除，左通気を1力 月受けたが好なく，鼓膜が混濁しているから諦めるより 什功ないと云われ，治療を中止したが，その後全く嚚 しなつてしまつた。

右耳注 10 年前より漸炊難聴をきたし，それと共に軽 い耳鳴 (カン，カン) が出現し, 感冒毎に強さを增し, 約 1 年前頃よりは約 1 米半離れると殆ど会話不能となつ た。昨年 10 月頃より感冒を繰り返し，その度毎に難聴 は高度となり，5月13日には右耳は閉塞したようにな り，殆ど開えなくなつたので，附近の某医を訪れ!週間 通気を受けたが更に悪化し，1 週間目には言語による意 志疎通は全く不能となり，本院を紹介されたすのである。 （な扢この病歴は左耳術後50日，右耳術後35 日目に会 話が可能氾なつてから取つたるのである).

初竞時耳科的所見：左鼓膜は弛緩部に穿孔の痕跡が 


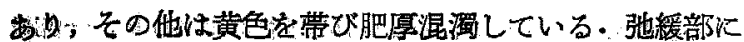

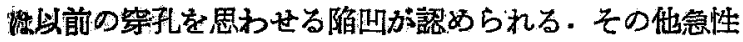
奖症症状は全く存在しない，右僦膜は全般に肥厚して特 ク，光沢を欠き，少しく黄色味を带びている・しかし右

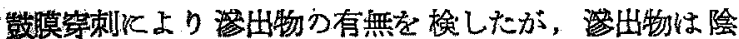

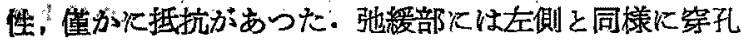
当を思わせる陷凹がある・即ち左側は明らが火乳幼紧期 飞慢性側頭骨炎火篗患し，その後所融中耳加答罗様の変 化を繰り返し，その間内耳火も侵憼？が加わって，遂沉 殆と権となり，右耳は化膿性慢性側頭骨炎か，所謂中耳 加答览より慢性側頭骨桨棌行したかどちらかであるう そ考えられた。

Stenvers $\nu$ 線写真所見：左耳は典型的な仜険性側 臯骨を呈し，乳様突起は小さく，乳様突起部上陵は強く 陷凹し，弓状隆起の頂上迄二段となつて，弓状隆起は突 出している：これは内耳等が先沉できてその後澄育す そ乳䇐突起が慢性乳㥞突起炎のために発育できないうめ 飞起る現象で，所謂危険性則頭骨を想起させ又一方には 乳奻罗期比相当な側頭骨炎汇䍜患した事を示している。

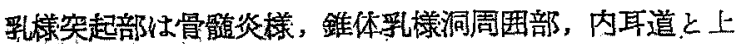
半規管の間，及び錐体尖む骨蹃炎様である。

右耳る同様の伦険性側頭骨で乳様突起上陵より弓状隆 起の原上までは階段状となつている・乳椂㔖起尖端こ蜂

图1第 1 洌衍前オージオグラム

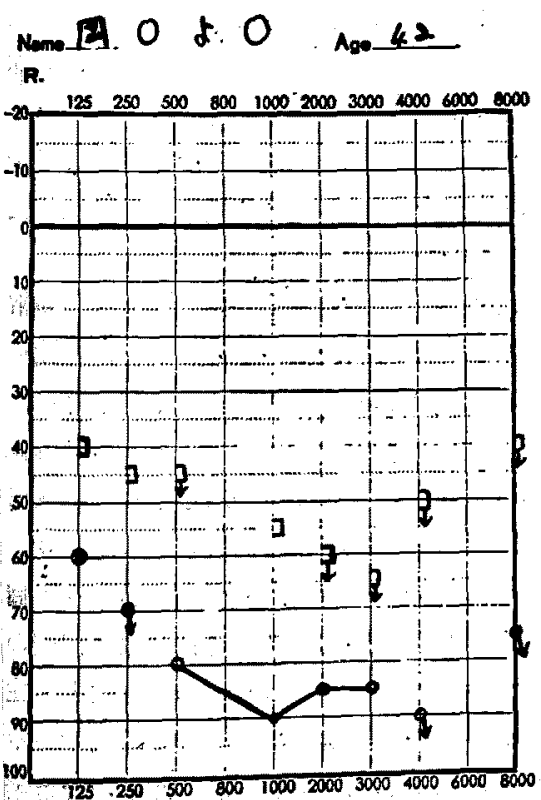

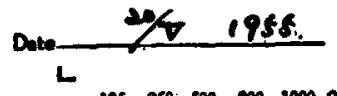

L $125 \quad 250.50000100020003000400000000000$

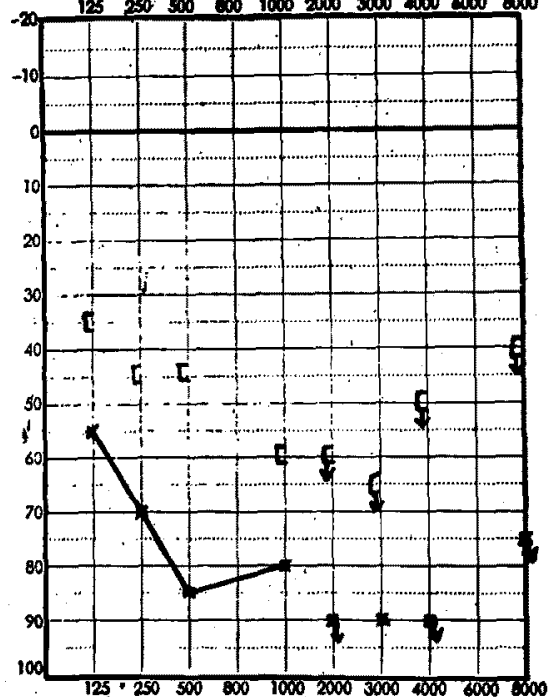

巢の融解した部分が認められ，乳様突起より迷路周囲部 にがげで不鮮明及び骨融解つ姿鍇した所謂骨䯘炎様の所 見を旺している。

聴力积亘所見：耳の傍でどんな大きな声を出しても 人間の言葉は聞党ない：しかし右耳の方は音だけは少し 聞学るらしい。

昭和 30 年 5 月 24 日左側頭骨炎根治手術+迷路開空術 を行い，6月 8 日右保存的側頭骨炎根治手術を行った。

左耳手術所見：型の如く外耳道上梀後方上り籢開を 行らに，蜂巢は一部肉芽により充たされ，骨增殖つた

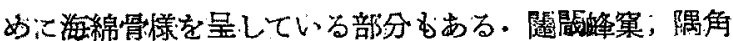
螺嫼の一部には肉眼的には被墰組織》浮腫と認められ

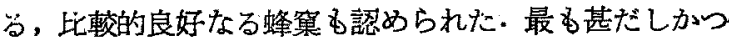
たつは哚部閨間蜂菓より仁保・吉尾て後蜂集列より後頭 顆火達する病竅で，一部海綿骨㨾にも見えるが，明らか

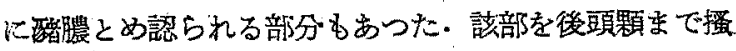
爬寸るに，挠頭部痛，房凝り，頸部门運動障碍は全く消 失した。乳様洞，上鼓室は被覆組織以腫張，粘破性脤汁 を認めたが，鼓膜所見より䈝われた仮性真珠嗹は認めら れなかつた。乳様洞内壁より錐体乳様洞周囲部至搔爬し た・所々に小蜂笨を有する海綿様霍患骨を蛋爬し，三半 規管を露出した，橋部を除去，耳小骨を除去し，更に外 耳道前壁を除去し鼓至を搔爬した・淁室被覆組織は浮婳

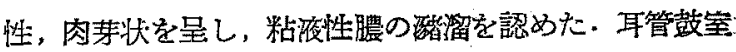
開口部外側骨壁を除去し，更 飞 Kopetzky-Almour 法て 錐体尖に入った・錐体尖む海 綿様で，鋭匙で摜爬する際の 抵抗は極めて軟らかく明らか に骨痽患を示していた・更に 仁保・平野式炕より錐体尖を 除去した・頭重, 肩㠜り等は 非常によくなつたらしいが， 恥力は余り変化がないのて開 空術を施行した・水平半規管 の前方膨大部つ直ぐ後ろに開 空し，膜様迷路を露出した 所，激しい脑最発作を生じ， 耳の傍で大声で哆鳴れば 返 事ができるようになつた。 Schambough 鈎伿上り骨空 粶を拉大し, 外淋巴腔を開放 


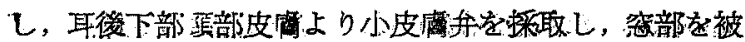

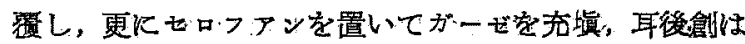
一期溥合して術を了した。

右耳手術所見：左耳同様やはり危険性側頭骨であつ た・左耳に比べ全体に蜂笨被覆組織つ炎症程泣は軽いよ ラに思われたが，狭少な閣閶蜂窠は骨が軟らかく，乳様

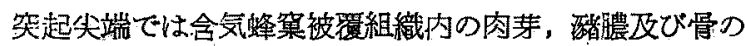

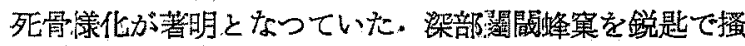
爬していると海綿状つ軟らかい骨が後頭顆まで続き，明 らか硣膿の諗められる部分もあつた。乳様洞及びその 周辺では，骨は脆くなつており，小蜂窠に粘膜の浮腫 が認められた・乳様突起天蓋, 乳様洞天蓋は広範侸硬脳 膜を露出し，S 状静脈洞も同様に露出した。更に乳様洞 迷路周囲部を水平半規管，後半規管を包む硬い奇簏な骨 壁を露出するまで除去した・上鼓室から耳小骨連鎖にか けては，疑われた仮性真珠腫の形成はなく，肉眼的儿左 側に比へ比較的良好であつたのでこれを保存した。従つ て梧部は耳小骨，鼓膜つ機能つ保全，外耳道の構造の保 秲つために保存し，外耳道後壁の外側半分を除去するに 止めた・患者俚約 $2 \mathrm{~m}$ 程離れた所より名前を呼ばれる そ返事をするようになつたつで，術創内にガーゼを充坨 して一期綘合を行った。

病理組織学的所見：手術㭙に 側頭骨各部より 採取し た組織片を軟部と共にッェロイジン包埋，へ・莗染色 及びワ染色により検索した。

左 耳:

（1）外耳道上束：最著明なつは骨つ变化で，骨層 板つ紋理は殆ど消失し, 通常つ骨組織よりはーマトキシ リンをよく取り，骨の脆弱化が著明で，ばらばらになつ た所見が見られる。骨小腔は㹡大し殆どの核は消失して いる・次に著明なのは骨小管つ㹡張で骨内膜はや小肥厚 し、へマトキシリンに㷂染し，その中心には血管が見ら れ，その他内腔は浮腫性つ組織がこれを充たし，Fibrosis が認められ，諸所詣肪䯣も見られる。細胞浸潤 は殆ど認められず，籍血は極めて軽度である．更に造骨 細胞ちるいは破骨細胞も認められず，全く治癒破壊機転 にそしい。

（2）乳様洞の外側壁：骨变化峙ほ今゙ 同様であるが拡 大せる骨小管，骨䯣腔，含気腔等は破壊吸収せられて肉 芽により監換され，通常は小含気腔が再生されて来る が，本例には全くそれが認められす，骨内膜は線維性の ヘマトキシリンに濃染する被膜となり，血管は摭張し， 浮隀, Fibrosis の認められる組織がその空間を充たす。

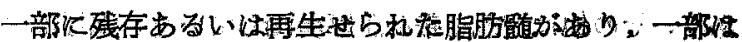

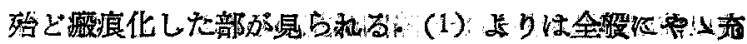

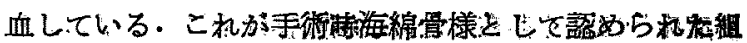
織と思初れる。

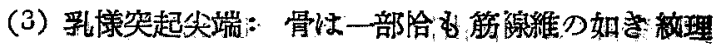

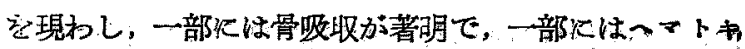

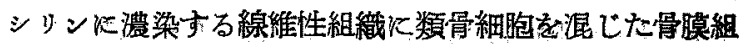
職上り筋組織炕移行している.

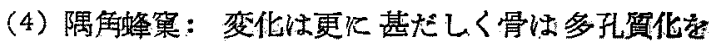
示している・一部缐穛性般底状となつた軟部組織の中に 泪長く立方状又は円柱上皮漾の小含気腔が見られる・し かし含気蜂杲内の炎症性变化は極めて軽度である。一部

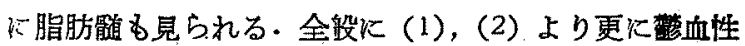
で动る。

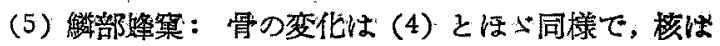
殆ど消失，多孔貿化を示し，合気腔，㹡大せる骨小管

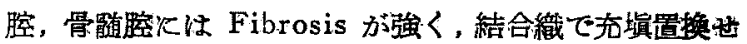

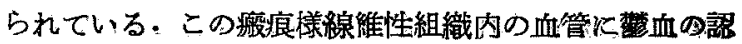
められる部分もあるが，細胞浸潤等の炎症性変化は極め てミしい.

（6）乳㥆洞天蓋：骨变化は (2)，(4) とほ今同様て 一部に脂肪噵を認め，一部恃全く死骨化した骨組織片 も認める。骨破濖腔を血管，Fibrosis を示す結合幽戠肪 充たしている所見も見られる。

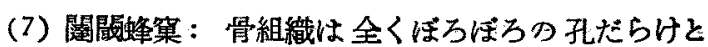
なり，骨效理が不鮮明化し，染色性が変化して通常より

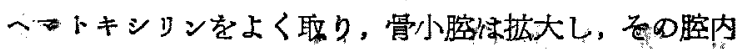

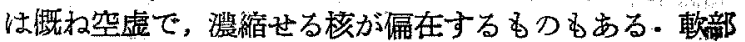

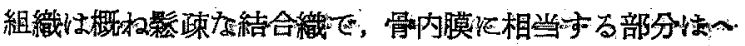
マトキシリンに溜染L，内に拉張せる血管を有し，又脂

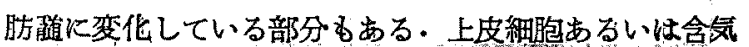
腔と考㝋られる所見は全く認められない。

斯かる所見が手術侍厄見のれる海綿骨様組織で，通常 同所見と見られる急性期つ骨破壊つ進れだもつ，慢性期 の破壊修腹の繰り返されているものと少しく趣きを異炕 している.

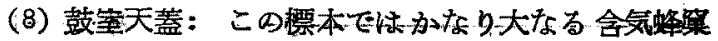

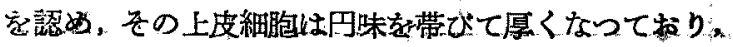
1〜数層に增殖犱厚している. 舍気膑内にはかなり細胞 成分江富んだ出物を認める・被覆上皮下組織は高底门 浮腫を呈し概ね 10 数倍江胭厚しているが，急性炎症性

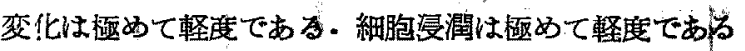

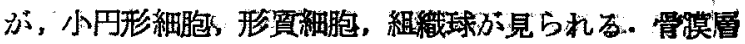




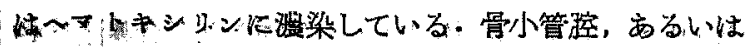

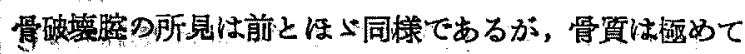
脆弱となり，手術持つ变化と思われるがばらばらになつ ひいる・一部ては極めて高度の脱灰が見られる・又一部 火は高度の死骨化が見られる。

（9）外耳道後壁：骨の多孔質化が 極めて強い，骨檤

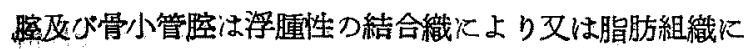
より充たされ血管腔の狭少が見られる・骨の一部は甚だ

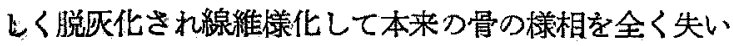

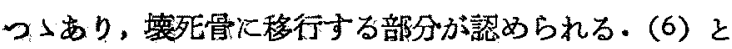
ほ心同様である。

(10) 㘶耳道底：含気蜂窂上皮細胞愔立方形で背が高 く沙り，一部では上皮下に高度の円形細胞浸潤を認め る.この上皮細胞は下鼓室の上皮細胞である．この部は 整血，多形核白血球つ浸潤がかなり見られ，急性炎症が 甚だしい，含気腔内にはかなり細胞性分儿富んた氛出物 が見られる・骨は甚たしい多孔筫化を呈し，一部では八 管ま中心として比較的新しい骨が新生されその周围は脱 死代され，一部は線維様化している. 即ち世代つ古い骨 そ比較的新しい骨とが交錯し，骨の新生破壊が線り返さ 机ている事を示している・一部代外取道皮届を認める が，かなり古い炎泟性变化を諰ぬる。

(11) 外耳道前壁：骨の新生, 破壊つ変転恃甚だし く，骨小管を中心としてあるいは管を中心として新生 した骨は恰る癌真珠腫㥞の形をしてぼろ涪ろになつてい 3. 骨内膜層恃やはり肥厚し，へマトキシリンに濃染 飞, 内胵は浮䭪及び Fibrosis が強く, 一部は脂肪䀎道と

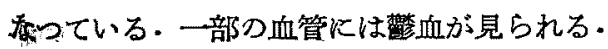

(12) 耳管外側骨壁：骨つ变性は極めて高度で脱灰化 は勘だしく，大部分つ骨が線維樣化している。骨は全く 新生治償機転に乏しい。

(13) 前蜂笨 (Kopetzky-Almour 法)：骨つ変化 は比輍的軽度で核の消失，紋理つ不鮮明化を䜅めるが， 前述のような高度の变化は認められない。

（14）錐体尖 (仁保・平野法)：側頭葉を挙上して剔 出した錐体尖を含む錐体前面骨である・変化は鼓案天蓋

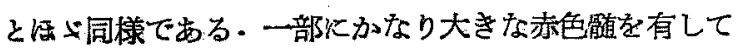
いるが又一部には脂肪䯣る見られる。

(15) 解剖学的錐体尖: 変化は鼓室天蒀, 錐体尖（仁 稆・平野法）と同様て，骨小管つ㹡大，籍眯な結合織に よる修復が著明である・

右 耳:

（1）外耳道上料：ばらばらになつた骨組織は紋理が
消失し，骨つ漹屯りが非常に悪く，薄くへマトキシリン 家とつている・こつ所見はすでに左耳で述べた如くで， 接合貿が变化し，殊儿㭙代つ異なつた骨筫を接合してい る部分が離断されている・骨小腔は摭大して和り，核は 殆ど消失をきたし，一部垡存せるものは骨小管附近に見 られ，浱籍等刀変化が認められる。骨小管膑こは Fibr

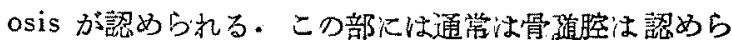
れはいつであるが，本耳では広義つ骨小管つ他见骨咀腔

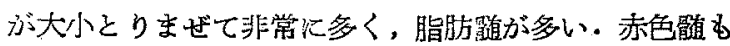
涊められる・八管も極めて数が增加している。これ等の 骨闪膜は肥厚しーマトキシリンK溜染している・急性炎 症论は殆ど認められず，造骨細胞，破骨細胞も殆ど認め られない，骨小管，八管内つ血管法周囲つ浮腫汇上り压 迫され，血管内㤸血球に乏しい。

（2）乳様洞つ外侧壁：县つ变化は（1）と大凡同様で あるが，骨組織の線維様化している部分があり，更には 脱灰化が著明で（1）上り死骨化つ程茛が強くなつてい る.骨小管腔火は浮䐺が強く，Fibrosis と共火血管は

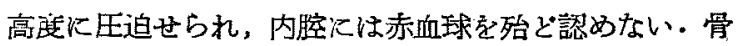

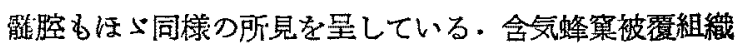
も高度の浮腫を呈し, 鹤血, 細胞浸潤は殆ど認められ

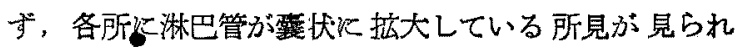
る. 厚さは通常の 20〜30 倍で，上皮細胞も円味も帯び， 背が高くなつて1〜数層俚增殖している. 含気腔内には 洷估物は認められない，通常の含気䗋兾炎では腔内の所 見，上皮下罝の変化が強いが，この関保が逆になつてい る。

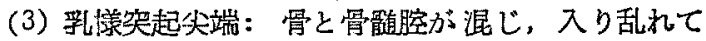

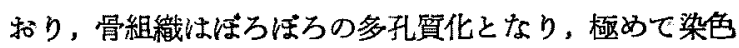
性が要く紋理は認め難く，一部は骨が線維様となつてお。 り高度の脱灭化と考它られる・骨周辺つ部分こは細胞唚 潤は柾めて軽度である。

（4）隅角蜂菓：骨組織つ染色性㵊も上く，八管内

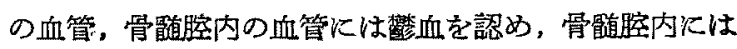
骨様組織を認める部むむる・一方には古い線維㥞化した 骨，ぼろぼろ汇多孔質化した骨も見られる，骨の脆弱化 と見做される離断新見は骨小管を中心として行われてい る傾向にある。

（5）S 状洞壁：骨の变化は（1）と同様で骨の紋理つ 不明瞕は標本全体に認められる・更に多孔筫化している 部分が混在し，核の消失が強い。骨鹃腔は非常に多数に 見られ，脂肪酭でその周辺つ一部こ器質化された部む見 られる・赤色髓は認められない。 


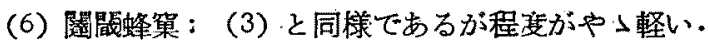

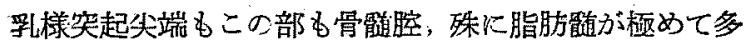
く，通常の含気蜂集になるべき部分が骨娟檫となつてい るるうに見られる。

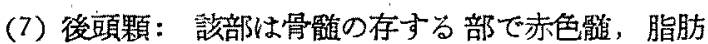
髁が多量厄存在し，その中の骨組織は薄くばやっとへマ トキシリンをとり，骨の線維㨾化が著しくなり，骨質が 碓断されている部分もあり，死骨化が最も強い部分であ

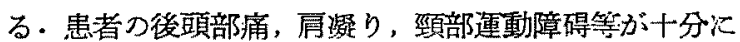
想像できる所芫である。

術後秷過：左耳手術後絶刘安静を取らしめた。手術 後の观置は成らべく最小限に止め，5 日間は耳内，耳後 邻に抗生斉老注入するに止め，6日目に創内よりの涔出 物が多くなるに及び，耳後創のガーゼ片を毎日小量づ〉 报き去つた・術後の聴力は自覚的には著変なく，本人は 耳内ガーゼのためかわからないと云つていた・左耳術後 15 日目に耳内より開空部に当て〉いたセロフアンを取 り除き，移植皮㭊の固葿を確かめた・左耳を手術して からも安静につとめさせ，18日間に及んだ。右耳は術 要 4 日程は聴力が術直後つ状態に保たれていたが，5日 目より滲出液のため急激に低下した。患者つ不安（聞え るよらになるかどうかつ）は非常に强かつたか，その後 創内よりの出液の少なくなるにつれ，徐くに上戒して 行つた。この間耳鳴と，眩最の而者に対して，7\%重曹
水 $60 \mathrm{cc}$ にビタミン $\mathrm{B}_{1} 100 \mathrm{mg}$ を加えた混合静注を 40 回行つた。右耳手術後 33 日目には約 $4.5 \mathrm{~m}$ 離九て少し 大きな声を出すと返事をするようになり，左耳は術後 48 日目に反対耳に Noise 70 字かけ約 $1.5 \mathrm{~m}$ て店答す. 右耳術後36日目にラジオを聞かせた所, 約 $3 \mathrm{~m}$ 離れ, 音量大にして音楽つリズム等が良く聞觉；女性アナッン サーの話がかかる. 左耳術後61 日目には創内の上皮化 せる部分が箱張してき，步行も慣れたので退院せしめ。 た.左耳街後 87 日目には頑固でつた耳漹が非常に小さ くなり聴力が更に上冢したと云つていた。術後半年目に 来院した際には，右耳は 2〜3m からの普通の会話には。 殆ど不自由なく聴き取れ，左耳は耳の正面からは話す声 が聞えるので，勒㔙できるようになつたと喜んでいた。 現在は術後 2 年になるが補聴器る使用せずに元つ会社に 勤務している (図 2 参昭).

第 1 例左耳総括：本耳の 鼓膜所見より誩断すれば中 耳炎残貽症，あるいは慢性中耳加答児であり，そんなに 聞えない訳はないと云われる鼓膜である・オージオグラ

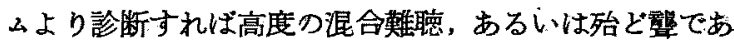
る・レ線より䛦断すれば慢性側頭骨骨䯣炎である。その 組織学的所見より診断すればレ線学的診断が正しい，鼓 膜所見とオージオダラムのみで神経難㯖による璧で片 付けられてしま5。

この高度難聴の発生を考察するにレ線で马状隆起が錐 体，乳様突起部上陵の上に㔖出している。この所見は側 頭骨つ発生学を考えれば直ち

Name. 国 $O \neq 0$ Age 43 .

F.

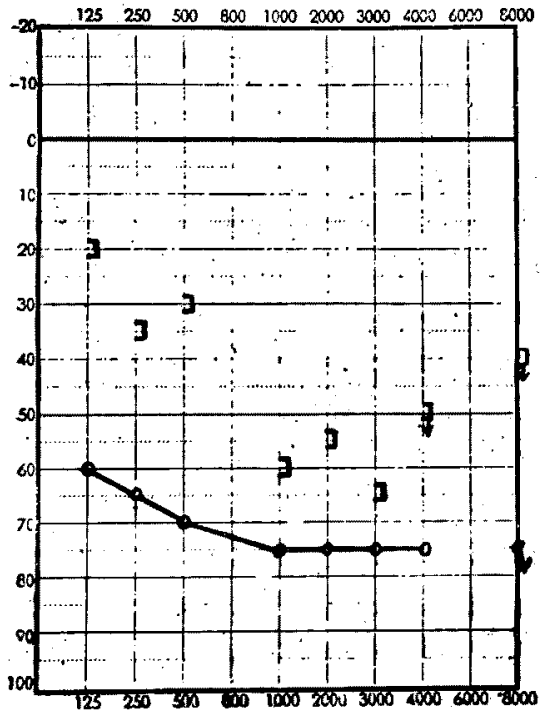

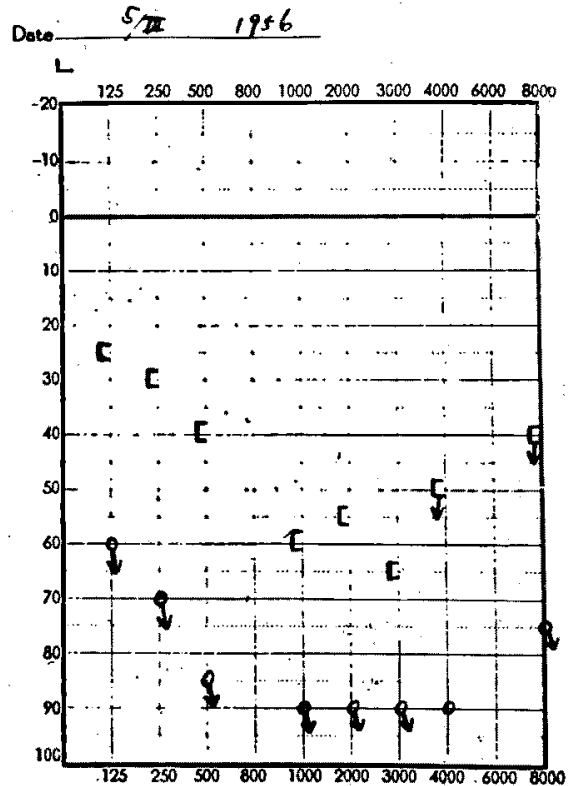

に了解される・即ら三半規管 は内耳の一部であるから側頭 骨より先炕完成される・従つ て乳幼坚期にある程度以上の 骨病変を伴つた所䜊広義の中 耳炎濰患すると，殊にとれ が放置，不適当な治噔あるい はアデノイド増殖，慢性副鼻 腔炎等により経過が遷延する と，鼓膜所見では治癒したよ

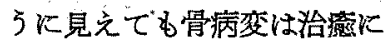
趣かす，その後う乳様突起部 の発育は正常の発育を遂け得 ず，征つて上半規管加上稜上 に笑出する所見を呈し，手衡 学的には斜めな外耳道後壁。 
中頍蓋旊底の低下，S 状洞の前方位をとる．更に所謂中

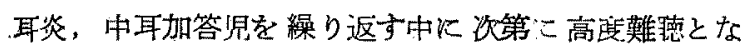
的，何時とはなして䖮牛も侵されて本耳か如くになつて 儿2 5 。

本耳刀組織学的所見を総括さるに最む著明なつは骨病 湾である・而尚骨膜層あるいは骨内膜層より造骨細胞の 活動に上る骨新生が全く見られない，又破骨細胞火上る 嗗破壊も殆ど見られない，而も骨つ変性は甚たしく，正 常つ骨組織は全く見られない.即ち核の濃䋐, 偏在, 消 失，更には骨小腔つ拡大，甚だしいのは2〜3の骨小腔 が融合し，勿論骨細管も破壊せられ一架洞をなしている 所見も見られる・骨の染色性は比較的時代つ新しい骨は ェォジンをよくとり，古く变性の甚だしいものはへ、ト シキリンをとり，異常な紋理が著明となり，死骨化の䓕 ホしいるのは両者の染色性が悪くなる・ワ染色でもほら゙ 洞様である・斯かる時代，変性の種々雑多つ階梯のもの が入り乱れて存在している. 即ち吉田の云う Anbau, Umbau, Abbau が行われた事を示している.

脱灰は石灰程類が溶解して骨焃組織となり，続いて固有 組織つ吸收崩壊をきたすむのて，破骨細胞つ形成を伴わ 朴以。

本耳の脱灰化は骨の染色は徳くなり，赦理は全く不鮮 明となり，あるいは核の消失せる骨小腔が㹡大し，更に 周国の骨細管も吸収せられ，更に2〜3の骨小腔汸融合

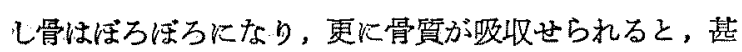
だしい場合は骨は線維様化（附図 10，外耳道前壁，附図 A1., 耳管外側壁) する. 㕛骨様組織化 (附図 8, 外耳道後 壁)する。

次に骨組織がばらばらになつている所見に就いて述べ 就う.これは横浜医大病理の吉村教授に同つたら標本作 製的に生じた所見ではない由である・従つて骨組織の離 断は手術時，標本採取封の機㧴的刺战见因るるのと考党 られる。

骨組織つ離断部を詳細に見ると骨变性の甚だしい部位 K多い，附図 6, 闒閾蜂黛の右方では变性つ強い骨の中 に八管を中心として時代の新しい骨が生じ，両者の境界 が明らかに離断されている・即ち時代つ新しいるのと古 いものとの間の接合質は弱い上うである. 又附図 10, 外 耳道前壁では概小骨は脱灰化が強く，線維様化となり， 中に 4 個の八管を中心得生管塊があり，両者の境界が 離断されている。

次に盈の営盖，体夜循環を司る腔内を見るに，大なる るのは骨髄腔となり，脂肪䯣むるいは赤色顝を含んでい
る・中位つもつは多くは中心血管犮し，その周团は 浮埂を是し，Fibrosis を見る・しかしながら炎症性細 胞浸潤は梄めて少ないか，あるい性全く認められない。 中心の血管腔内炕赤血球訬なく，周囲つ浮腫により 圧迫せられている所見である・小なるものは明らかて八 管つ状態を呈している・しかしこの小管も以前にあった 八管ではなく，長年月間に繰り返された治癒機轱即ち骨 増殖がそつ血管を中心として行われた事を示している。

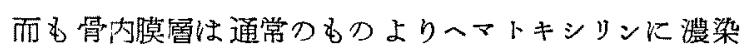
し，血管周囲火同様に Fibrosis の認められるものもあ 子。.

これ等つ間質に相当する腔つ発生を考慮するに，第 1 に考えられるのは骨破罱腔が肉芽により修復せられて次 第见斯かる所見を呈する場合である・第2 は含気腔の炎 症が高度で上皮細胞が買减された場合に斯かつる所見を 呈する場合がある・本耳の隅角蜂窠住認められたが，中 心见小含気腔つ上皮細胞见团まれた小腔つ存在する場合 も出る・第了は小骨髄腔が破壊されて斯かる所見を呈す る場合がある・第 4 は彷来称えられたものとは別つ骨破 壊型式で，骨小腔の拡大が甚だしく，2〜3の骨小腔が 周囲の骨細管と共に吸収せられて空洞を形成し，骨が注 ろぼろになつている所見がある。この空洞に肉芽が侵入 すればその終結の姿は斯かる所見を呈する事もあり得 る. 穿孔管 (Volkmann 管) 形成々類似してい.

元来瀜平骨には長管骨比比し八管は少ない。これは骨 娟腔，周囲骨膜より営荃されつばよいからである・本耳 では斯かる小管腔は急性炎時に比して遥かに多いこれ は長年月間破壊治癒が繰り返されるためには，通常の側 頭骨より遥が大量のエネルギ一を必要とするためと考

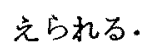

次に含気蜂窠炎の所見では上鼓室にかなり大きいもつ が見られる.含気蜂巢被覆組織も急性炎症状にそしく， 浮腌を主としている。これはその鼓膜所見よりすれば上 鼓室も洽澉と考克られる所見であるが，本耳の如く骨病 変が一度高度となつた後は含気腟被覆組織も完全な正常 の状態には戻る事ができず，上皮細胞る文正常の内被細 胞様扁平上皮に戻る事はできないで，背が高く，所によ り数層になつている。骨及び被覆組織にはある程度の関 連性が存在している.

上鼓室を除いては隅伤蜂集に線維性瘢餈状となつた組 織つ中に細長い残存小蜂窠が見られる。

即ら鼓室，上鼓室を除いては乳様突起，外耳道，錐体

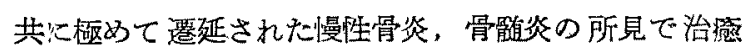




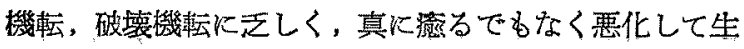
命を危險に曝すでもなく長年月を経過し，その間に次第 亿伝音系，感音柔も障碍せられて斯かる高度難聴々なつ てしまつたものと考觉る。

第 1 例右耳稜括：本耳も鼓膜所見より猃断すれば慢 性中耳加答胃，オージォグラムより診断すれば高度の混 合難聴，レ線より診断すれば慢性側頭骨骨䯣炎であり， その組織学的所見よりすれぱレ線学的䛦断が正しい。

鼓膜所見とオージオグラムのみよりすれば高度の神経 難聴で片付けられてしま 5 。

手術所見よりすれば術中あるいは神経難聴であつたつ ではないかとの心配多強からたが，庝眼的所湜の割炕骨 がひどく脆弱で岕った。

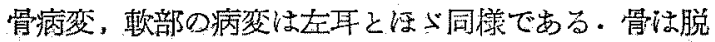
政化のために染色性が極めて贯人，核は消失しているす のが多く，骨小腔つ拡大，紋理の不鮮明，更に甚だしい

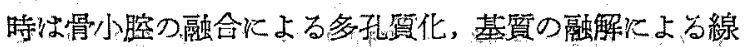
維様化等が認められる・骨の接合凟の変化により手術時 の機㭜的刺皒によって骨がばらばらになつている.骨の 新しい時代と古い時代のものとの境が最も離断され易 い. 又層板がばらばらになっている所むある。

軟部組織では含気蜂窠炎の像は乳橡洞の外側壁炕見ら れたのみである.上皮は円味を帯びてや゙背が高く、1 〜数層になっている.

上皮下比極めて厚い浮蕾家主徽候とする層があり， 骨膜層まで続いている・魏血子細胞浸㵎も殆ど認められ ず，稀以小队形細胞を見るの多でる。これは土台の骨 病変があまりにひど過ぎるがために，斯かる变化によっ て骨病变との均衡を保っていると考文られる・通常の慢 性急性増悪の所見々は区刘である・手術時に後方より見 た上鼓公の所見もは心゙同梂であつた点よりして，上鼓

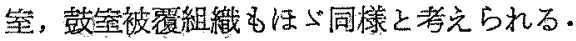

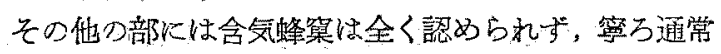
含気蜂笨の存在している部な骨䯣室となつている・即ち 斯かる管病变の上以は通常の含気䗋窂被楊組織は再生し 得ず，文発充もできず，恰も上顎洞の如き沿潦機転をと つている.八管も通常の骨組織営養するためのるのて はなく，县を修復するためにとの数が極めて多くなつて いる.中間型の骨小管々総括した腔は左耳の所芫々ほよ゙ 同梯である・大型のるのは総て骨䯣，多くは脂肪䯣它有 している。

後頭顆の所見は與味が梁い，軟部は狭義の骨敷炎であ り，乏の閶に骨梁の骨が高度火变性し，又死骨化してい，

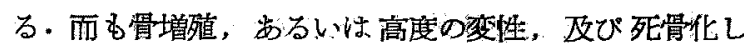
た，個体火対して異物的存在の骨組穖を破骨細胞に上り 破壞して運び去ろうとする所見が見られない点である. 期かる骨を手術に上り除去すると患者は肩凝り，首の張 るのがよくなる。

本耳屯左耳同様に含気䗋菒炎は治签の傾向にあるが， 高度の骨病変のために側頭骨病变珪瘾るでもなく，踰ら

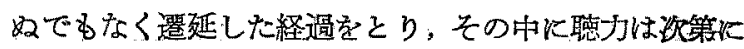
低下してしまった。

症、例 2

者患：大○美○子. 7 才.

初唁：昭和 30 年 2 月 8 日

主訴: 留吗

家族歴：記載すべき事は㦄い。

既往歷，現病歴：生後 1 年 2 力月の時雨側頭骨合気

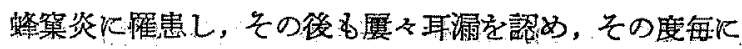

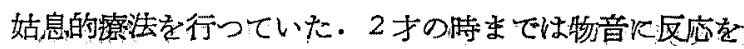
示していたが，濑次反店示さなくなり，5才の㭙には

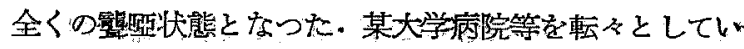

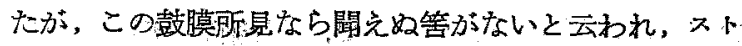
マイによるるのだと云われ，又精神薄弱罗であるうとも 云われて，止むなく憼暨学校進学せしめたものである。

初部時耳科的所見：両耳共に鼓膜以は穿孔がないが，

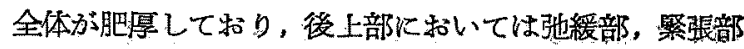

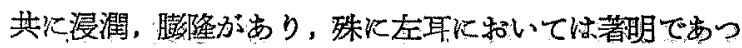
た・光雓は消失して括り，鼓室には相当の炎鿊性の変化 の存在が想像されたが，発赫な゙ないで現在は小康を保 つていると考觉らていたらしい。

Stenvers レ線写真所見：右耳の乳樣突起は尖端学含 め一様に本鲜明である・乳様洞附近及び迷路周囲には小， 蜂窠群らしきすが謬められるが，これ等白辺縁が不鮮 明となつている・乳様突起天蒀の骨上陵は強く下降して

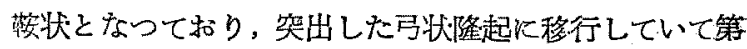
1 例同榚に危険性側頭骨と考えられた。

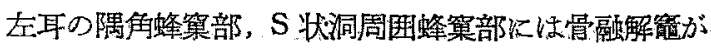
あり，迷路周囲及び学様突起尖端は不鮮明である：蜛牛

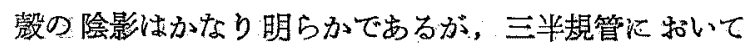
は，辺縁が潘けて打り，はつきりとは確加めら机ない。 錐体尖は捀窠らしきるが認められす骨融解像を呈して いる.乳様突起上陵の鞍状化は右側と同様であり，雨耳 比較すると左耳のレ線像の変化が強い。

聴力検查：気導楧查ては両耳共に 全然区応を示さな

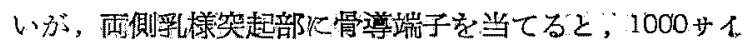


クル，2000 サイクルでは，60机 の最夫值て頻りに眼を 動かしたり変な声を出していた＼cjkstart笛の音や小石を詰めた 空鑵を振つて音を出して検査したが，これには反応を示 さなからた。

レ線上より骨病変の存在が考えられ，鼓膜所見との両 者より左側が病変の程度も大と思われた，これ等を取り 除く事が先決問題なので下記の如き手術を行つた。

昭和 30 年 2 月 15 日庄側頭骨炎根治手術及び三うの半 規管の Labyrinthektomie，昭和 30 年 3 月 9 日右保存 的側頭骨炎根治手術及び水平半規管の Labyrinthektomie を行った.

左耳手術所見：耳後切開により入るに，乳様突起は 極的高度の慢性乳様突起炎急性增悪の所見を呈し，乳

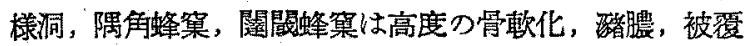
組織の肉芽様肥厚を呈していた・上鼓室，鼓室もほ心゙同 様で，橋部は全く死骨様となつていた・錐体前蜂巢列る 骨变化山極めて強く，骨軟化，一部㱠膿を呈していた。

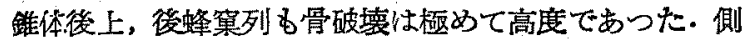
頭葉を挙上し，錐体前面を仁保・平野法により除去する に，乳樣突起天蓋，鼓室天蓋恮く死骨化し，錐体尖上 部す骨が脆くなつていた・我平半規管、後半規管はや〉 黄色を呈し, 光沢悪く，初ぬ水平半規管を切除するも眩 最法起らず,内腔も全く認められなかつた・後半規管も 同様であった・上半規管も同様であるので, 弓状隆起を 除去，上方より鳌除した・䄪半分整除した所眩最が起 り，啳内方の脚より内淋巴液の漏出を認めたつで手術を 中止した.

右耳手術所見：左耳に比べてや〉急性増悪の所見が

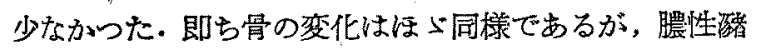

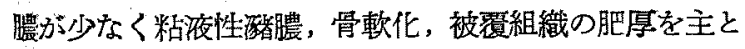
するるのであつた．上鼓室，椐部つ所見がや〉よいの で, 鼓膜, 耳小骨江保存し, 錐体後上, 後, 後下蜂杲列 は可及的に清掃した. 唯水平半規管の前 $1 / 3$ の部に黒褐 色の瘦孔を認めたつで，水平半規管を Schichtweise に 削除し; 更に瘦孔を細小鋭匙で慎重に搔爬した・後方は 半規管が久除していたので，前万に進み，膨大部つ少し 手前で眩最が起り，比較的奇麗な内腔を認めたので術を アした.

病理組織学的所見：手術時に採取した側頭骨各部よ りの組織片を軟部と共にッエロイジン包埋し，へ・土重 染色, 奴びワ染色により検索した結果は下記の如くであ る.

左 耳:

（1）䄻様洞の外側壁：骨の変化は極めて強く，骨つ

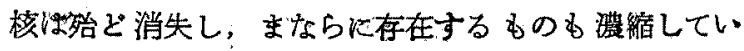
る・骨の政理は不明となつている部分が多く，この骨組 織吸収が起つている。骨小管内には浮腄，Fibrosis があり血管の閉塞が見られる．管腔内よりの骨の吸収や 新生は認められない.顿部組織よりの骨の吸収は諸所に 羿められ，又諸所の骨小管の骨壁には造骨細胞つ並列が あるが骨㙕殖は認められない，骨壁の周辺部においては 変性の極めて強い部分もある.

（2）乳様突起尖端：骨の核の消失が強く，效理の錯 綜も見られ，変性が著明であり，周团の骨䯕腔より吸収 及び増殖が行われている・骨小管胵はいずれる浮腫及び Fibrosis があり，内腔は縮小し，周辺に対してはいら れも何の变化も不ぼしていない，骨髄膑は非常飞多く見 られ骨と入り組んでいるが，いつれも細胞成分が増加 し，周辺《は骨破壊、吸收あるい、造骨細胞つ並列が見 られ器質化された部分も見られる・文相当に線維性とな った結合織る見ら机明らかな骨䯣炎の所見を呈してい る.更に軟部組織の中には高度に死骨化した遊離骨片る 見られる。

（3）隅陆蜂贯：骨小管腔法不整形に拉大し Fibrosis む著明となつている、これ等は骨破塄腔つ治㴰の途上 にあるむのと考えられる・骨䯣腟においてはやはり結合 織つ増殖及び細胞成分つ増加が見られ，骨鹃连能法失わ れつつある。骨は紋理が錯綜し，諸所に見られる接合線 が乱れており，骨小管，骨咀腔よりの骨の新生像及び軟 部結合織よりの甯状财取のため，更に複雑化している・ 骨の変性は相当に高度で，一部分ではあるが，骨が楾維 様化している所もある・一個所相当に大なる骨破壊腔つ 中に2〜数㥜か円味を带びた上皮細胞に囲まれた貯があ る・これは含気腟つ名残りであり，軟部は上皮下の血管 に富める層，骨膜層等全く区别なく肥厚し，而もその 中に2個つ小骨髄腔ができている・與味深い所見であ る。

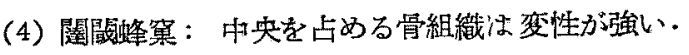
この骨組織梳次第に吸収を蒙り, 周辺より消失縮小さ れ，接合線勇境䎲して年代の新しい骨に変つて行き，更 にこれが変性に陥つて吸収され，新しい增殖骨に変る という改造つ繰り返しが続いている・最も時代か新しい 骨に机いて子核の消失が見られ，又濃縮している部分る 見られる。これ等を取り巻く軟部組織忧，完全な慢性含 短蜂笨炎の像を呈し，1＼cjkstart数層の背の高くなつた上皮細 胞，上皮下の浮腫，上皮下㬝の器質化，軽度の絹胞浸 潤，骨膜層の増殖，所により造肙細胞つ並列を見る等つ 
所見を呈している・しかし第1例の如く骨組織がばらば らになつたら; 又多孔韻化，線維様化等の所見はない。

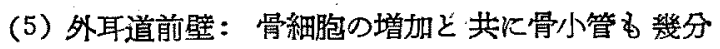
多い. 本例の骨小管腔力大部分は八管内壁より骨破㯖が 起り，管腔は拉大され，その内腔火恄合織細胞が堌殖 し，管壁はーマトキシリンに惯染している。骨質す比較 的一マトキシリンを余計に取つている部がある。骨小管 腔あるいは骨譄道腔内には造骨細胞の並列る見られ，管腔 周囲には時代の新しい骨が見られる。この所見は骨破壞 腔が血管を中心とする治癒機転により縮小せられ，内腔 は結合織による器質化が起つてきた事を示している。こ の世代の新しい骨はへマトキシリンによく染なつて管腔 周辺にリング状をなしている，骨の吸収所見に見られ

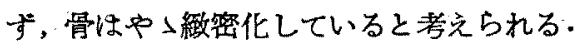

（6）弓状隆起：骨は核が大部分消失し，僅かに一部 分㸺縮せる核が存在している・この部分つ骨壁には一 層の造骨細胞の並列があり, その周辺軟部組織には結合 織が少しく認められる・骨の紋理は骨小管を中心にして 割合規則正しいのであるが，骨小管腔内の Fibrosis の 強いるの程乱れが強く，又骨小管を遠さかるにつれて敉 理子不明瞭となつている・骨の辺縁に特いて空状吸収が 見られ，㕛鋸雪忋をなした接合線が数条接近して走つて

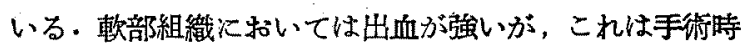
の出血と考㝋られ.

（7）上半規管附近：この標本は側頭骨炎根治手術を 完了後に先ず弓状隆起を除去, 更に内外淋巴腔が開放さ れないので上半規管を層文層と上方より監除し，遂に上 半規管点約半分整除し，その内側の脚から淋巴液の流出 した時の標本である。

骨仕非常に維密で，叔理は不鮮明ではあるが僅かに認 められる・核は消失したるのもあるが, 濃縮, 偏在, 又 比較的よいるのるある・しかしこの骨塊の周团で肉芽の 中にある小骨片は骨の変性は滛か強く，死骨様となつ ているるのが多い. 含気蜂窠は周辺に小なるるのが 2 個

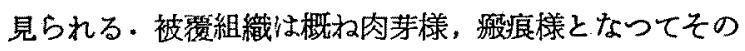
中に背の高い2〜3 層の上皮細胞に团まれた細長い腔を なしている・その他炕6個の骨小管が見られる・その中 1 個公八管と思われ，中心つ血管には赤血球の充満が見 られるが; その他つものは1〜3個の八管から骨融解原 より骨融解蹗ができて慢性化し，Fibrosis が現れたも のと考えられる・これ等の胵の周辺认は造骨細胞の亚列 が見られる・その他に 1 個か一見含気腔と見られる所見 がある・内腔は円形，骨胵はや」横に長いが，内腔の上
皮様に見える細胞は合気蜂笨つ被覆上皮でない点上り上 半規管の内淋巴胵と考える・外淋巴胵は肉芽により奆た されているが，一部附近つ骨破壊腔に連絡している・肉 芽組織には結合織細胞, 小円形細胞, 組織球がかなり茨 められ，乙の他網状をなした線維性組織が見られる。含

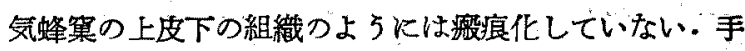
術時にこの内淋巴腔が開放されて瞙暈が起きたものと考 えられる。な和この内耳炎は水平半規管，後半規管の内 腟か欠除していた点上りしてる，相当に古いるのと考え られる。

（8）錐体尖 (仁保・平野法)：過去に和ける骨の吸収, 増殖が強く行われた事を物語り，赦理は種々に錯綜して いる部分が多く，これ等に断裂した多数の接合楾が見ら れる・骨の核は消失しているものが多く，消失しないま です澧縮している：この骨に軟部組織よりの简状吸収が 見られ，更䌿增殖による類骨組織の附加している所が 随所に見られる・骨小管腔厄おいては骨の増殖所見が見 られ，やはり管腔う縮小が行われている・しが新生骨 においても，简状吸収が現われている部分が僅かながら 誌められる。骨小管内の Fibrosis はやはり強く，血管 は縮小して括り，細胞浸潤子認められる.骨を取り囲さ 軟部組織の中には高度の死骨化した骨片が散在している 部すある・組織片の中には 2 個の含気蜂笨が見られ，被

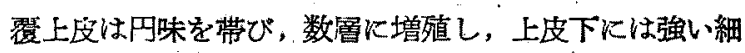

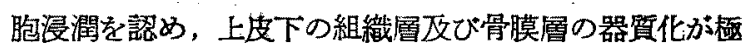
めて強く，通常の10 数倍に肥厚している・大なる骨檤 腔にも結合織による器質化が諗められる。

\section{右 耳:}

（1）外耳道上柬：骨刀脆弱化は変性つ強いものにお いて影著であり，線維傹となつてばらばらになつている 所るる.しかし紋理が比較的て明らかで规則的の所る あるが，やはり核は漕縮して扣り総じて変性の傾向が強 い. 骨壁の表面に一部造骨細胞子見受けられるがその周 刃つ骨の増殖は少ない，軟部組織は概れる骨睢腔であるが 通常は骨䯣組織が殆ど見られない部分である。この骨监 腔には浮堙があり表面には Fibrosis 方軽度に認められ る・これは手術時外耳道上棘の直ぐ後に褐色つ点が点々 と見られた所見である。

（2）乳様洞の外側壁：骨注比較的によく染色されて いるが比較的へマトキシリンをよく取つている・核の濃 縮，消失，紋理の不解明，乱れを認め，含気蜂集炎は比

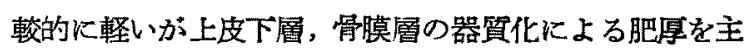
勰める。 


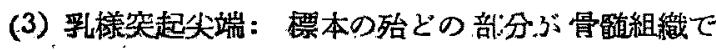
細胞成分泣から增加しているようである・小骨片が周 囲に見られるが，核の消失，䎦理つ不閹化等俚あるが 破壊，吸収，堌殖等は不明で岕る。

（4）乳樣洞：骨の变性は強く，染色性は極めて悪く。 骨の核は消失が目立つ。核の鳌綰厂至不整形，偏在する ものも見られる・骨周囲軟部組織，即ち合気蜂突や骨小 管腔上りの骨の秴状吸収のみが行われている部分は少な く，一度吸収され，再び堌殖が行われて，二度も三度も 躁り返している所見である・斯かる骨の变化のため心，

骨質中には接合線の断裂した走行が数多く見られる・骨 の核の消失している部分では骨組織つ断裂が多く見ら れ，骨基貿の脆弱性を表わしている. 又多孔質化され䋌 理が不明瞭となっている部分子見られる・骨小管腔は一

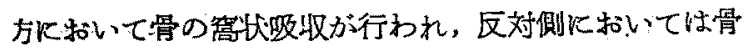
の增殖が繰り返し行われて，次第に吸収方向に位置の移 動を行い，变形，不整形文なしている所見もある・骨小 管控内には Fibrosis の形成が強く，殆ど管腔内が埋め られた所見である・更に浮腫も加わり，血管の区迫が甚 たしい，軟部組織，主に合気腔被亚組織ておいては，炎 症性変化は比較的軽く，上皮下つ組織つ浮腫主主徽候々 し.'軽度つ細胞浸潤も見られる・而して與味梁い事は， 土合の学の变化の少ない所は比較的被洎組織の变化子軽 く、楩凹部，骨の悪い所は肥厚が強い.内腔の出物は 極めて僅かで，骨病变が治瘾しないために骨膜層，上波 下の組織層の浮腫が取れず，含気蜂集炎の治㽷が遷延さ れている感が深い。

（5）隅而蜂笨：骨の核の消失が著明であり，骨小腔 の拡大が見られる・骨の数理証不明瞭となつている部分 が多く，吸収，新生等の所見は著明てはない、軟部組織 には僅か、線維性結合織が現れておす，細胞浸潤が認め られる. 又軽度の浮腫るある。

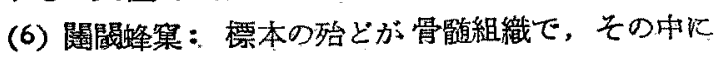
死骨化した骨片が諸所に見られる・含気蜂集の発育が雳 く，上線所見の正しい事がうから゙われる。

(7) 後蜂穼列 (山下法)：骨組織は変化の比較的飞軽 いるのと，離断されて死骨化した骨の二様がある・含気

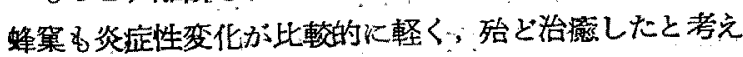
られるすのと，一万には骨膜層，上皮下層が相当器質化 され、中に小なる2〜3 層の円味を带びた上皮細胞火团 まれた小腔となったものとの二様がある・骨小管内つ Fibrosis，内壁に造骨細胞の並列を見るものもある・骨 破壊，增殖見られ尚:
（8）後下䗋案列（Kramm 法)：概小骨の変化は中 等度である・周辺つばらばらつ小骨片には变化の強いも

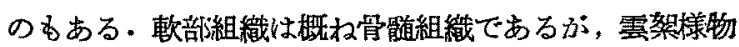
質が析出され，細胞浸潤，巨大細胞も見られる。

術後経過：左耳術後4日目に左耳上り䄪 $1.5 \mathrm{~m}$ 離れ て，小石を詰めた空缶ね上下振つてガラガラと音を出

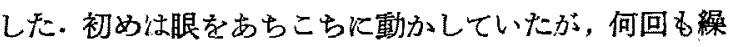
り返す中にアラアラという似たような音を出した。これ に勢い学得て空缶家吅いてかンカンと音を出したが，こ れはわからないよ5である・5日目に笛のビーピーとい う音を出したらビーと答えたので聞光ている事がはつき

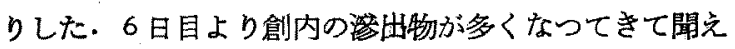
なくなつたようである・側頭骨资根治手術を行つた耳で は，やはり1週目位加ら聴力は目立つて落ちるよ5であ る.そして䄪 3 週間 1 1 月位経て, 創内の上皮下が進 むと共徐々に上界して行くのである。

術後の耳内取び耳後創内のガーゼ交換はなるへく行わ ない方がよいてでるだけ長くお゙いて自然の治瘉機転に 任せればよいのであるぶ，Drainage としてのガーゼ片 は異物であるので創内の反庯が強くなるもので, 出出物 が多くなり，止むを得ず5〜7日目から报き出して行く

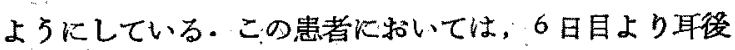
創からのガーゼを約 $5 \mathrm{~cm}$ 位づ取り去り，術後 2 週間 目には耳後創は閉ぢてしまつて，それ以後は耳内よりの カ゚ーゼ交換によつた・左耳術後22日目に右耳つ手術を

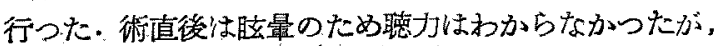
翌日より単調な音（即ち前述のがラガラ，かンカン，ビ 一,手を吅いてポンポン)には約，1〜1.5m 位でよく聞 えるよ5で，盛んに似た音を云っていた：右耳術後 14 日目よりラジオの音樂を大きくして耳許で聞かせるよう にした・初めは戸惑つていたが，次第化調子を覚えて3 日目よりリズムに合せて身体を振り出し，それぶよくり ズムに乗るようになつた．左耳は術後 42 日目には完全 上皮化し，右耳は街後30日目上り通気加鼓膜いッサー ジを開始した．鼓膜の病的症状は全く消失し，光錐も現 われてきた・その後オーヂ・チニーブねつけて，簡単な 言葉やラジオを聞かせるように努め，なるべく耼象 際の音を覚光させるよ5に努力した. 左耳術後了力月目 には数字の1からてまでの軓音を覚光、ラジオではアナ ムンサーの男女の区別をするようになつた・どうしてる 右耳の方が聴力がよいのでオーデ・テニーブは右つ方 に付けて聞き，術後1年目汇は「お父さん」「お梅さん」

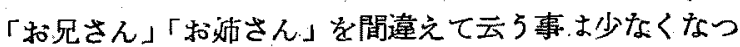




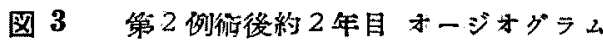

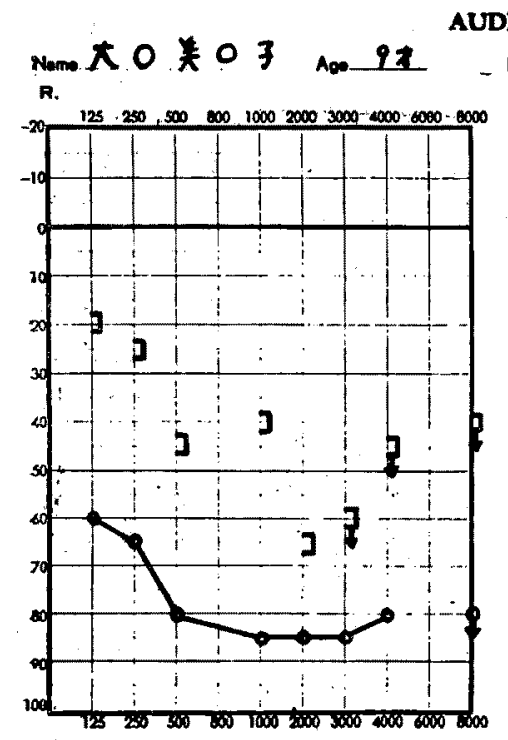

AUDIOGRAM

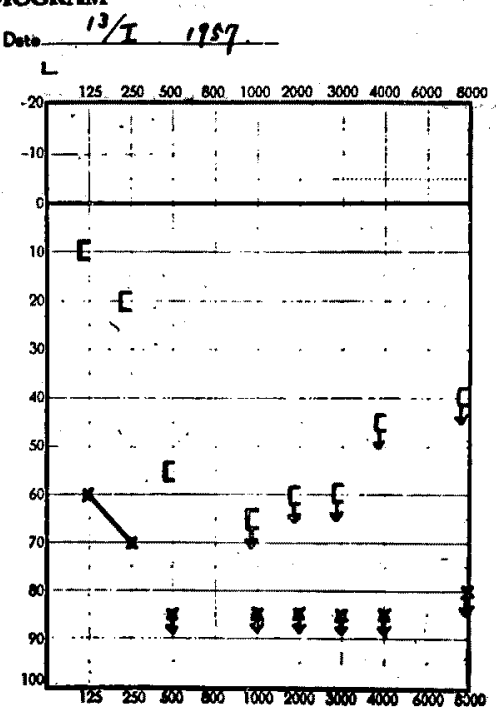

の実䟢の側頭骨骨酭炎のためK，正常 な含気蜂集つ発弆が阻碍された所見て ある・

更に左三半規管は影像がばけていて 手術化より水平，後半規管内臆刀久 除, 上半規管の内方脚の中位で初めて 内耳淋巴液の流出，喵最を認めた。

手術に持いては，左恃側頭盈炎根治

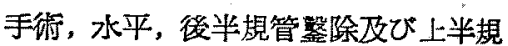

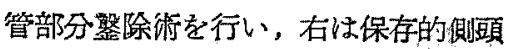
骨炎根治手術＋水平半規管度孔瀷他術 老行つた。

後者の術式は，現在流行の耳硬化症 に対する開空術つ術式を受け入れた耳 内手術術式より，遥が勝るるのであ る・本手術てい外耳道, 鼓膜, 耳小盈 連鎖のいつれにも手術的侵䫓を加えてないからである。

組織学的所見では第 1 例よりは适かて軽い，骨細胞の 核の濃縮, 偏在, 消失, 骨小膑つ㹡大, 紋理の不鮮明化 を示し，るるいは骨の破壞，吸収，增殖，即ち Anbau， Umbau, Abbau を繗り返した，時代つ新しい骨，古い 㓏，これ等の接合楾が色々の不定形な模样を現した所 見が見られる.更に甚だしい部では骨小腔つ扰大，融合 による骨の多孔質化，文骨の接合質が变化し，䀡弱とな り、ばらばらになつた所見も見られた。

しかし第 1 例に比し造骨細胞の出現，骨様組織の H 現，破骨稩胞の出現等の異物を運び去り，又修復せんと する譏転は大部強いだが急性期，覀急性期のるのに比 しては遥かに鸧い。

広義つ骨小管に括いて屾，第1例之同様に，浮腯， Fibrosis が見られるが，その中心つ血管の蒩血の度る

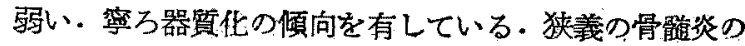

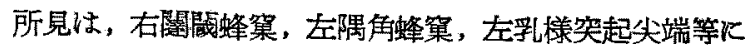
見ら九る。

含気蜂穼炎の所見は，左上半規管の附近，在履閏㛔 菓，左錐体尖，左拜様洞，左乳様洞の外側壁等に見られ るが; 炎症性变化は左錐体尖のものが最も強い、これは 錐体蜂窂炎，錐体炎が今るな挟義の中耳资の合併症の 如くに考光られている傾向があるが，興昧梁い所見であ 名.

次に骨組織，その上の骨膜層，上皮下の組織，上皮屠

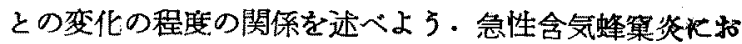




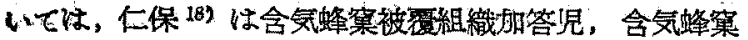

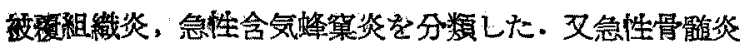

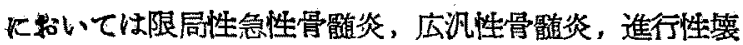
死性骨的道炎を分類した・慢性症においてはこれ等の治㽷

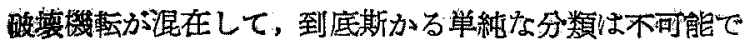
ある. しかし病的の骨の上《は正常な骨膜層，上皮下 首、上皮層は存在し得ない. 又これ等の病变の相関関俰 は概社平衡状熊を保つている事が多いが，急性期の上う な訳には行かないこのようになつて平衡関係の保たれ た状態が慢性であり，その平衡関係の破れた場合が急性 增恶である・本例に打いては第 1 例よりはこの平衡関係 はよいが，やはり骨病变が含気蜂窠炎の治痖を妨げてい 岁洘充られる。

裂暨の発生儿就いては，骨病变も相当な役目をしてい るように考えられるが，殆ど完全な㿼となつた直接的な 原因は内耳炎仁あるよう汇考党られる。

本例儿対して流行であったストマイよるるのであろ うとの医師の一言は，非常に大きな悪影響を及ぼするの でる。，広義の中耳炎，側頭骨炎を除外してからでなけ 北代，仇户䟱か儿医師が口にすべき言葉ではない。

症例 3

患者：上○大○郎. 32 才. $。$. 農

初晾：昭和31 年 8 月 23 日

主訴：敬及び両側耳漏

家矤歴：特記すべき事はない。

既往歴，現病歴：4 寸の 時，麻蛙後画側耳漏となり， 附近に尃門医がないので他科 の医師つ治療を受けていた。

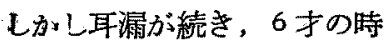
に初的専門涌院加㞠を 受けたという・難聴は次第に 強くなっていらたが，何とか 話ができで学珓に入学し た. 小学校 1 年刀頃, 天長節 等できく立つていると，瞱最 が起り嘔気がした７才の時 に法阴桃摘出術を受けたが， その後難聴は高度となり，発 音が不明瞭となってしまつ た. 耳漏も続いているので， 転くとして通院西潦を受け12 キをで行った.だが耳漏は消
失しなかつた１3才の㭙，耳内よりの手術をしないと 駡目だが未だ小さいから我慢できないたろう・大きくな つてからと言放れだ゙，戦時中の事とて手術の時期老失

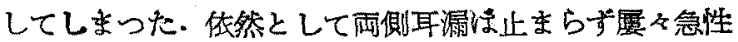

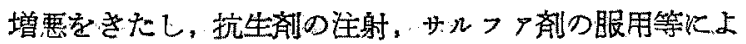
り，一眿の間炕合せ程度の治療を受け，両側の耳漏は自

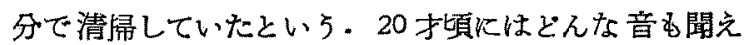

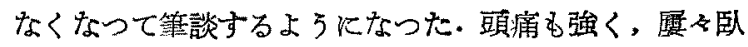
床しなけ札ばならなからた程である。しかし耳鳴灶は気 付かない，䁙最は小学校在学中心比べて次第化回数が少 なくなり，現在は年に 3〜4回位である。

初喰耳和的所見：右鼓膜緊張部は全穿孔を呈し，

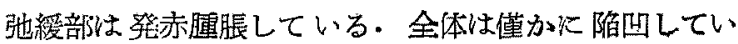
る・穿孔部より見られる鼓空内部粘莫は発赤腫脹が強い が，膿汁江認められず乾燥している・左鼓膜も同様に緊

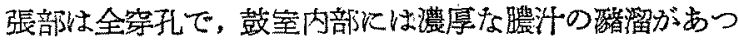
て穿孔部より外耳道に流出して和り，鼓室内粘膜は発亦 腄掁が右耳儿比べ更に著明である。この膿汁内には仮珄

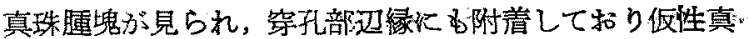
珠腫生慢性側頭骨炎である。

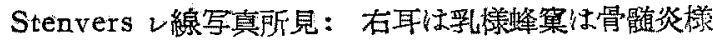

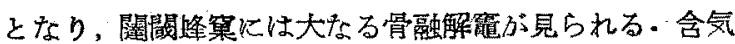
蜂窗像仕全〉認められない上半規管注認められるが，

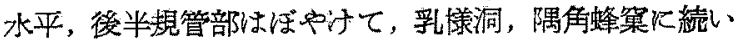
て和り辺縁が不明である・錐体帒は内耳道が僅か心現
図 4

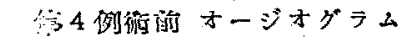

\section{AUDIOGRAM}

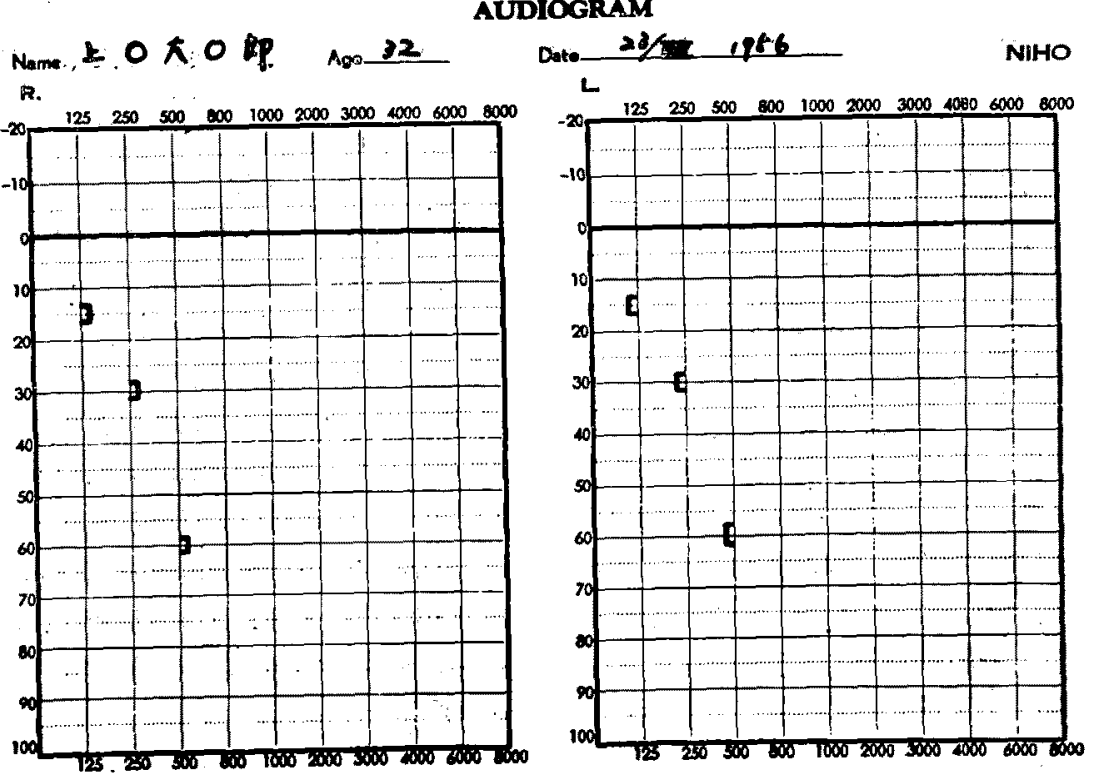


れている以外は一様に不鮮明となつていて硬い感じで

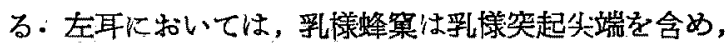
上陵まで全体が一様に不鮮明となつており，側頍镂部蜂 集も同㴍である. 右耳同様に上半規管は認められ\%が, 水平半規管，後半規管は暹緑が不明で，この除影は上半 規管の側方に続き，乳様洞より乳様蜂䆞内に移行してい る・錐体尖は右耳同㨾に不鮮明とならておりり，更に一層 不繁明の度が強い。

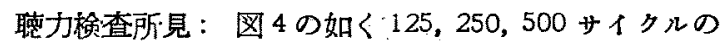
骨導のみである・耳の傍でどんなに大きな声を出してす 全然かからないし，傍を通る電車の音も少しも聞えな いたさ本人はアクセントのない奇妙な応答をするだけ である・漸く意味がわかる程度で主に単語を話す。

遮眼書字法梌查：図 5 に示す如く変化はないようで あるが，质耳共に内耳性変化か強いため一見通常のすの と変りがないのではなかららか.

昭和 31 年 8 月 30 日左側頭骨炎根治手術十水平半挸管 部分切除術を行い，9月25日右側頭骨炎根治手術+水 平半規管部分切除術を行つた。

図 5 衍前遮限書字法 （左 㵂眼時）

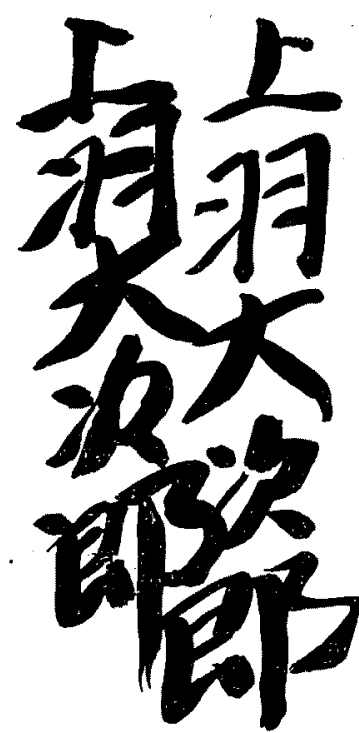

左耳手術所見：耳後切 開により外耳道上标後方よ りり整開を行つた所，骨は維 密となつており非常に硬く 通常の含気蜂集は少しす認 められなかった・僅かに隅

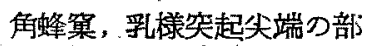
分において，死骨化した海 綿状の骨組織及び硣膿が認 められた。乳样洞は殆ど維 密な骨組䅧により充たされ ていて，その所在が不明の ため，Stacke 法沉より乳 洞入口部を決め，外耳道後 壁に先に整形を行つて指南 をつけた後少しつっ削つて 行つた・しかし洞らしさむ のは存在しなかつた・婛等 所見としては战膜は殆ど全欠損の状態であり，鼓宣内に は仮性真珠腫塊が充満しており，その中に槌骨は小頭つ み存在して拉り，砧骨は不明，鐙骨は消失していた・鼓 室壁は厚い肉芽組織で被われて括り，上皮化している部 分もあつた，外耳道前壁は正常の数倍にも愿く硬くなつ

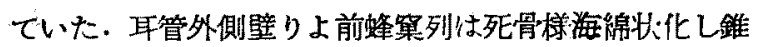

体尖烧続いていた，次いて乳様洞の部分の增殖骨を注意

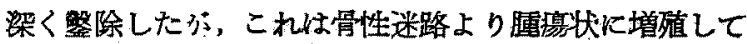

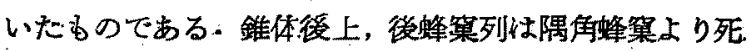

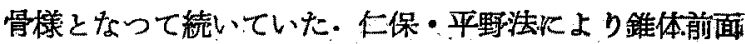
骨を除去し，更に錐体尖学除去したが，非常に硬く除去 に困難を感じた：斯くて側頭骨炎根治手術を終えたが， 聴力は全然なく，よつて水平半規管部開空術を行っ た. 水平半規管部か骨は極めて厚く，恰も遁堭の姐くに 隆起していて，2 2 3mm 削って激く膜様迷路を露出し た所，眩最登作を生じた。膜様迷路は黄色を呈してお り，Schambough 鈎Kより骨空縁を应大して，更に外 淋巴腔を開放，更に一部膜持半規管を掻爬除去して；前 後の半規管内腔よりの内外淋巴液の流出をよくした。次

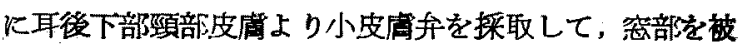
覆した・術直後には人の声, 笛の音 (ビー，ピー) が響 くよらになつた。

右耳手術所見：耳挠切開により入るに，左耳同㥞骨 は高度に䌟密となり，蜂巢らしきものは存在しないここ の繳密骨を整開して乳様洞火入つたぶ，通常の場合こ比 較して非常に狭くなつていた・谟かに閖閵㛔策の部分が

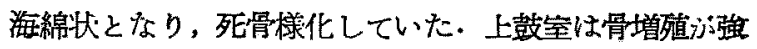
く，更に肉莱組織が埋めてお，り，㱠膿が潖められた・棺 骨，砧骨汢骨性に湢着して全然動かず，一緒に除去し た・しかし予期していた仮性真珠腫は見当らなかつた。 鼓室壁に括ける肉芽組織は厚くなつて括り，般痕化して いた. 外耳道前壁はやはり左耳同様に数倍に厚くなつて

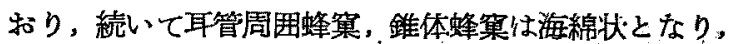
死骨化していた・仁保・平野法による錐体前面骨る同様 であった・錐体尖を除去後，仁保式鐙骨截除鎾子炕て鐙 骨小頭を切断除去した・㯖力はやはりないので, 水平半 規管の開空を行つた・やはり迷路骨壁は厚く、膜様迷路 は黄色を呈していた・この際の脑最は左耳手術の際のる のより更に強く，頻回の嘔吐を稆り返した・Schambough 鈎に上り膜椂半规管を一部除去し，前後の半規管胵 よりの内外淋巴液の流出をよくしだ・次に小皮膚弁によ る開密部の被覆等を左耳と同様に行つた。術直後には 20 年振りに笛の音初めてどーと聞えるようになり，人間 の声は意味はかからないが，音が聞えるようになつた。

病理組織学的所見：手術に採取した側頭骨各部よ りの組織片を軟部と共にッェロイジン包哣し， ヘ・重 梦色及びワ染色により検索した。

$$
\text { 左 } \text { 耳: }
$$

（1）外耳道上柬：骨の变性が極めて強く見られる. 
骨の核は概ね消失して括り，広義つ骨小管驸近に見られ るすのは濃㜚,偏在等の变化を呈している.骨小胵つ㹡大 しているすのも多く認められる・紋理は不明潦となり，

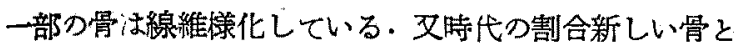
古い骨が入り混つている部分す見られる・文接合質の变 化により脆弱化し，骨が㤝らばらになつた所見す見られ る.これ等つ骨の周用よりの裔状吸収は少ない. 又骴新 生像は少しむ認められない。この骨において最も著明な のは骨小管の堌加々，その内外の変化である。骨小管の 骨内膜層に相当する部分は，ーマトキシリンに濃染して 肥厚している・この内部には浮朠，Fibrosis が見られ，

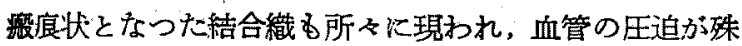
飞強くなっている. 又中には骨小管内腔が殆ど新しい時 代つ骨て埋められている部分すある。八管に扎いては， 敕部組織俚概小厚い海痕性結合織であり，血管を取り巻 いていて血管空内は空虚のものが多い，骨小管淿限ら

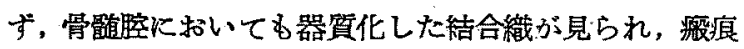
状の厚い細長い結合織つ存在しているるのもある。骨小

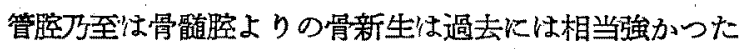
のであるが，現在は認められない：却つて管腔の周囲に 顷ける比較的年代か新しい骨（吻論变性が強い）に特い て，管壁よりの脱灰化が著明に見られる・軟部組織てお ける細胞漫潤は認められない:

(2) 乳樣突起尖端：骨の核は消失して括り，皎理つ 不魿明となつている所が多く，骨壁はへマトキシリン炕 染まつている・最る特改のある点は, 軟部組織仙総て骨 䯚組織で脂肪簿であり，骨梁には骨小管は極めて少な い.これは長期間の病変のために含気蜂窠は発育でき す，止むなく脂肪骮組織が腔を充たしている所見であ る・骨組織に打ける吸収，堷殖所見は全然なく，又細胞 浸洞等の炎症性变化す見られない。

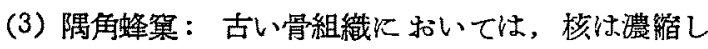
ており，赦理も不鮮明となっているが，鋸困状比裂し た接合線が骨質中に多数見られる・八管よりの骨の破壊 治湑機転はあまり見られないが，軟部組織，主として骨 揭腔，及び骨小管腔を中心とした骨の培殖が強く，数条

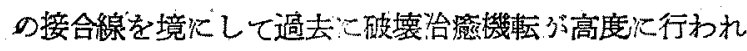
てきた事を示している。こか管䐦内からも再び埛状吸収 の起らている部分が惩められる。骨䯣胵，骨小管腔等つ

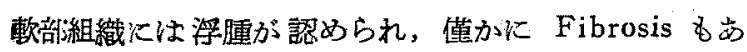
る・眰内注搪張した血管，淋巴管が多く見られ，血管

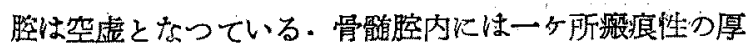
い結合織炕よる器質化が見られる・しかし炎症性細胞唚
潤，造骨細胞，破骨細胞等は見られない，

（4）隅角峰集天蓋：脆弱化してばらばらに離断され た骨組織は核の消失が者明であり，变性つためて骨層板 つ部分が染色されず，層板間ぶへマトキシリンを取り， 却つて通常とは別個つ絞理引゙鮮明となつている部分引゙多 い. 又骬小管表還さかるに従い骨の脱灰化も著明となつ て括り, 变性の種々雑多つ階程つ骨組織が混在してい る・不整形に拡大した骨小管腔には，浮腫，Fibrosis が見られるぶ，細胞浸潤は認められない，人管より増殖 した骨組織もその接合部より離断され，变性に宿つてい る・骨小管胵，骨賄腔，八管上りの骨の增殖厂j至は吸収

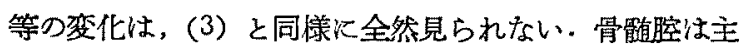

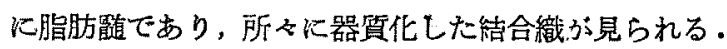

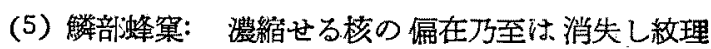
の不鮮明な骨組織は，離断が著明で，概ね八管を中心 としているようである・八管はその数を増加して和り，管 胵内は仪縮して括り，その血管胵内は赤血球に乏しい， この八管腔内が消失しているすのも見られる。骨婂し て結合織の厚い層が見られるが，細胞浸㵎林認められな いここれ接する骨組織こや〉多孔筫化が見られる。

（6）乳様洞：骨の変性の最も高度つ所見を呈し，脆 弱化に上る離断は一㬝著明となり，不整形化扰大した骨 小管，八管及ひ含気蜂案を中心として，又との上らな規 則性もなくばらばらになつている・こつ小骨片を見る そ，核刀濃縮；消失があり；紋理つ不鮮明な飞の，骨小 腔つ拆大，更厄は多孔質化，脱死化が進及線䊒様化した 部分もむる。これは不整形注拡大している骨小管腔より 修復機転が旺ん纪起つたつであるが，到底古い変怛の強 い骨組織岏修復され得ず，更に頻回の急性堌悪见より新 生骨む次第こ变性火宿つていつたbのである。管内腔 には浮腫があり，六管よりの骨の修復作用山殆ど認めら れない，不整形飞抎大した骨小管腔内には浮朠が強く見 られ，Fibrosis \&多く，血管俚狭少とならている。こ の部には通常ならば含気蜂㮤が多いのであるが，標本に は僅か汇1つ認められる・その大なる含気蜂案仙上皮譄 には变化があまり認められないが，上皮下棂には浮腫が 強く，一部肉芽組織が増殖している所見である. 細胞 浸潤は認められす造骨，破骨細胞も又ない。

（7）骨性迷路より增殖せる骨：（6）と同様に骨の離 断所見は著しく、ばらばらになつている・骨の变情も極 めて高度である.多孔質化, 線維㥆化, 又接合質の変化 により隐弱化し，ばらばらになり，本来の縹密な骨性内 耳の骨とは似て車似つかすのとなつている。軟部組織 
に括いては脂肪政直が見られ，その辺緣は浮䝵つ強い結合 織により骨と接している・1 所重圆扁平上皮が管代を なして，比較的古い結合織の中に見られる部があるぶ， これは仮性真珠腫つ進展と考えられる. 文不整形心拉大 した骨小管腔も多くなって括り，腔内には浮腫が強い。

（8）上鼓室の外側：やはり骨の離断は著しく，骨の 核の消失，浱縮，䋆理つ不鮮明は時代の古いるの程著し いこの骨の離断縁にはへマトキシリンに漕染する接合

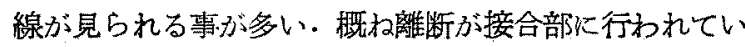
る事を示している・含気蜂窂被覆組織に接し，文取り囲 まれている小骨片群は，更炕死骨化が著明でへマトキシ リンに濃染しており，多孔望化の所もおる・この含気蜂 巢被覆組織の上成は1〜数層飞増殖し，肥厚して敊り， 上皮直下には細胞浸潤が軽度に見られる・上皮下層は浮 腫ろ゙強く，10数倍に肥厚し，更に症璂性の 結合織に移

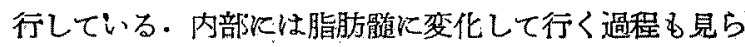
れる・これは第 2 例つ左耳隅角䗋巢の所見賚似してい る・骨小管内に和いてる脂肪䯣と見られる変化がある。 含気胵内には资症性出物が見られる・八管，骨小管つ 変化は (7) と同㥞である.

（9）後，後上㛔集列：骨は大部分つ核が消失をきた して敌り，敉理も不鮮明となつている.更に骨が脆弱化 しばらばらになつた所見が晃られる。咀小管はをの数が や〉増加し，不整形の拢大が見られる．骨小管内腔には 浮腫が強く，肉芽組織の侵入している部分るむる・八管 腔内軟部組織け収縮しているものと，浮属をきたしてい るものとがあり，その血管腔は空虚となつているものか゚

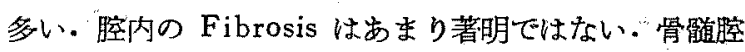

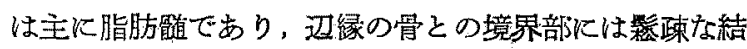
合織が存在している，八管腔，骨小管腔，骨䯣腔からの 骨の修復機転はいづれも認められない。

（10）鼓室天蓋：脆弱化した骨組織仗やはり骨の離断 が著明である・八管，骨小管を中心にして骨はばらばら

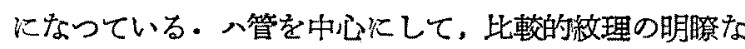
あのもあり，又骨の脱灰が強く多孔質をきたしているる の，骨がや小楾稚様となつているるの等があるが，(8) に比べると变化の割合がや」少ない上うである・，管 腔，骨小管腔は概小狭少となつて蛙り，管腔内の浮腪が 強く，Fibrosis も多い，軟部組織の大部分は脂肪䯚で 西り，赤色檤が僅かながら見られる。これ等軟部組織心 は急性炎症性変化が見ら礼ず，造骨，破骨細胞歹又見ら れない。

（11）外耳道前壁：骨組織刀核は大部分が消失してお
り，骨小膯る拡丈している・更に2〜3の骨小腔の融合 している部分る見られ，多孔質化が著明である・紋理は 不鮮明となり，全体として脱灰が強く起つている・模が 消失してい西所では，へマトキシリンに染色された骨細 胞膜が収綰して骨小胵から遊離している所見が多い，広 義の骨小管腔内㳄部組織は収縮して括り，骨内膜層は一 マトキシリンに浀染している・このや\收縮した軟部組 織内には Fibrosis を認炀る。管腔内血管腔には赤血球 は乏しく，骨に対する修復機输は殆ぞ行われていない。 勿論造骨細胞，破骨細胞も見られない。

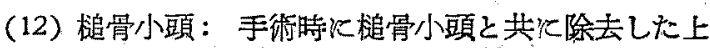
鼓室内肉芽組織である。肉茅組織㤬厚く，一方において は症痕状となつて扣り，内部には数個の管状をなして仗 性真珠腫が侵入しているのが認められる：この重層扁平 上皮は数層となつていて，その上皮下には高度細胞漫 潤が見られる・細胞浸潤は主に円形細胞，組織球，好酸

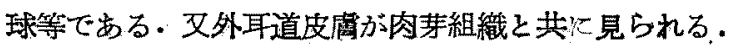
骨病変は極めて高度で，周囲上り管状火破罣せられた腔 が見られ，内膜はーマトキシリンに濃染肥厚し，内腔绀 浮䭪，血管の㹡張，一部はすでに脂肪娟に変化した所見 す見られる・血管腔内は盗血を示している・即ち以前と は相当の骨破壤腔だつたるのが，急性炎症状の消退と共 に斯かる組織で一応平衡状態を保つている所見である。 骨は殆どの核は消失し，比較的へマトキシリンを多くと り，紋理の不鮮明，新しい時代の骨と古い時代の骨との 閒の接合線が見られ，殆ど死骨化している所見である。 斯かる所見では耳小骨連鑜としての役目は到底果せす， 却つて個体にとつては異物的存在となつている。

（13）錐体尖（仁保・平野法）：霄はや性り同様炕ば らばらになっている、骨の变化は（10）とほら゙同㴍であ る. 不整形に抎大した骨小管腔には Fibrosis があり， 又脂肪骾となつている所すある。

（14）解剖学的錐体尖：骨の变化は更に強くなり，ば らばらになった骨の核は消失しているるのが多く，嵈縮， しているるのもあり，骨筫は骨層板飞相当寸る部分が染 色せられず，木の年輪つ如き異常敘理が著明となり，骨 啳板の中間部は却つていマトキシリンを余計ととつてい る.この脱死化が更に高度になると骨層板は離れて，ば らばらの玉憼の上らになつてしまう．更以進むと骨の1 つの尿は線維つようになつてしまつた所見も見られる。 骨小管:腟は浮腫が高度で，血笛の任迫が強く見られる。 八管，骨小管つ周辺の骨には脱灰の起つている部分が多 い. 軟部組織では脂肪䯣も多くなつている。骨組織の变 
性传高度となつているのに修復機枟は少しる認められな w.

\section{右 耳:}

(1) 外耳道上棘：骨の核は大部分濃縮し，粒理さ不

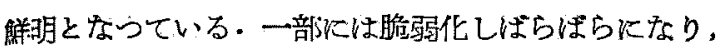
めるいは骨小腔の㹡大，融合により多孔質化された部分 らある：骨は骨小管の堌加及び管腔の㹡大が著明となつ ている・切り方によってす異なるが，こつに情円形， 円形つものが多く見られる・骨内膜層はーマトキシリン に㡙染して扣り，骨小管腔内には厚い結合織が血管を取 り巻き，一部には洀痕状となつたるのが充満しているも

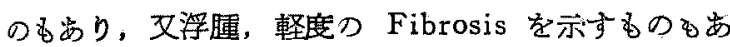
る.造骨，破骨細胞，細胞浸潤等は見られない。この骨 小管の 周囲には，小骨片に脱灰の起つているものがあ

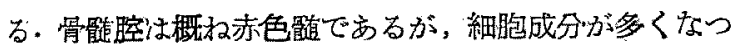
ており，肉莱組織が堌殖している。

（2）乳様洞の外側壁：この部は通常は含気峰窠が多 数认存在する部であるが，この標本では含気蜂杲に相当 する部分圢，総て骨小管内腔を充たす浮腫儿軽度の線䊒

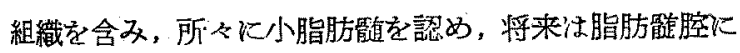
発展しようとする組織で置換されている.骨内膜は肥厚 じへマトキンリンに灌染している・骨の変性は極めて 強く, 核は濃綃乃至は消失し, 全体として比較的へマト キシリンに浱染している・骨の脆弱化によるばらばらの 所見，骨小腔の拡大，融合汇よる多孔質化，文八管を中 心として玉苟の如くに輪をなしてばらばらになつている 所見等が見られる・八管，骨小管腔内はいら゙れる浮腫が 高度であり，Fibrosis が㦘められる. 又管腔内血管腔 はいつれる狭少となつている・骨小管腔より吸收像が見 られる所もあるがこれは少なく，增殖像は見当らない， 細胞浸潤等の炎症性变化すない。

（3）乳様突起尖端：脆弱化した管組織であり，骨の 離断はぬ灶り高度である・しかし乳様洞に比べるとや〉 軽い。この骨組織もや注り变性の強い所と弱い所と先 り，“周辺に和ける遊離骨片程脱洃が強くたつている・文 染色性飞悪く、へマトキシリンを薄くとつている・筋肉

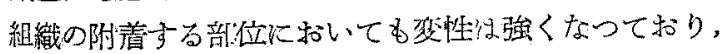
脱灰が見られる。他つ部位に执いても核は殆ど消失して

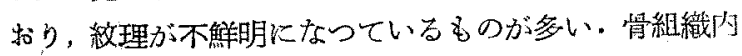
に注入管友び骨髅腔が主に見られ，骨小管は少ない、 管活変性の強い骨組織のもの程，管腔内軟部組織の収緭

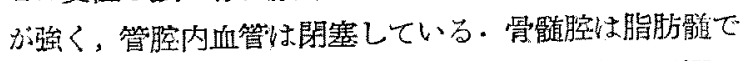

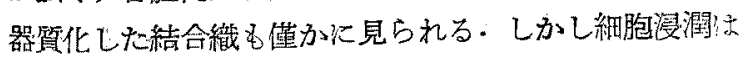

殆ど認められない。

（4）隅角蜂案：骨組織は核の消失文は湢縮，紋理つ” 不鮮明となつている所が多く，骨組織内にはや〉へマト

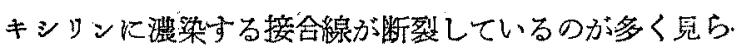

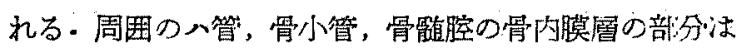

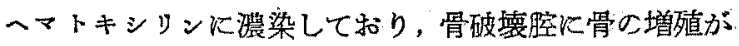
行われている部分もある・斯かる新生骨は比較的に土ォ ジンを余計取り，骨質はや小緻密になつている。しか し軟部組織火は造骨細胞恃存在しない，骨小管は幾分堌 加して括り，この腔内軟部組織には浮腫が強く，Fibrosis が僅が認められる。更飞骨小管内腔がすでに脂

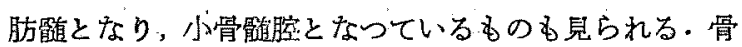
小管よりの受の吸収は明らかでない，別な部分にかなり 大きな肉芽組織が認められる・外骨膜尿，結合織の高度 に肥厚した所完である。

(5) 乳様洞：骨の新生,变性が高度厄繰り返された所 見で，骨の紋理が隇茶隇茶になり，又骨の脆弱化が強く 骨の離断所完が著明となつている・核の消失したものは 少なく，多くは骨小腔は拡大し核が濃縮しているが，紋 理は不鮮明となり更に脱灰化が見られるるのが多い，殊 汇軟部組織化团まれている小骨片はその傾向が強い，軟 部組織では骨小管腔が増加し八筸も增加している。この 腔内に括ける浮腫, Fibrosis は乳様洞の外側壁とほよ゙ 同椂である・1 個の大なる破壊腔内の軽度の細胞浸潤， 浮腫，軽度の Fibrosis を示す軟部滔織の中に一見含気 腔と見られる数個の小腔があるが，これ等はその内容よ り見ると骨髄腔に発展途上のものであり，斯かる軟部組 織からは骨髄腔が発生して来る事が明らかとなつた。

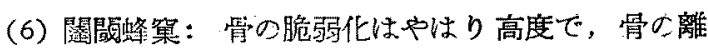
断が強く，小骨片に分離している・このばらばらになっ た骨变性が高度で，染色性が覀くなり，へマトキシリ シに薄く染まつている・核の罯縮乃至沵消失も著しくな つている・学小管周辺に見られる比較的時代さ新しい骨

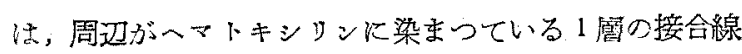
により，周囲の士い骨組織と分れているが，これも強度 の所では脱灰化している。骨小管腔机いつれる高度の浮

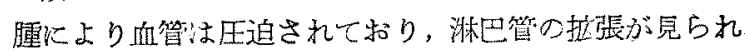

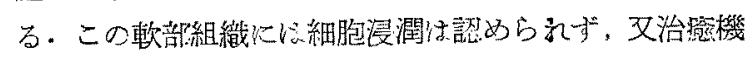
転も全然昌られない。

（7）上鼓管の新生骨：骨，骨小管膑，骨䪔腔及び比 輘的硬くなった結合織つ入り混つた所見でする。骨の離 断所㫕が強く，小骨片に分れ，婴の核は大部纷が消生 し，緅理壮不鮮明となり高度のものは死骨化している。 
骨質の線維様となつているもの，脱灰の著明なるの等変 性は強く，殊に周辺の軟部組織内のものが高度つようで ある・骨組識内には八管が多く見られる・八管内には浮 腫が強く，Fibrosis も僅かながら認められる・骨䯣腔

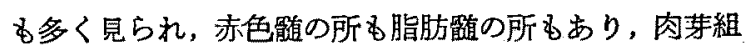
織の形成されている所も㐫る・又骨の周团には手術時の 出血が認められる。

（8）䄸骨：手術時见砧骨や上鼓案内増殖骨組織と共 飞，骨性て癒着していたるのである・桘骨小頭は桘骨柄 に比へ，Osteoporose の状態が著しい.变性の強い骨 組識には，骨小管が周囲の骨破壊により著しく拡大され て括り，腙内には浮腫，Fibrosis が強く，又細胞浸潤 が認められる・血管は縮小しているるの，拡張している るの等種々であるが，㹡張しているるのは概ね腔内に血 球の充満しているのが見られるここの骨小管腔より骨の 新生の見られる部分すあるが僅かである・棺骨柄に特い てるやはり同様の所見であり，桘骨小頭に比べるとや〉 八管が多い上うである。八管腔内の血管胵は閉塞してい るもの>如くである・枹骨柄の骨小管腔には細胞浸潤は 認められない，耳小骨連鎖としての役目は恐らく果さ す，却つて異物的存在となつて伝音には邪蜜になつてい たように思われる。

（9）砧骨：ばらばらになつた骨組織は変性の程度の 種々の小骨片の集りであり，全く強度のOsteoporose の状態を呈している.骨小管，骨䯣朌周辺のるのは，核 の濃縮，紋理つ不鮮明となつているすのが大部分である が，その他のものは染妾りが悪く，骨の脱灰や線維様化 をきたし变性が高度でむる。八管内腔红結合織の増殖が 強く，血管の閉塞は高度である。骨小管，骨瞋腔は多く は管腔の拡大が見られる・大型のもの>血管は拉張し， 血管胵内には大抵赤血球ぶ充満しており，その周囲には

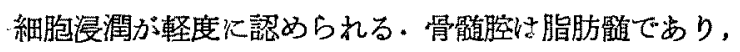
器質化している部分も見られる。

（10）骨性耳管：骨組織は時代の新しいもの，古いも のすべて変性が高度で死骨化している・核は殆ど消失 し，叔理は不鮮明となり骨質は染まりぶ悪くなつてい る.紋理つや小はつきりしているものもあるが，これは 溜板が脱灰のために染をりが悪くなつて，恰る紋理つ如 く見えるのである・骨は八管，骨小管を中心として離断 が強く、ばらばらになつている、この八管，骨小管内の 浮嗹はいつれも高度であり，Fibrosis も認められる。 一部の八管，骨小管内には厚い結合織が形成されている

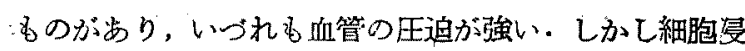

潤は認められない. 又この部分では骨䯣腔は認められな W.

（11）解剖学的錐体尖：骨の核の濃縮，效理の不解明 等が見られるが，骨性耳管の部より変性の程度が軽い。 骨の 周囲の軟部組織つ大きなものは殆とが骨䯣腔であ

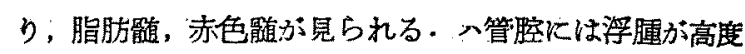
であり，骨小管腔には Fibrosis，浮堙が認められる. これ等の軟部組織上りの沿瘉機転は殆ど認められない。

術後経過：左耳手術後，術前には存在しなかつた耳 鳴が「ジー」と㭙々聞えた。この耳鳴は7\%重曹水 60cc トビタミン $B_{1} 100 \mathrm{mg}$ 静注後は「ゴー」と変化し, 間 むなく消失した。この耳鳴は断続しながら約 10 日間続

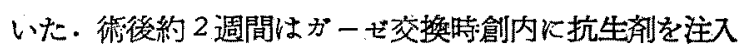
する際に色々耳の中で音がし，又他つ音は響くようであ ると答えていた，少し動かすと眩量があり，展々嘔昛し たが，経過と共に欣第に回数は減少していた. 術後 2 週 以後、創内の出液が多いので，術後 18 日目に忙抗生 郕つ創内使用を中止した。術後20日目に色々の音学聞 かはをが、やはり響くけれどむ音にはならないとの事で あつた・左耳術後 25 日目に右耳を手術した. 第 1 例同 様に続いて絶刘安静を保たせたが，それでる震タ銦量， 嘔昍があり，その程度は左耳の䀧より強かつた。しかし 聴力は左耳に比べるとかなり良く，創内にはガーゼが充 坥されているのに，術後6日目頃まで，意味はわからな いが人間の大声は聞えていだ・これ以後は創内の液 のため, 塄力は低下してしまつた. 右耳手術後 17日目 維带交換時に遮眼の上，右耳の横で手を吤いた所；自分

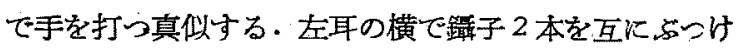
る音を聞かせた所がカチカチと答えた。この頃から再び 聴力が徐くに出てきたようである. 左耳手術後47 日目 (右耳術後22 日目) にラジオを，音量せ一番大きくして 耳の傍で聞かせた。所が両耳共保聞光，左耳より右耳の 方が少し良いようだ答えだ。意味はわからないが，音 の高低はわかるという・ラジオが聞えるので非常に嬉し いと云つていた，手を当てると更烺くわかるが，これ は振動が入るので当然と思われる。この時から病室の裹 $15 \mathrm{~m}$ 位の所の電事の音が聞えるようになり，見えない のに進行方向を指さすようになつた。

左耳術後 68 日間 (右耳術後 43 日間) 恃絶刘安静を取 り，7\%重曹水+ビタミン $B_{1} 100 \mathrm{mg}$ 静注は 78 回行つ

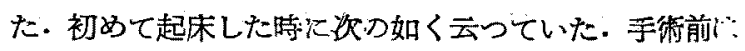
音が何む入らなかつたのに，今では色々の音が入る. 即 ちラジォではドシドン (太战の音)，ブーブー(ラッハ 
图 6 管 3 例少後 4 力月目ホージオグラム

\section{AUDiurumam}

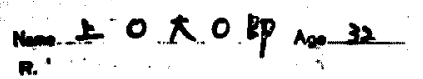

R. $125 \quad 250 \quad 500 \quad 000 \quad 1000 \quad 2000 \quad 3000 \quad 1000 \quad 6000 \quad 0000$

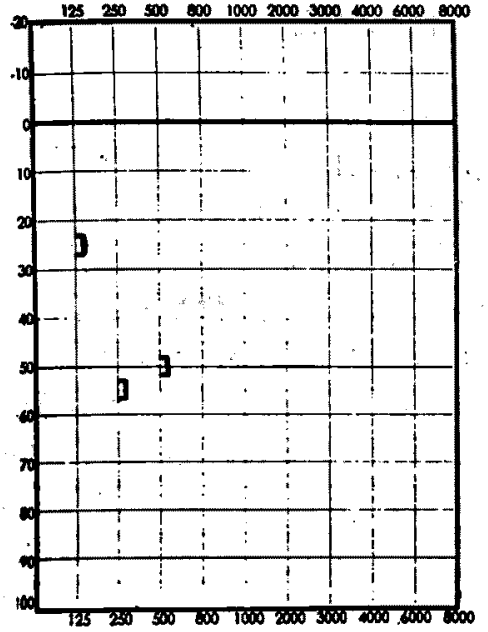

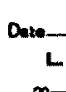

L.

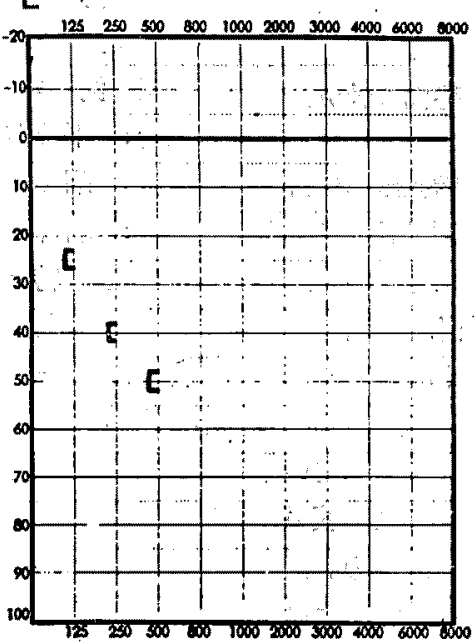

図 7 管了例衍後㵂哏書字法 (左. 㵂眼時)

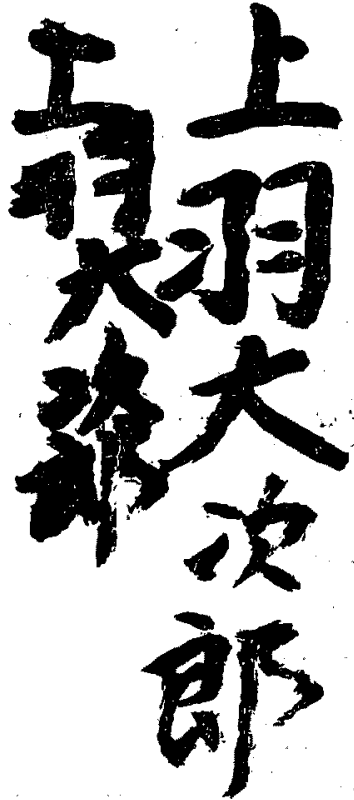

の音),その他にはゴウゴウ(電車の音),ビイービイー (笛の音) と聞える．文手術前は頭が鉛の如く重がった が，今は非常に軽いと云つている。この時に左耳より約

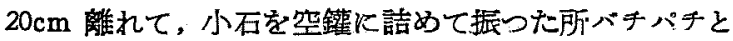

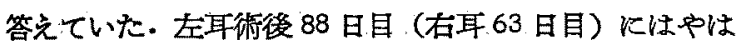
り右耳の方からの聞えがよいと云つていた，術後60日 目頃火は両耳共沅完に上皮化完了した．左耳術後 97 日目より骨導補聴器を付けたが，これで聞くと少し大き な音なら大体艺れらしい意味の事を答える・それで骨尊 䋠聴器をつけて，単語の発音を練習させる事に努めた。 術後 4 カ月目のオージオグラムは図 6 㕛遮眼書字法江図 7 の如くである.

術後半年目の遠隔成績では，シジオ虫単純な音なら普 通の音でかる. 又発音汢よくなつていると・家人の話 では耳洗をした後などは非常に聴力がよいようである。 しかし普通の会話はまだ無理だとの事であつた。

第 3 例総括：奻巟期に 所謂中耳炎に罹患し，それを 慢性化させたために小学校 1 年の頃より高度難聴とな ク，言語の特殊教育を受けなからたたために，我々には到 底聴取できないような言語となつてしまつた。左㑡は仮 性真珠腄を生したが，右側は仮性真珠腫性ではなかつ た・レ線では典型的の慢性側頭骨炎の像を呈していた。 オージォグラムでは骨導は全く引人掛からず，僅か火低 音部の骨尊のみであつた・人の声は耳の傍でどんな大き な声を出してる声も聴取できない：

この両耳に対して両側な頭骨焱根治手術及び水平半規

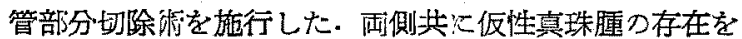
想像していたが，左側沈認めたが，右側代住喼めなか つた.

耳小骨連鎖俚両側共儿高度儿骨性こ痛着していた。両 側共に乳様洞，上鼓室の管増殖恃甚だしく，殊に左側で は何処が乳様洞か判らない位であつた. 水平半規管より の骨増殖が最も甚だしがた・鼓室の肉芽は肉芽と云う

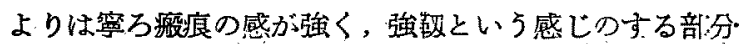
が多かった－前蜂菓列蚮らかい䍜患骨が続き，又脆弱 の感が強かつた.

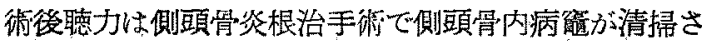
れたざけで注改善されず，両耳共黄色を呈した水平半 規管の 部分切除術を施行して；内外淋巴液が 漏出する と，耐耳共 20 年振りに笛のピーと人の声の音だけが少

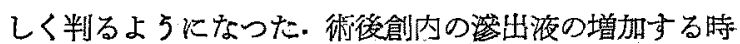
期は聴力は落らるが，上皮化と共に上昇し，術後オージ オク゚ラムは図6である。術後半年目の問合せ対して は、ラジオは単純な音なら普通の大ささで判る。言語つ 発音沈大分良くなつたが，普通の会話は未だ無理との，事 であつた.

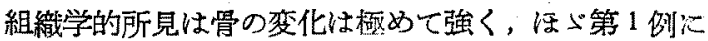
匹敵する，骨の核は概ね消失又は涪縮，偏在し，骨小胵 の拡大融合しているものるある・骨の紋理は不焦明とな り，あるいは骨層板つ部肪染まりが悪くなり，その中間 
部ふぶートキションをとり，却つて㟟常な層板つ紋理が 見られる所むむる.更に接合質の変化炕より脆弱化し骨 がばらばらてなつた所見も見られる・又骨の新生渡壊が 長年月繰り返されたために，含気蜂偞が発育すべき部分 に，㭙代つ新しい骨，古い骨，いろいろの時代つ骨が存 在し，極めて複雑な構造を呈している。

次に本例で注主に脂肪䯣ではあるが，骨䯣組織が非常 に多い. 即亏乳幼児期に相当程青以上の側頭骨骨䯚炎に なつた場合には，通常の含気蜂集の発育はできない，而 るこのような骨病変の高度つ場合には，全体が緻泌骨で 修復される事はなく，骨喵道腔，あるいはそれて類似の広 義つ骨小管を埋めている如き組織で病的骨組織の間㗂は 埋められて，軟部組鐵と骨部との均衡を保とうとしてい る・しかしこの程度つ骨病変性到底自力によつて破壊吸 収して，これる新生骨で置換する事よ不可能であり，又 骨病変は軟部組織の治痖学好げ，広義の骨小管内腔には 浮婳，Fibrosis を誋め，血管を圧迫し体液循環を障碍 し，益々治瘾を要延せしめている。

斯かる变化は隅㑇蜂窠天蓋, 鼓室天蓋, 錐体尖前面骨 においても同㴍で，従来の骨内板を出せば手術を終りと すう事惊りであり，骨の变化が悪ければ硬脳膜を露出 して骨内板子除去する側頭骨炎根洽手就が 合理的な事 が，組織学的にも証明された訳である。

恥骨連鎖の骨病変子極めて高度で，周囲より管状に 破壊せられた腔が見られ，内腔は浮腄，血管の㹡張，一 部炕はすでた脂肪髄に变化した所る見られる・聚小骨は 元来硬固の骨組織で，八管，骨㵦胵がこのように認めら れる事はない，左側は桘骨小頭のみで周囲肉芽組識に仮 性壹珠腫が浸入し, 右則怯桘骨, 砧骨共に Osteoporose を呈している・斯かる耳小骨は治痖の妨げ，又伝音の妨 げはしているが，伝音の役目は全くしていない，Myringoplasty, Tympanoplasty, Myringostapediopexie の際は注意を要する所見で号る。

左側水平半規管より増殖した骨，その膜様迷路壁を検 索した所見を述べよう，元来骨性内耳の骨は極めて緻辖 硬固の上等の骨である・この骨が 孔だらけになつてい る・その腔浮腫を主とした軟部組醅で理められ，一部 は管䯣腔となり；更に仮性真珠腫の侵入も諗められる。 これは骨破壊腟に血管，肉来が侵入し，斯かる所見を呈 したもので，通常の営羑を司る八管が骨破壊によつて抬 大したものとは趣をを異にしている・内部の膜様半規管 は黄色を呈し，明らかに斯かる骨小管腔を年しての慢性 内耳炎の発生も㐫り得る事が証明された。斯かる㚆化は
蝸牛に和いて子想像せられ，“斯かる骨病変，慢性半規管 㷋が除去され入ば蝸牛が減荷せられ，ある程度々の機能 が回復し得る場合の存在する事汢想像に難くない.この 事は第 2 例火扣いてる同漾に考㝋られる。

症 例 4

患者：平○高○，1年7 力月. 8

初晾：昭和 30 年 10 月 8 日

主訴：右耳漏（敬留）

家后歴：特記すべき事岋ない。

既往歴，現病歴：生後 4〜5 カ月目位より被の開閉に 気付いたり，一寸した物音に振り向いたりしていた。半 年目位から，わけのわからない事を云つていたぶ，物音 に注感で動作见現れていた．生後 1 年 2 カ月目以麻

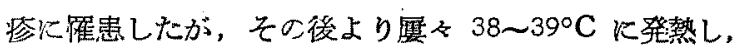

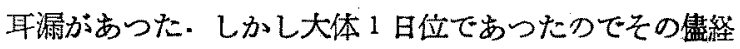
過した・この頃より難德が現れたようだが，麻掺の時 に受けたストマイ注射のためだろう・爻この鼓膜なら聞 えない訳がないと云われていて両親も大して気火止めな

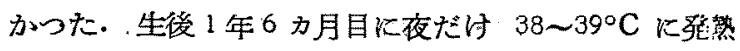
し，5日間続いた・約 20 日間感冒と云わ机て治瘭を続 けている中心，右耳漏に気付き来院した。

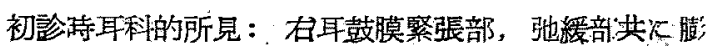
隆肥厚し，幾分発赤があり，後上部には穿孔があるよう 飞思われる・左耳の鼓膜は発赤腫脹が強い. 又両側屚朓 肥大双びアデノイド堌殖应が見られた。

経過：右急性穿孔性測頭骨含気䗋窠炎两び左急性測 頭骨含気蜂窠炎の診断の下に，左耳鼓膜穿刺仁より粘㳖

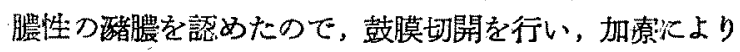
急性炎症状は消退したが，两鼓膜の肥厚混濁は消失せず 半沢を欠いていた，通院中には扁桃炎による 発熱によ り，2〜3度急性増悪店状 (耳漏)を繰り返した。その後 程過を観察していたが，聴力は殆どないようで，発語は 奇努な声を出すだけである. 以前の如く物音に振り向く 事もない，試又聴力検查を行つてみた所，1000サイ” ル，2000サイクルでは気導で最高音を出すと笑つて眼を

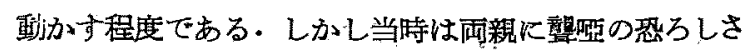

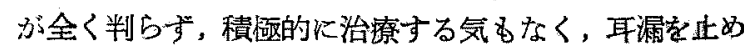
ればそれで良く，その中に聞えて来るだるう・又るッ イなら止艺を得ない位ていた。その後扁桃炎による発熱

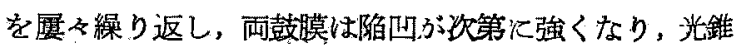
は依然として認められなかつた。翌年て昭和 31 年 9 月

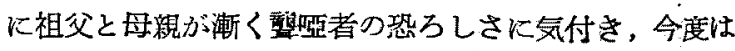
積柾的に何とかして呉れと依頼してきた。そこで偩頭骨 
の状態を知るためレ線撮影を行つた。

Sienvers $レ$ 線写真所見：左耳は乳羕洞，後半規管 周围より発育せる蜂窠は，むる程度まで発達している

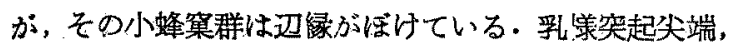

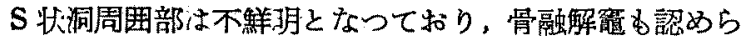

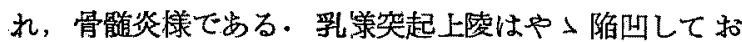

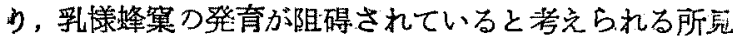
で岁る・上半規管，後半規管は陰影がぱつきり認められ る.錐体尖はやっ不鮮明となっているが，蝸牛款つ陰影 性概ね認められる・右耳は乳様洞，後半規管周囲上り発 育せる蜂巢は左耳より大きく，䚬部蜂集にも及んでい る・而もこれ等小蜂笨群は辺绿の割合はつきりしている わの，不鮮朋なるのが混在しておら，左耳同様に一部に

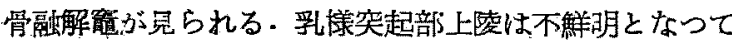

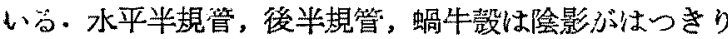
して拈り，錐体尖はや」不鮮朋で岕る。

レ線写真上り側頭骨炎つ存在が明らかとなつたが，先 す誘因を除くべく，耐側扁桃摘出術及びアデ，トミ一を 行つた・翌日の鼓膜所見は右耳は緊張部陷凹があり， 後上部は混濁している・左耳は緊張部がや〉陌凹してい るがや入色調が良くなってきている。しかしそれ以上に

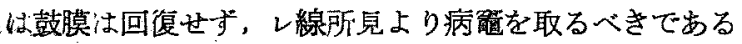
々考え，両耳手清を行つた。

昭和 31 年 9 月 25 日左保存的側頭骨炎根治手街，10月 6 日右保存的側頭骨资根治手術を行つた。

左耳手術所完：型の如く耳後四開より入るに，乳荃 突起部表在性烽巢は，その配列が乱れて括り，骨はや」 脆く海綿状となつている.含気蜂窠被垍組織はや小浮腫 状に肥厚して所沉より粘夜性膿を含んでいる．乳様笑起 尖端は炎症に侵されて海綿様になったものか，又は蜂巢 が未だ発䏍しないで骨髄組織を含及海綿様を呈している

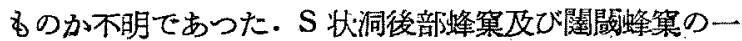
部死骨樣となつていた・錐体乳様洞周囲部の变化は強 く，殊江上半規管附近上门錐体後蜂集列，後上蜂察列 は最も死骨化が強い。これ等を及心限り蛋爬した：上 半規管の中の 弧形下道にはな和病変を諗めたが，森田一 Frenckner 法行行わなかつた。止鼓室を清掃して，鼓 膜，耳小骨は可及的に保存した。

右耳手獄所見：表在性蜂巢は骨組織が柔らかく，海 綿状となつて招り，蜂菒つ配列が乱れている。乳様洞附 近の蜂临は肉腿的所完は比輍的良了，被覆組織つ浮腫を 認めるのみであるが，骨の脆弱化は相当にあり，鋭匙で ぼろぼろ播爬された，乳様突起尖端さ海綿状となり，死

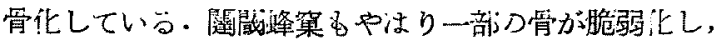

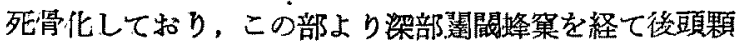
に到るまで，海綿状の骨が続いて括り，死骨化が見られ る. 又この部を搔爬していた所，後下蜂㮤列が意外火大 きく，内耳道つ下まで死骨化した骨が続いていた・頼骨

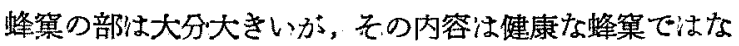
く，海綿状つ骨の中に小蜂笨が点在し，骨は脆くなつて いた.この部を搔爬し，左耳同㖨に上鼓室を清掃し，保 存的に術を了した.

病理組織学的所見：手術時儿側頭骨各部より採取し た組織片を軟部と共にッェロオジン包埋しへ・王重染 色、ワ染色てより検索した。

左 耳:

（1）外耳道上棘：骨汢比較的变化の少ないものと, 新生破買が繰り返さ机変化の強いるのがある・しかし概 权骨は核つ大部分が消失して拉り，紋理の不明なるのが 多い. 殊に小骨片に执いては骨組䅧の染亲りが悪くなつ て扣り，更霄貲が線維洋になっているものが混在して いる. 叉骨小腔が融合したり，拉大したりして多孔質化 の所見を呈している部分すむる・更に一部の骨は脆弱化

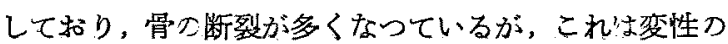
強い、骨㹸られる・八管，骨小管にはいら゙れも浮腫及び Fibrosis が認められる. 含気蜂笨はかなり見られ，上

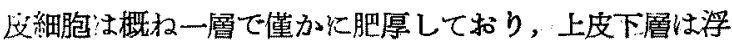
腫性に 10 数倍汁厚し，骨膜層が僅が肥厚している

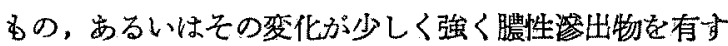
るるの，あるい快肉芽組織漾の变化を認めるもの等種 の階梯のるのが見られる・造骨細胞つ認められる部分も 尚る。

（2）乳様洞の外側壁：骨は比較的紋理つ明らかなる のから，不鮮明となっているるの，高度つ所で恃線維様 と劣つているるの迄種々湿在している・核は大部分が濃 樎して扣り，変性つ強い骨では概小消失し，又骨小腔が 拡大しているものが多い：この変性つ強い骨組織梳变性 の弱い部分火比べ。やつへマトキシリンを余訊に取つて いるが，全体としての染色性低下している，八管，骨 小管腔内には浮腫が強く，Fibrosis が見られる，含気 蜂㮤上皮組織住僅かて肥厚しているるの，相当に肥厚增 殖しているもの等種々の階梯つものが克られる・上皮下 層には概小強い浮腫が認められる・こつ部沉は細胞浸潤 の認められる所がある.合気腔内には膿性㳂出物があ る. 又上皮層が数倍湆殖肥厚し，上皮下は肉芽組識様 になっている所もあり，骨内膜層に造骨細胞の並列が見 
られる部分もある・

(3) 釈様突起尖端: 手術の際には蜂穼は発育してい， ないで骨髄組織を含む海綿様㕠患骨と思われたが，組織 学的検索では含気蜂笨組織が認められた・即ち含気蜂集 被㠅上皮は肥厚増殖しており，又上皮細胞は立方壮とな り，上度下畒には浮腫が強く，細胞浸潤を認め，上皮層 の肥厚増殖の強い部分では肉芽組織様になつている・又 一部においては結合織の増殖が多くなつている・含気腔 内には炎症性㳂出物が認められた。骨組織俚核の消失が 目立ち，且つ骨小胵の拡大が多くなつており，效理は不 鲜明となっているるのが多い. 一部の骨は比較的よく， 紋理の不鮮明，核の淟紑，消失，骨小腔の拡大等を示す のみで，エォジンに焱染しているが，一部の骨は破壊が 甚だしく，大小の孔だらけとなり，Osteoporose を呈

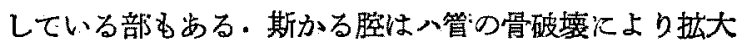

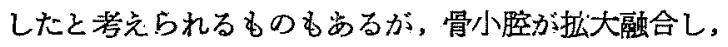

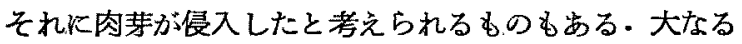
むのは骨破塤腔を形成し，内腔には浮腫，Fibrosis を 諮める・血管腔内は費血を示し, 細胞浸潤等の急性炎症 状はすでに極めて軽度となつている。

第 1 例, 第了例の極めて初期の症状と考えられる. 即 ち含気蜂笨炎怪度の部もあるが，かなり高度の部も市 り，骨炎も同様の所見で岁る・しかし未た新生骨にそし く, 従って Umbau に乏しい.

(4) S 状洞後部蜂集: この標本は骨と骨䯣組織より 成り，含気蜂巢はこの部には未だ発育していない，骨鲔

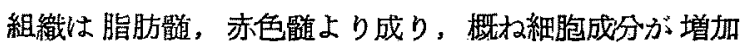
し，一部には器質化が見られる。骨は一様隹效理不鮮明 そなり，核の消失せる部分が多い，一部の骨小堙の拡 大，八管の拡大，周囲上りの䆚状吸収，その反対側には 造骨細胞の並列を見，Osteoporose の初期の所自を呈 している部分るある. 即ち狭義の骨能炎の所見を呈して いる・即ち斯かる所見と鼓膜所見を対比する時は，化学 抗生物質の害の甚大なのに一警する次第でむる。

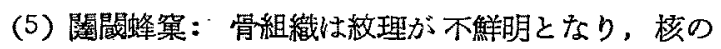
清縮乃至は消失をきたして和り，その間に不規則に断裂 した接合線が多いここの骨組織に，更に新生骨が附加し ている所見が芫られ，更に軟部組織より窩状吸収がこの

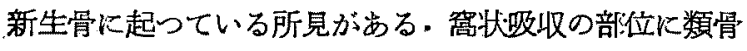
組織の現われている所もある・これ接する含気蜂集被 覆上皮は数層に増殖しており，上匢下には浮腫が強く見 られ，縕胞漫潤もや〉多くなっている.上皮下層には肉 莱組織の増殖の見られる部分も站る。含気腔内には出血
が強いが、これは手術游のすのである・この標本に拈い ては広義の骨小管が 1っ所認められるだけで，この部に おいては骨の新生により膑は縓小して和り，腔内には浮 睡が見られる。骨組織内よりの破䧇吸収は少なく，周囲 骨壁よりの吸収破壊が著明で，一部には骨新生，類骨組 織を認め，含気腔被覆組織の变化も強く，彷来称えら加 た急性乳様突起炎の組織学的所見でする。而して元来側 頭骨の骨組織には八管はそれ程多くはない。

第 1 例，第2 例，第 3 例俔られ䓃広義の骨小管は病 的骨比刘抗して，出るいはこれを修復せんがためにでき た腟で，本来骨の営養を司る八管とは少しく趣きを異に している.含気蜂案隔壁に両側の被覆組織骨膜層より営 盖されるから旔康であれば八管はそう沢山むる必要はな い. 即ち長年月の間の Umbau の結果できた所見であ る.

(6) 後, 後上蜂窠列 (山下法): 骨組織は染まりが悪 くなつて扣り, へマトキシリンを薄く取つていて, 全体 として死骨化の傾向があり，文肉芽組織の中に死霄化し た小骨片を認め, 又器質化した骨咀組織に接して死骨化 した小骨片を諮める部分もある・核は大部分が消失し, 骨小腔は㹡大し，紋理は全く不鮮明となっている・骨組 織の周囲には筒壮吸収が㨋明に認められ，造骨細胞す少 しは兒られるが，破壊機轱のちが著明である・骨小管胵 は以前の骨堌殖のために縮小しており，腔内には浮蕾が 強い. 含気蜂集は上皮が肥厚し，数圈に増殖している： 上皮下には浮痦, 細胞浸潤が多くなり，一部には肉芽組 織が認められる。

\section{右 耳:}

（1）外耳道上棘：核は大部分の消失をきたし，叔理 が不鮮明の所及び錯綜の著しい部分と，核が濃維してい るが，紋理の割合に認められる緻搳化している部分とが 混在している，後者の骨壁には造骨細胞の並列が多く， 骨の堌殖所見が認められる・骨小管は不整形に㹡大して 特り，骨破罗胵急性炎症状が消退し，次第火修復され て行く所見で，腔内には浮腫が著明で Fibrosis が強 い. 又器質化も見られる・八管はいつれも浮腪のために 血管の王迫が強い，骨の昅収所見は著明てはないようで ある・周囲の小骨片に括いては变性はや〉強くなつて抹

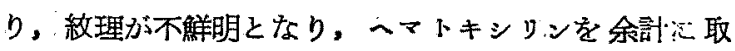
り，更に骨組織の断裂が認められる・左耳に和いては含 気蜂窠が認められたが，右耳に括いては全く見られな い.これは炎症により破壊せられたすのであろら。

（2）乳様突起尖端：造肯細胞が更に多く見られる: 
即ら骨壁には1〜数層の造骨細胞つ並列があり，八管， 骨小管内にも多く認められる・この部分と执いて新生骨 す見られるがここの所見は造骨細胞て比して訬ないよ ちである。造骨細胞に取り囲まれている骨は核の濃縮が 見られる方，紋理つ鮮明なるの，不鮮明となつているる の，骨の染まりが悪くなつているもの等種なである。こ れ以外の部位に和いては骨の変性惊度となつている。

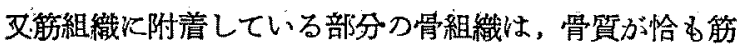
線維の如き相呈している.含気䗋寞被覆上皮は数倍 に增殖し，上皮下には細胞浸潤が強く，結合㵶が堌殖し ている・造骨絊胞つ存在する部分の軟部組織には，浮腫， 結合織の増殖が見られ，更にこれが骨贿道，主に脂肪髄に 移行している・要するK高度の骨变性を伴つた含気蜂巢 炎，骨艏炎の所見であるが，左耳手術後 11 日間抗生剂 療法を行って後の所完ですり，斯かる高度つ骨病变を伴 つた側頭骨に対しては，扁桃剔出，アデトミ一，化学 抗生物質療法がいか火無力かを示す所見で，聴力保持の ためには早期の保存的側頭骨炎根治手術がいか儿大切か を如実に物語つている。

(3) 鱗部蜂窠: 古い骨組織はへマトキシリンを薄く そり，骨の紋理は不鮮明となり，核の消失が目立ってい る.文骨小胵も㹡大している.この骨組穖には骨小管腔及 び周囲の骨壁より骨の新生が行わ机ている・即ち軟部組 織には 1〜数殿の造骨細胞の並列が見られる所があり， その部分に骨の新生が認められる・又破骨細胞も別な部

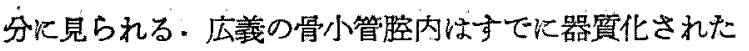
わのが多く，又浮腫が認められるるのもらる・辺縁には 細胞浸潤が軽度儿存する. 又肉芽組織様になつている部 分もある.含気蜂集は小なるすの 2 個と大なるるの1個 が芫られるが，その被覆上皮はや、肥厚し，上皮下組織 には浮腫が強い部分，むるいは一部上皮下組織がすでに 器質化された部分, 内腔に法出物を認める部分がある。

(4) 後頭顆澾する病筃: 骨組織は，変性の種たの 階梯の小骨片に分れている・骨の核は消失し，紋理は不 鮮明となつているるのが多いが，肉芽組織内の小骨片は

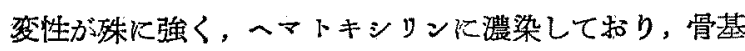
質は不規則な濃淡の模样を画がき，周辺の肉芽組織より の窝状吸収により鋸蒾状の骨壁を形成している・しかし 又別の骨片においては骨壁に造骨細胞方見られ，骨の新 生されている部分もあるが少ない。带の周辺軟部組織灶 主以赤色䯣であるが細胞成分が堌加し，一部分に因芽組

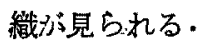

（5）頓骨蜂窼：骨の変化は極めて高度で，核の䀼縮
乃至は消失，骨小腔の应大，多孔質化，紋理つ不鮮明な 骨組織炕破壊が起り又管の新生が何回にひ起った事を示 している・骨組織内には不規則て断裂した接合線が䜅め られ，骨壁には類骨組織つ形成が見られる・又時代の新 しい骨との境にす類骨組織が現われている。八管及び骨 小管よりも骨の新生が認められ，管腔は縮小している。

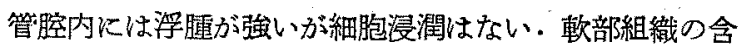
気蜂显は，上皮は数層に肥厚増殖している.上皮下には 浮腫が極めて著明である.この上皮下層が肉芽組織樣儿 なっている部汾があるが，細胞浸潤恃軽度である。

術後経過：左耳手術淔後鼓膜は陥凹がとれ，肥厚る

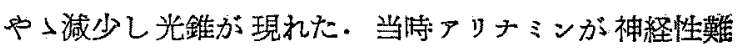
聴に用いられ始めたつで, 術後 2 日目より毎日 $5 \mathrm{mg} つ$ つ 180 mg 使用した. 最初繃带をしていたせいか，術後 の聴力は判然としなかつたが，術後6日目にトラックが 通つた時に振り向いて，その方向を見るようになつた。 左耳手術後11 日目に右耳手術を行つた。左耳同様に鼓 膜の陥凹十消失し, 光錐引出現した. 右耳手獄後 5 日目 からは，電車が通ると何む兒えないのに指さして，出つ ちへ行つた，こつちへ行ったと方向を示すようになり， 14日目にはラジオを聞きたいと䭾々をこね，耳を傍洔 つて行き聞く事ぶ㷴タとなつた。右耳手術後 17 日目に 約 $1 \mathrm{~m}$ 離れて普通の声で扰早ようと声を掛けるとすぐ 振り向き，再び同様な事を間を置いて行うと，同様に振 り返る・左耳は術後30 日目に繃帯を除去した所, 腕時 計を耳に当ていいる.而る回診時にはブザーが鳴るが， これが鳴ると，腕時計と両方を指さして同じだといら． 試みに夜小さくノックしたが，振り向かずにドアの方を 指で教古る・左耳手衙後 35 日目に初めて口の中でぶつ ぶつ云い出した。術後 47 日目紙芝居の柏子木の音がす

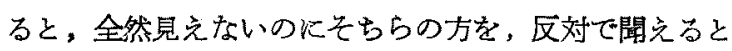
その方向を向く、㕛眼党し時評を耳の傍からだんだん遠 ざけると，耳をその方に持つて行き，後万に持って行く 々振り向く. 左耳術後50日目より1日中意味のわから ない事を云つていた(ブー，バー)，その後も大体同㴍に 経過し，約 2 年後には戸を閉める音で振り向いたり，後 ろ向きから大声を出すと振り返ったりする状態である が，意味のわかるような言葉は話さない，鼓膜は術前の 状態より逥かに改善され，僅か火混罢を見るが光錐もあ り，非常によい所見であるが，聴力検査ができないの で，数字で表わす事はできない，言語の世界には未だ戻 らないが，しかし残聴は相当にあるように思われるの で，更に今後つ経過を観察し，側頭骨炎根浩手亜，内耳 


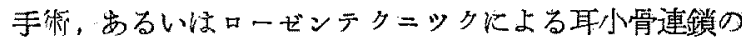
修復老行ら考えである。

第 4 例総括： 2 年 6 力月の幼児. 1 年 2 力月の時儿麻 沴に䍜患し，その際に所謂両側急性中耳炎飞罹患したら

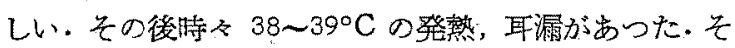
の頃より難聴が現れたらしいが；麻疮時に受けたスト マイ注射のためだろろ、文この鼓膜ならば聞えない訳は ないと云われて山まり気にも止めなかつた。1年6カ月 の時再び 38〜39 C の弛張熱が現われ，20日間感冒と して治療を受けたがよくならず，耳漏に気付いて来院し た・その際な既火音炕反応しなくなつていたが，正確な

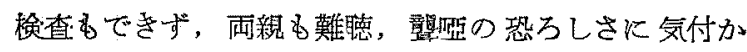
ず，その机話すようになるだろ5位でいた。

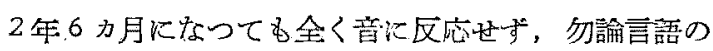
修得も皆無のために今回は手術をしてでも何とかならぬ ものかと来院した。

鼓膜生所謂中耳炎残貽症劣るい山慢性中耳加答胃で希 り，レ線では両側慢性側頭骨炎であった。

本例に刘して先ず両側口蓋扁桃摘出並びにアデノトミ 一を施行し，先ず耳管よりの再感染を防禦し，次保存 的側頭骨炎根治手術により乳様洞上り入口部，上䞚室を 経て鼓室に流下寸る膿汁を止めた。

斯くて鼓室, 前䗋菒列, 前下蜂集列及び錐体尖に対 $\mathrm{L}$ て化学抗生物質療法を行つた.

組織学的所睍を要的すれば高度の慢性含気蜂穼炎，骨 炎，骨䯣炎である・含気蜂巢被覆上皮は背が高くなり； 堌殖し，上皮下の組織層には浮侢，細胞浸潤を認め，あ るいは既に器筫化されている部分もある・㷊血，充血を 認める洔期は遥か心通り過ざている・骨膜層も肥厚して

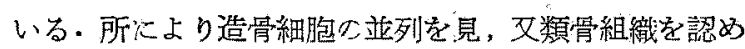
る部分むおる・文夜性，死骨化した骨組織を運び去るた めの破骨細胞に上る窩状吸卭む見られる。

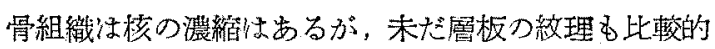
判り，染色性が変化してへマトキシうンのとりすが僅か 火多い比較的変化の少ないるのから，核は消失し殆ど染 色されない高度の死骨化した骨組織，岕るいは变性し紋

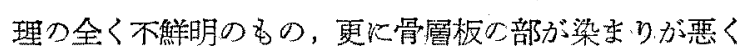

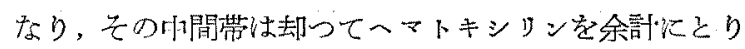

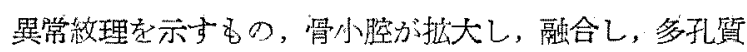

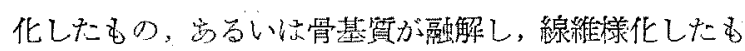

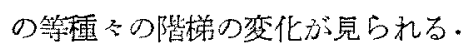

しかし第 1 例, 第 3 例に見られた破壊，新生を繰り返 し，時代の新しい骨と古い時代胃が錯綜して存在し，
正常な側頭骨とは全く別個の構造となり，即ち吉田て䜊 5. Umbau の高度の所晃を呈し，更接合筫吕变化し て骨は脆くなりばらぱらになつた所見は極めて少な い. 文骨破壊腔，骨小管腔の Fibrosis 6第 1，第3 例 より遥か火少なく，これ等の腔内の脂肪䯣の出現も遥か 飞少ない。

即ち斯かる古所見が幸いに骵膜炎，敗血症等により生命 を落さずに3〜5年と経過すれば第 1 例，第3例の如く， 骨の変化と軟部の変化との均衡がとれて，却つて骨病变 を修復するだけの気力がなくなり，即ち細胞浸潤，造 骨細胞の出現，破学細胞の出現等はなくなり，浮腪， Fibrosis，貧血が現れ，骨も修復されず，病的の骨は又

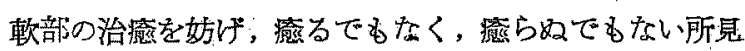
を呈するものと考える。

淀 例 5

患者：宮○加○○、2年6 力月. ㅇ

初猃：昭和 31 年 5 月 1 日

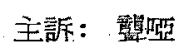

族家歴：特仙記す事なない。

既往症，現病歷：出生時住仮死状態であったとの事 である.生後 2 力月目上り先天性股関節脱日で加蹽浡行 つていた：生後半年目位には片言を話し，時計の音や雑 音にもよく目を覚したという・ギブスをかけた頃（生後 6 カ月の終り頃) 百暖に䍜患し, $40^{\circ} \mathrm{C}$ に発熱した。 耳の熱ではないかと云われて耳科倸受診したという。 その後, 生後 8 カ月目頃より音がしても全然反応しなく なり，頭も後るに反るよ5になり，小睍麻痻の諸䄽查を 受けたりしたが，その方は異常がないとの事であつた。 生後 1 年目にビタミン $\mathrm{B}_{1}$ の注射 40 本行つたが変化 なく、耺々として診察を受けたが，異常がないとか，2， 3 年後でなければわからないとか，あるいはストマイに よるものだろろと云われたが，諦めきれず来院した。

初猃:耳利的所見：右耳の鼓膜緊張部は浸潤巴厚少 著明であり，や〉陥凹している．後上部て肥厚してお。 り，発赤が強い，左耳は後上部上り外耳道にかけて骨性

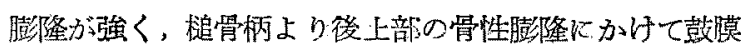
の肥厚膨隆が著明である・鼓膜の前下部は漫潤肥厚して

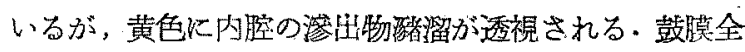
体としては陌凹している. 左鼓膜穿刺にて抵抗があり，

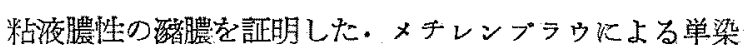
色表行つたが，白血球と，剔離した上皮細胞を認めるの みでせつた・右鼓膜第刺では鼓膜の抵抗が更に強く。血

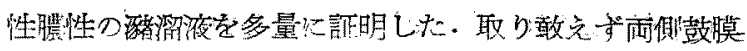


、甽開を行つた・皏内所見ては両下甲介の腫脹が強く，発 赤あり水様性鼻汁が多い，常に口をあいており，又流滬 わ非常飞多かつた・アデノイド堌殖所㓂が岕り，咽頭扁 桃るかなり肥大している。

Stenvers ᄂ線写真所見：右耳恬乳様洞周辺に骨融解

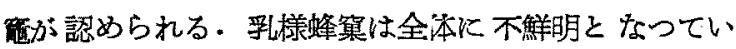

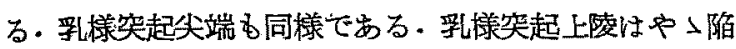
凹して扣り，従って弓状隆起は高くなっている・上半规 管，後半規管は不鮮明ではめるが認められる・左耳る大 体同様であるが，乳様突起上陵の陌凹は右耳に比べると 少なく，弓状隆起も高くない。

レ線写真所見より慢性側頭骨炎が証明され，峷膜所 見，教膜穿刺所見よりこれが回復は手術以外には望めな いので初診後6日目に入院した。

昭和 31 年 5 月 7 日雨側扁桃摘出術 及び アデノトミー を行い，更に右保存的側頭骨资根治手術を行った・同年 5 月 21 日に左保存的側頭骨炎根治手術を行つた。

右耳手術所見：耳後切開により入つた所，外耳道上 棘より後方乳様部の骨表面には骨小管の㹡大が見られ， 且つ䙮色倅色していた. 外耳道上棘直下て乳様洞の外

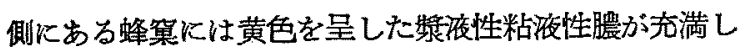

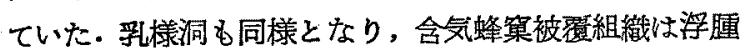
性に菙脹一部分は黒褐色となつていた。S状洞は強く前 方炕突出し，乳様突起部天蓋硬脳膜も低くなっており， 典型的な危険性側頭骨で，上線写真で推定した通りであ

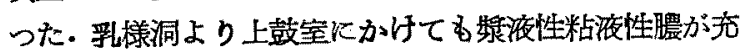
满しており，隅售蜂俥にかけて骨は海綿状死骨化が強 く，蜂窂の隔壁は注ろぼろである・乳様乫起尖端は蜂集 の発育が悪く，殆と蜂集らしきるのは見られず，海綿状 となり死骨化していた，煩骨蜂窂を掻爬し，迷路周囲部 を特に慎重に掻爬した. 弧形下道は黒褐色儿变色してお り，森田・Frenckner 法により提爬を行った。上鼓空 で耳小骨の周辺には肉莪組織の形成がかり，粘液性膿が 充満していた・これ等を除去して術を了した。

左耳手術所見：外耳道上棘より後方乳樣部には骨小 管の拉大が著明であり，更に後方の骨壁は菲薄となり， 青く透けている所見であつた.骨の鳌開を行うに，表在 性䗋窠の骨組織は死骨化して軟らかく，一部は褐色とな つていた・透けて青色を呈した部分である・且つ蜂穼内 には粘稠膿が允满しており，乳様洞にも同峨の所見が続 いていた．隅角蜂案つ発育ば良好であるが，死骨様とな

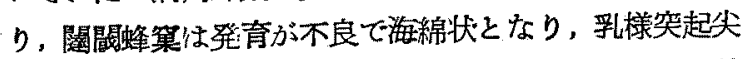
端す同様に蜂窠の発育が悪く，更に死骨化が著しい，外

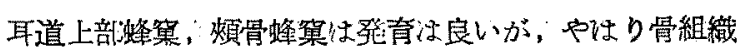

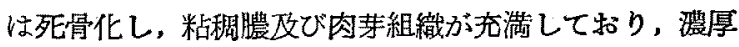

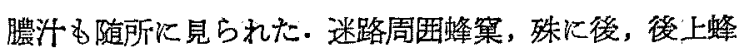

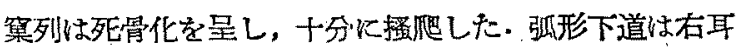
同粶に黒色变色していた・上鼓室は粘稠膿及び肉莱組 織更に死骨化の強い骨組織で埋まつて括り，これ等をで きる限り除去，砧骨をを露出して術を了した。

病理組織学的所見：手術時化採取した側頍骨各部を 骨軟部共にッェロイジン包理，へ・項染色及びワ染色 により検索した。

\section{右 耳:}

（1）外耳道上柬：かなり大きな含気蜂巢か゚1ケ所認 められる。この上皮は数層飞增殖して打り，上皮直下に は高度の細胞浸潤䉕が 3 ケ所市り，更に多形核白血球， 円形細胞，形質細胞，好酸球，組䋨球等が出現してい る.而も上皮下層の浮䭪，Fibrosis 汃強い.上皮下層

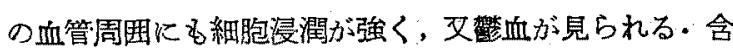
気腔内には脷脱した上皮細胞，白血球を含を出物を認 める・骨組織㤥核の澧縮，消失し，紋理は全く不鮮明と なつている部分が多い，一部には骨小腔が㹡大してい る.この等つ骨組織は骨と 軟部組織が交錯し，軽屡の Osteoporose 呈している. 軟部組織は炎症により細

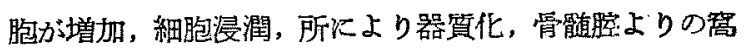

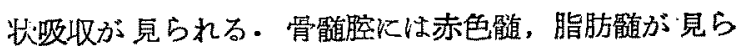
れ, 又明らか红骨破罱腔が修復される途上のるの, 又八 管が骨破壊火上り㹡大され，その中に細胞浸潤，Fibrosis, 周团の造骨細胞の並列を見るすの等種々の所見で ある・明らか炏含気蜂巢炎，骨炎，骨䯣炎の湜在した所 見である。これが手術時に外耳道上棘附近に認められた 褐色の小孔の組織学的所見である。

(2) 乳様突起尖端：骨組織と軟部は骨䯚組織より成 り，含気蜂巢は認められない，骨は核の消失が多くな り，紋理の不鮮明な古い骨組織が大部分である・骨小管

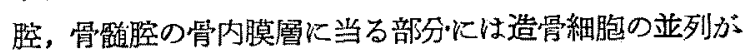
むり，周图に骨新生が認められる・骨小管腔内柱に肉 莱組織であり，骨新生つ一方に括いては吸収所見る見ら れる・小骨片殊闪茅組織内にあるるのは变性が更に强

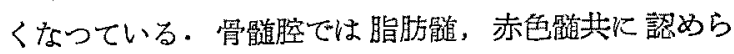
れ，浮嗹，細胞増加，更に肉莱組織，骨壁には简状吸 收，造骨細胞の並列も認められ，骨髄炎の所見である。 骨組織の筋組織火移行する部分・では骨組織が帢も筋組織 の如き所見を呈している。

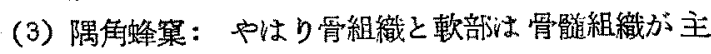


である、骨は核の消失が多く，骨小胵の拉大しているむ のも多い，敉理法不鮮明となり小骨片のるのは染まりる 覀くなつている・八管教るい炡骨小管においては一庭吸 収が起り，後に堌殖により管腔が縮小された所見を呈す ๖・新旧の骨の境の接合線はンマトキシリンに濃染して

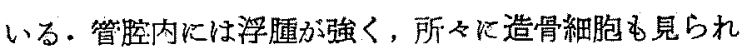

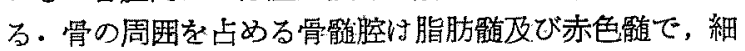
胞仙や増加して特り，辺縁に造骨細胞が㒖かに認め られる・且つ骨の新生所見い僅かであり骨壁よりの吸収 像も著明ではないこの骨髄腔は通常ならば含気腔とな るべき部分であるが，恐らく頻回の急性増悪により含気 蜂倮之して発育できず，斯かる骨髄腔になつたるのと思 われる，骨に接して肉芽組織が見られ，骨䯣腔内には器 質化を認める部分もある。

（4）S 状洞壁：骨の核の消失しているすのが多く， 骨小胵の掋大しているものがあり，骨が多孔質状となつ ているものか゚辺緑に近く見られる. 又紋理け大部分が不 鮮明となり，一部に錯綜が著しい，骨小管，管簿脘周辺 には骨の新生が兒られ，中には管腔㤃骨に埋められて消 失している所見も2〜3山る。骨小管腔，骨破壊腔は器 質化されたるのが多い，即ち炎症は八管を通り頭蓋腷内

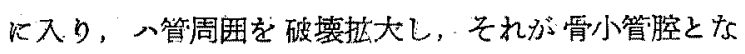
り，骨破壊腔乏なり，あるいは骨䯣腔を破壊して同様の 所自を呈し，炎症山硬脳膜で喰い止められ，その後次第 に修復が進み，このような所見を呈しているものであ

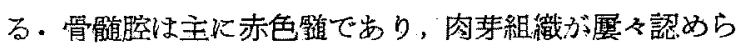
れる・又骨壁に近く器質化強い。

（5）鱗部蜂㝠：骨の核の消失, 紋理の不鮮明は更に 著明で骨質は染まりが悪くなつている部分が多い，骨質 《は数条の鋸粎状の接合線て走行を認める.骨の吸収に 上り挝大した骨小管の内腔には肉莱組織代堌殖してお

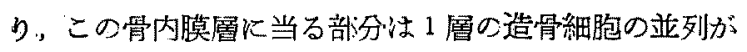
めり，これ接して類骨組織も僅かれ認められる・而も これが更に肉苏組織により吸収されつつある所見も見ら

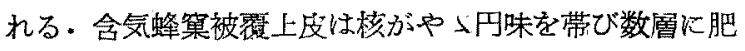
厚増殖している.上皮下圈には浮腫が尔り細胞浸潤が強 くなっている。含気胵内には手術㭙に打ける出血が見ら

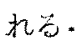

(6) 乳溙洞: 軟部組織に囲まれた骨の変性は高度で

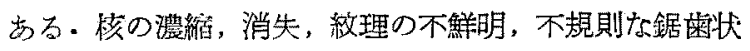
の接合線つ見られる骨組織は染をりぶ德くなって扣り， 周围より僅かながら吸収が行われている・文骨片が全く 死骨化してしまらたるのもある・や」拨大した広義の骨
小管:より骨の堌殖が行われた形跡が出るが，骨組織が全

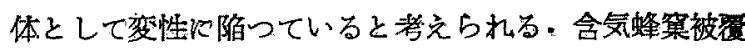
上皮は数倍に肥厚增殖し，上没下下注細胞浸潤が高度と なつており，浮董が認められる. 又肉芽組織となつてい、

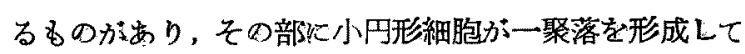
いる所見飞見ら机る。

（7）小脳部骨内板：比の部分は通常は緻密な骨で劣 るが，この骨では孔だらけである・骨破㯖见より拉大し た八管，骨小管，骨䯚腔等が多数見られる：これ等の管 腔に近い部分では骨の核は濃縮しており，その他の部分 では消失しているものが多い，粒理は不鮮明となってい る所が多く，一部儿破㯖新生つ繰り返しを物語る異常效

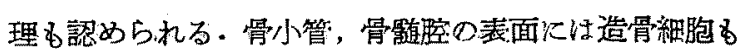
見られるが，学の新生は著明ではない，骨小管腔には浮 腫，Fibrosis が見られる・骨䯣腔にとは細胞成分の堌加， 細胞浸潤, 器質化等の炎症性变化を認める. 文肉莪組幟 の部分では变性した骨に吸収が行われている。

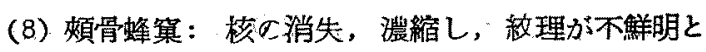
なり、へマトキシリンに淡染する恋性の強い骨組織は, 周囲軟部組織仗上り頻回に破壊を受け，更に堌殖を繰り

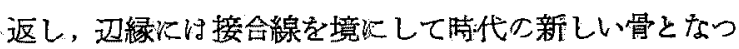
て括りこのような接合楾が数条見られる・而も骨は全 体と乙て死骨化し，軟部組織より吸収が行われている。 軟部は含気蜂笨組織で，上皮は背が高くなり，核は円く なり，数圈に増殖している，上皮直下には細胞浸潤が強 く，上皮下層は極端に厚く全く肉芽組織と化している。

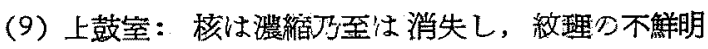
な古い変性の強い骨組織が中心をなし，これて接合湶を 境化して次第に時代の新しい骨が周りを取り囲んでいる

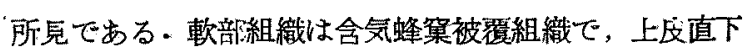
の炎症症状は最る強くなつて和り，高度の浮腫が上皮下 層に㒻られる・即ち慢注孚様突起炎急性增悪刀所見であ 吉.

左、耳:

（1）外耳道上棘：著しく㹡大した広義の骨小管腔， 含気蜂菓組織により吸収を蒙つている骨組織は，紋理は 不鮮明となつている所が多く，一部の骨において核核も 消失して怙り，骨小腔の拡大が認められる。殊に小骨片 飞和いては更に変性が強くなつて拈り，死骨化してい る.骨壁に近つくに従い鋸蒾状つ接合線が多数現われて 和り，過去の骨の硬鉬增殖相当強かつたものと思われ る・文骨壁に纪造骨細胞の並列孔見られる：骨の吸収所 完は殆ど見られない，八管注極めて少ないが，いづれる 
周囲の骨増殖により縮小されているものが多い，骨小管 险には浮連が強く，辺縁には肉茅組織が見られる。軟部:

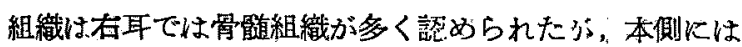
全く認められない，その殆どは浮腫を主とする上成下の

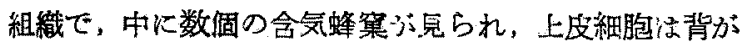
高くなり，堌殖し，周囲に細胞浸潤を認めるるのお

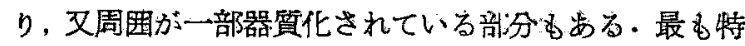
異点は一部の上度下にキレステロンの結晶を中心にし た肉芽組織ができている点でるる。異物型巨細胞がこの 結晶の周りに多数見られ，組織球，形鿓細胞，多形陔白 血球が認められる。

（2）乳様洞の外側壁：骨の变性法著明で，へマトキ シフンにや小蕽く染まり，核は賑縮し，紋理心不鮮明と なり，骨壁に併行している接合線ぶ，辺縁江近く多数見

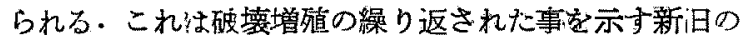
骨の境界楾で分る、八管け䒕られない、この骨組織を取 り囲む含気蜂笨組織は；上成方数層に增殖し，上皮層直 下には細胞浸潤が完られ，上皮下層は㱠ど器質化され， 又肉芽組織となり，骨の吸収が軽度に行われている。

（3）乳樣突起尖端：骨組織は核が消失し，紋理は不 鮮朋となり，へマトキシシンに淡染して扣り，全体とし て死骨化している。この骨組織には周囲の肉芽組織によ る吸収が僅かながら兒られる・最も特異な点は軟部組織 の裂化で，含気蜂窠つ上度が1〜数愿の立力上皮とな ク，上皮下には（1）と同様にコレステリンの結晶を中心 とした肉茅組織が兒られる・や汢り異物型巨細胞がこの 結晶の周りに多数兒られ，組織球，形質細胞，多形核白 血球が諮められる。

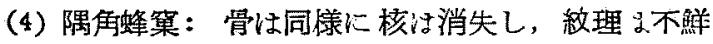
明となり，鋸籴状になつた断裂した接合線が骨質内に多 数見られる・骨はへマトキシリンに淡染して括り，全体 として茢骨㨾になつている・骨の破壊吸取の認められる

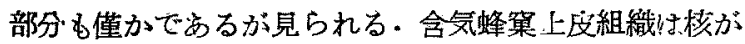
や小円味を帯びており，肥厚している・軟部組織つ器筫

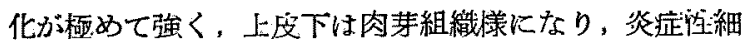
胞浸潤も多くなつている。

（5） S 状洞壁：この標本では含気蜂窠ゔ非常に少な ‥その西るのは上皮細胞が立方状となり，上皮下の 浮腫を主徵候とし，骨膜層には造骨細胞》並列を完，劣

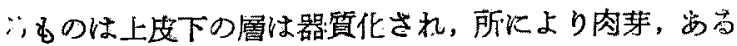
いは破骨細胞仗よる著明な霄吸収方認められる・骨の核

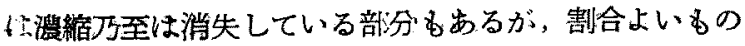
む劣る・骨の紋理は不鮮明な所が多くなり文不規則烧錯
綜している部分もある・周囲に見られる小骨片は変性が 更に強くなり，死骨化している・㹡大した骨小管腔を含 む軟部組織つ骨内膜層化当万部分况へマトキシシンKや や染まり，造骨細胞刀並列しているものが多い，骨壁に おいては，骨の增殖の行われている部分，吸収の行和れ ている部分が湦在している形でらる・而も裂は全体とし て变性は強くなつている，骨小管腔内に性血管の㹡張が 兒られるが，概ね臆内悾虚で西り，父周囲には浮腫 認められ，細胞浸潤む僅か火芫られる。

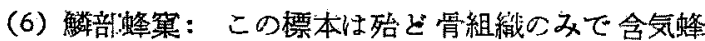
粱つ所見け全くない，骨の核の消失が多くなり，紋理は 不鮮明となつて全体として变性が強くなつている・僅か に認められる紋理は通常とは全く逆な染まり方になつて

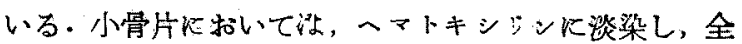
く死骨伦してしまっているもの屯施㟔。この部分で注骨 の断裂著しくなっている。この小骨片の周囲には籍蹯 な結合織が兒られるグ，吸収文は增殖等の機忶は見られ

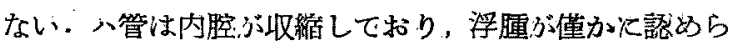

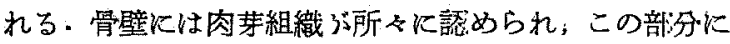
骨の吸収所胃が完られる。

（7）乳栚洞天蓋：骨組織の核は概ね消失し，骨小腔 の掋大している所完が多い，紋理は不鮮明となり，骨は ヘマトキシリンに淡染して死骨化している部分が多い。 八管；骨小管腔には時代か新しい骨が管腔を半ば理めて いるが，この骨も变性が高度となつている・骨小管腔内 は浮腫が強くなつている、軟部組織壮箖眯な結合織が大 部分で，脂肪䯣も僅が認められる・この部血管の㹡 張している所も京る・軟部組織の細胞浸潤は軽度となつ て和り，骨の吸収が僅か飞認められる・斯かる骨組織が 硬脳膜儿接して存在する时法，硬脳膜は肥厚して病気の 頭蓋内進展を防禦している。

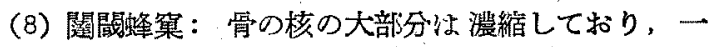
部には消失しているるの゙要る・古い，紋理つ不鮮明な 骨組織の周围に接合線を境にして時代の新しい骨が何回 となく増殖して敊り，従つて鋸雪状つ接合線が多くなつ ている・而も骨は全体としていマトキシリンに淡染して 和り，变性は高度となつている。骨の周团の軟部組織か らは，骨の窩状吸収が僅かなが白認められる部分があ る. 軟部組織の变化は (1)，(3) と同漾汇特異で岕る. 肥厚增殖した上皮層が离り，その下にかなり厚い肉芽の 周がありそその下にニレステッンの結晶を中心にして厚 い肉芽組織の形成が著明で岁り，細胞浸潤が強い。 


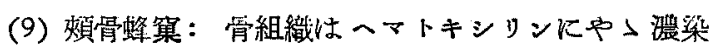
して括り，人管，骨小管を中心にして，文骨壁纪併行す る如く多数の接合線の走行が見られる・接合線は又他の 接合線により切断され，鋸雬状をなしているものが多 ‥骨の核は濃縮しているものも山るが，消失している 所が多く，核の消失した骨小腔が拉大して多北質化して いる所も見られる・骨の紋理は古い骨組織になるに従 い，不鮮明となっている，人管，骨小管の内腔汇は浮腄 が強く，Fibrosis の形成が出り，骨壁より骨の吸収の 見られる部分，類骨組織の形成が認められる部分があ る・文管腔内の高度の浮埂のため，血管が圧迫されてい

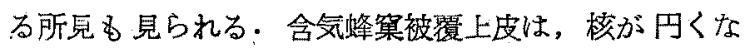

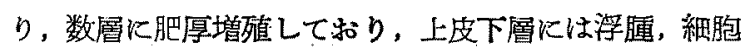
浸潤が認められる. 又 (1)，(3)，(8) 之同样にニレス テリンの結晶を中心とした厚い肉芽組織の形成されてい、 るものがあり，椎血，細胞浸潤が強い。

(10) 後蜂荤列 (山下法)：骨の核は殆どが消失して 特り，紋理は不鮮明となり，骨組織はーマトキシリンに

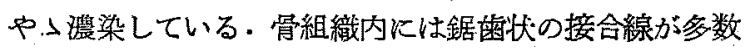
兒られ，過去の破塄治㽷機転を物語っている・变性の高 底のものは紋理も核子消失してしまつて単一な組織似な つている・僅か存在する八管腔内には浮腫ゔ著明であ る・骨の周辺に快肉莱組織が認められるが，この部分よ りの骨の吸收戹完は見られない（1)，(3)，(8)，(9) と同漾にコレステリンンの結晶を中心とした厚い肉芽組織 塊む認められる。

（11）上鼓室：核江濃縮乃至は消失し，粒理の不鮮明 な骨組織内には多数の鋸茵状の接合線の走行が，骨小管 を中心にして，又骨壁以併行して見られる，八管，骨小 管膑に以浮嗹と共儿 Fibrosis が強くなつており，管壁 には新生骨が附加している所見があり，その反対側に心

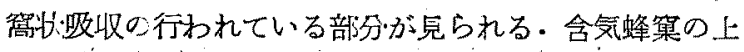

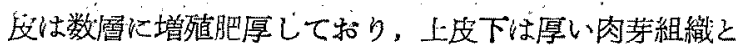

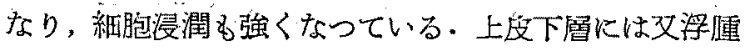
も強くなって物り，この部拡張した血管も認められ る。

術後経過: 右耳術後は 毎日耳内更び耳後創抗生削

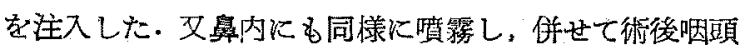
処置を行つた。術後の食然減退と山血のため, 3 回ビタ ミン $\mathrm{B}_{1} \mathrm{C}$ 加ブドー糖の皮下注射を行つた。術後の鼓 膜所㫕の改善讨著しく，右後上部の肥厚，隀涱は減退 し，鼓膜はや小薄くなり，色調が良くなつた。しかし術 後の聴力は機策の悪いためか判然としなからた．右耳
術後 14 日目に左耳の手術を行つた. 右耳之同様水抗生 郕の注入，ガーゼ交换を行つた，術後の鼓膜の或善なや はり著しく，後上部の骨性膨隆は娍少し，緊張部の浸 潤、肥厚が減じてきた。右耳術後24日目にオージォx 一ターで，気導音，骨導音を入れて見だ：気導音ではい ずれる反応しなからたが，骨導音では両耳共に 3000 サ イクルを除く全サイクルで，40〜50db の音を入れると 泣き出した. 㕛この音を小さくす多と泣き止む事が判小 た・術前泣オージオメーダーで音を入れてる反灾はな かったのであるから，聴力が改善されていると考觉られ た・右耳は術後24日目より通気加䞚膜マッサージを行 い，大耳は術後20日目より同椂の治寮を行つた：郝後 創は順調に経過し，退院前には雨鼓膜共火光錐が現かれ た. 右耳術後 38 日目 (左耳術後24日目)に退院したが， その 日家に掃つてから柱時計の音が6 时以後を 告げる そ，3っ目の音がする頃からじつと時計を見詰めるよ5 になつた・㕛手䘕前は元気のない子であつたが，手術後 は非常に元気がよくなつて一時るじうとしていなくなつ た・ 又整形外科炕て先天性股関節脱目はよく入つている のに歩かない訳はないと云われていたが，退院少し前に は陵を立てつ這うようになり；退院後間もなく掫まり歩 きをするようになり，見違えるように発育が良くなつ た。退院後1力月位からラジオの音方し大きくする そ，きよろきよろして音を探す動作が多くなつた・文約 $3 \mathrm{~m}$ 離れて大きな声で○○ちやんと云うと泣き止んて振 り向く・退院後約 2 ケ目に仏壇のチン，チンとい5鐘 の音がかかるようになった・約3.万月目上り食卓台に汁 器を並べる音を立てると，遊んでいて見えない筈なのに すぐ食卓台の方を向き近つ゚いて来る。術後約 2 年目には 約 $3 \mathrm{~m}$ から手を吒くと，振り向いて音を確かめる。家 人は以前に比べると，音に対しては非常に敏感であると 云つていたが，未だ言葉の世界には戻つてこない，两鼓 膜は術前の宿四が消失し，色調は非常に良くなり，光錐

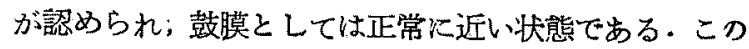
特の槙查は泣き出してしまい，不成功てあった．先 天性股関節脱田に上る歩行困難も，2年後には少し跛て あるが一人で歩行できるようになつた。

第 5 例総括：先天性股関節脱日を持つて生まれた気

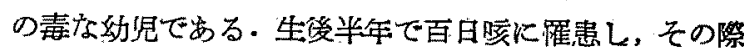
に広義の中耳炎に霍患した。生後 8 カ月頃より音に対し て全く反応しなくなつてしまつた・その後転をとして治 療を受けたが，異常がないとか，2〜3年资でなければ 判らない. 又恒日烼の際に注射したストマなのためだ 
ろらと云われていた・矢天性股関節脱臼の方も，入つ ていると云われながら揤まり歩きもできなかつた.

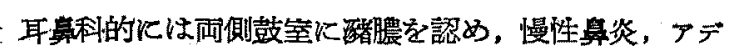
ハイド堌殖症，その他に流涙を認めた。小昌科的には精 神薄弱児ではないか，小昌麻瘦ではないかと云われ，腰 推穿刺を受けたが，全く不明であった.

レ線的には両側慢性側頭骨资が認められた。

本例飞対し 両側口蓋扁桃摘出，アデノトミーを施行 し，先ず耳管からの再感染の原因を除き，耳管を開通せ Lめ，両側保存的儧頭骨炎根治手術を施行し，乳様洞入 口部より上鼓室を経て耳小骨連鎖，鼓室に流下する膿汁

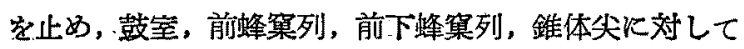
北学抗生物質療法を行つた.

組織学的所見は，右耳の骨組織恔核の脿緮，消失，お るいは骨小腔の拡大，更にこれ等が融合し，多孔質化を 示している・骨質は变性し，璪板の紋理が不鮮明とな り，㴗るい性全体として染まりが悪くなり；更以高度の ものは死骨化している部分もある. 又上前に破壞, 堌殖 老繰り返した所見として，新旧の骨組織が鋸雨状のへマ トキシリン染まる接台線を境として存在している所見 が多数に見られる。

造盛細胞の並列，類兴組織の出現，简状吸収等も見 ら れる。

軟部組織では含気蜂窠炎は上鼓室，乳様洞で最も強 く，上皮の肥厚堌殖，上皮下の細胞浸潤，浮䐺，むるい は器質化が認められる・しかし Fibrosis は未だ著明で はない，又本例に和いては㹨義つ骨鰱炎の所見が非常に 多く見られる・即ち細胞成分·の堌和，細胞浸潤，骨䯣組 織の器質化，周团骨壁に括ける造骨細胞の並列，简伏吸 彼等が見られる。

要するに高度の慢性含気蜂笨炎急性堌悪, 慢性骨炎骨

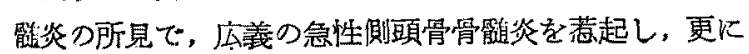
耳管を介しての再感染が繰り返されるために，常に急性 増悪が綝り返されている所見である.

左耳法右耳儿比し骨病変注余り変りはないが，最す特

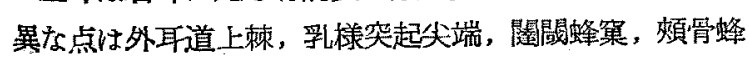

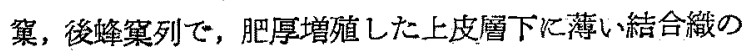
層があり，その下にコレステッンの結晶が多数に，存在 し，その塊を中心にして厚い肉芽組織がこれを取り囲ん でいる：異物型巨大細胞がこの結晶の周囲に多数に現わ れ，組織球，形質細胞，多形䠹白血球が認められる。

㳄火全体として右耳飞比し，骨髄組織が少ない点, 肉 传組織, 器質化による秥:合織が、非常に多い点, 浮腫,
Fibrosis が余り見られない点が異なつている。

スレステリン結晶の出現厄就いては Handschüllexchristian 病も考慮されるがこれだけの検索では断言 する事はできないが，極めて稀代斯かる所見を呈する事 もある事は否めない事実である。

本例は斯かる所見を呈した骨病变が除去されると，先 ず患児は食管が進み，元気になり，精神薄弱坚ではない かと云われた览が見違えるようになり，先天性股関節脱 日で掝まり歩きのできなかつたのが，間もなく诚まり歩 きぶできるようになつた・聴力は言語の世界には戻れな いび，物音に対する聴力は非常に良くなつた。

症 例 6

㭧者：岩○○.4年6 力月. 3

初誩：昭和 31 年 5 月 8 日

主訴：監暨

家族歴：特仁記す事怯ない。

既往歴, 現病歴：生後 1 年半目上り, ウマゥマ, ウモウ (牛)、ト卜（魚); 禾一（僕）等と言い，生後 2 年位でチャーチャし（物母さん），林をマチ，マチ（真 知子) と呼九でいた。 その間生後 1 年 10 力月目化百日 係に䍜患し、ストマイ3本（量不明）の注射を受けたと

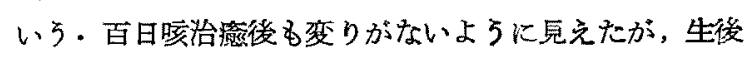
2 年半頃より云ら事山言つても物音㐸次第炕応しなく なつた・それと共炕次第二言葉を忘れて行った・尃門医 上り異常はないと云われたが，生後 3 年 2 ケ月目に某大 学病院でストマイによるものだろうと猃断され、ビタ ン注射をるタ月間行った・しかしこの頃には全然言葉を 発しなくなつた. 生後 4 年 5 カ月目にアデ，トミーを行 つたとい5・更にその1 カ月後には望みはない，歌目た

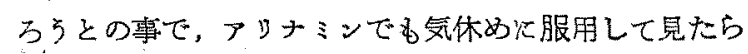
と云われた。

初診時耳科的所㒻：右鼓膜は陷凹が強く，祭張部及 び後上部は浸潤鿱厚していると思われる。弛緩部は浸潤 肥厚している・鼓膜穿刺责行つた所，抵抗が学るが荟出

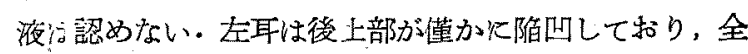
体として浸潤肥厚している・他漏桃肥大が业り，アデ ハイド増殖应も一度手箖老受けているがまだ存在してい b.

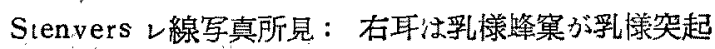
尖端まで発育しているが，一部怯不鮮明となり，一部は

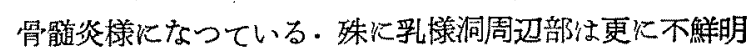
化が著明となつてい.乳羕突起上陵はや小陌凹してい る.後半規管の部分㳡辺绿が明らかではないが，上半規 
管，蝸牛款つ陰影はよく認められる・錐体尖恃倬が不

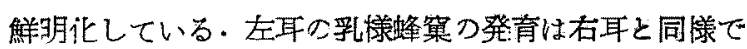
㐫る・乳様突起尖端てけかなり大きな蜂窠が認められる が，辺緑はいずれも不鮮明化している・一部汇は骨髄炎 様となつている部分も認められる・乳漾洞周辺部には小 蜂集群が出り，後半規管，水平半規管附近は不鮮明化が 強い上半規管注認められるが，弓状隆起保高く突出

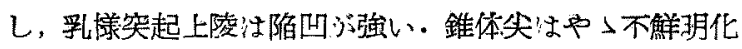
している.

聴力検査老行ったがはつきりしないししかしど5る残 聴はあるよ弓に思われる・而も鼓膜所䙾，レ線写真から 慢性則頭骨炎が存在して扣り，ストマイで片附けてしま 万前汇手街儿上る䧹患骨の除去こそ先決問題である・よ つて下記の如く手術を行った。

昭和 31 年 5 月 14 日両側扁桃摘出更びア゙デノトミー 後, 右保存的側頭骨炎根治手術，5 月 28 日左保存的側 頭骨炎根治手術を行つた。

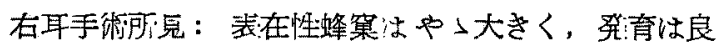
好で票当・蜂䆞刀隔壁は柔らかく, 脆弱となつている

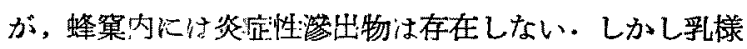
洞に近つくに従い，海淿状となり死兴化が箸明となつて

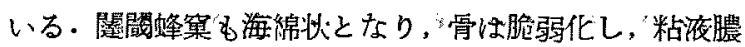
性つ注物ゔ諗められた・後頭顆に達する病窗汢後頭顆

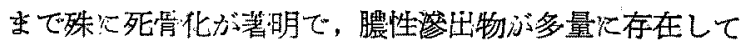

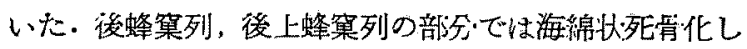
た部宁をを除去後，割合硬い骨組織の下に更见䍜患した小

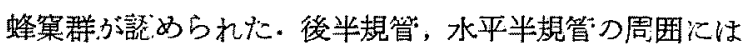
粘液膿性滲出液が認められ，死骨化した骨組織が出り， 迷路周囲部を奇麗に搔爬し，骨性三半規管を露出した。 上鼓案は被復組織が浮腫性を呈していたが，耳小骨は肉 眼的には買常がないので術を了した。

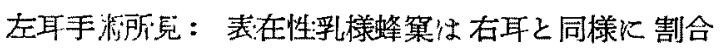

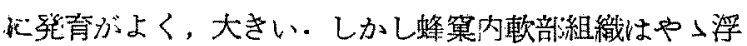
蕾けとなり，乳様洞周囲部注海綿状となり，骨は脆弱と なつて死骨化している部分:ぶ見られる・乳様突起尖端に は大蜂菑が認められたぶ，䗋集隔壁は脆くなり，軟部沮

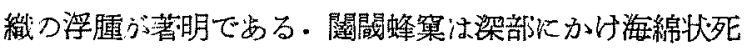
管化していた。煩骨䗋笨，乳様洞は骨が柔らかく脆弱と

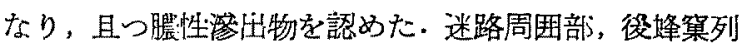
な清掃し，肯性迷路を露出し，上鼓室を撜爬清掃して術 を了した。

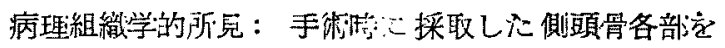
骨軟部共にッェロイジン包旺, 一・重染色, 及文びロ染
色儿より検索した。

\section{右}

（1）外耳道上校：骨組織の核は概小消失し，所々K

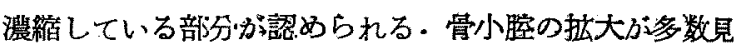
られ，又紋理は大部分が不鮮明とならている・文新汨の 的代つ異なつた骨が隣接して存在し，その接合缐が離断

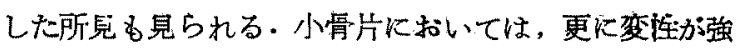
くなつている・八管，骨小管腔にはFibrosis が著明と なつて和り，不整形炕摭大した骨小管火扔いては，血管 胵は拨張しているが胵内は空虚となつているものが多 い. 斯かる不整形心搪大した骨小管つ管壁こは造骨細胞 の並列が見られ，督の新生が周囲化起つている・文变性

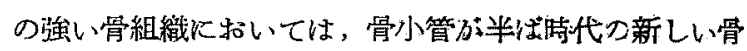
により埋められている所兒も西るが，この時代つ新しい 骨も文变性こ宿つている。他つ部分の骨小管中含気蜂巢 の骨壁からは骨の昍收が起つてお゙り，全体として完ると

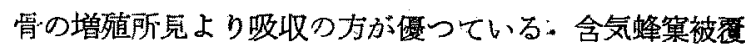
上没は肥厚して和り，上没下沈は浮腫が見られ，一部に は肉芽組織様となつている部分が認められる・結合櫂つ 多い部分では骨の吸収も強い傾向にある・含気腔内には

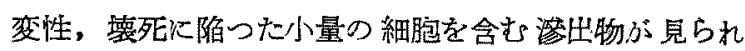
る・骨䯙組織注全く認められないが，骨小管内の軟部組 織には一部脂肪䯘に变化しょうとする所完が見られる。

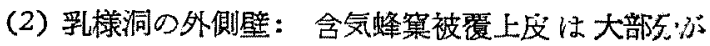
肥厚しており，一部には数層に増殖している部分が完ら れる・上皮下層け厚い結合織となつている所，浮腫の著 明な所るあるが，又肉芽組織㥞になつている所見电多

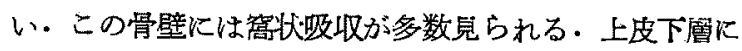
はや〉㹡張した血管があり，細胞浸䦠が 中等度に見ら れ，含気胵内には出血，文び 炎症性㴰出物が 認められ る・古い骨組織においては核は消失し，骨の以前の硪壇 吸収を示して紋理は錯綜して特り，又不然明となつてい

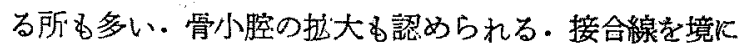
して時代の新しい骨が附加している所にも窝状吸収が㩆 著である。

（3）乳様突起尖端：骨組織は核が大部分消失して括 り，且つ骨小腔は㹡大して和り，紋理は不鮮明となつて いる・又一部の紋理は錯綜している. 又骨小腔の拢大融 合による多孔質化を認める部分も方り，更汇は線䧽㥞化 している部分るある。八管内軟部組織は概小収縮して括 り，骨内膜の部分はーマトキシリンに源染する帯状とな つているすのが多い広義の骨小管て括いては管腔内は

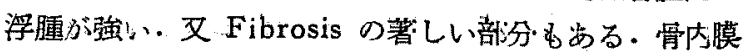


圈の濃染は八管同様てある・一部には造骨細胞の並列し ている部分る、㒻られ，骨新生つ行われている所兒が認め られる・含気蜂䆞泉上皮が肥厚し，上皮下には浮腫が見 られる、叒上皮下㬝は肉莱組織となつている部分も多 い. この骨壁には骨の吸収所見が多く見られる・含気腔 内には炎症性出物が多量て認められる。骨髄腔では脂 肪龍薄が董かながら存在している。

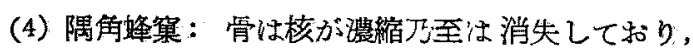
骨小腔の拡大している所があり，紋理は不鮮明となつて いる・一部に特いては変性は更強くなり，骨炑染まり が悪くなり，多孔質化が著明をなっている、八管，骨小 管に括いてい軟部組織はや上収縮している所が多いこ

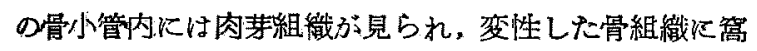
状吸収ぶ行われている。文他つ部分沉は造骨細胞が僅か ながら認められる所がある.合気蜂罙は上皮が肥厚し。 上皮下には浮腫が強くなつている・一部に嚾かながら肉 芽組織が、自られる・含気蜂穼の骨壁ては，鋸歯状刀接合 線意境しして代つ新しい学組織が認められるが，これ

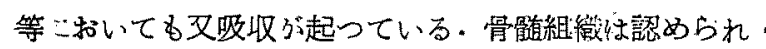
th.

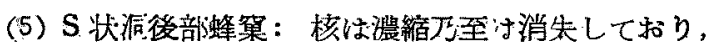
所々に骨小胵も掂大している・玟理は不鮮明の所が多 く：鋸㐘状刀接合線が断続している变怪骨で，この周辺 に注肥厚した肉芽組織か認められる・この軟部組織より 僅が学の破壇吸収が行われている所見が㫕られる・含 気蜂宜，骨的道組織は全く認められない。

(6) 上鼓室の外側壁：大部分の骨は核の消失が顕著 で，紋理は不鮮明となり，骨小胵もやつ搥大しているも のが多い（5）と同樣代断裂した鋸歯状の接合線が多数 認められる。小骨片に扣いては变性の程度は更と強くな つている・これ等の骨に接合楾を境にして持代つ新しい 骨が見られるが，やはり核は消失し，紋理すや」不焦明 化している・軟部組織に接する骨壁には造骨細胞の並列 が完られ，新生骨が鄞かながら認められる・含気蜂窠の 上皮は軽度の肥厚増殖を認めるが, 上皮下の組織, 骨膜 層は概小器貿化されたるのが多い、人管は内腔浮腫つ 認められるもの，半ば増殖骨により埋められているもの 等が少数認められる.

（7）䦮閾蜂笨：骨は核の濃縮乃至心消失しているす のが多く，綮理慒綜し又不解明となっている・この骨 組繶内には異常にーマトキシリンに濃染した接合線も多 数現われている。文骨が多孔質化している所見も僅かな がら諗められる：骨小管及び蜂笨の骨壁からは，骨の筬
状吸収及びそれに伴って造骨細胞の亚列が、見られる類骨 組織及び新生骨が附加している所見が認められる・骨小 管膑には浮腫が強くなっているが，細胞浸潤は殆どな い. 含気蜂菓上皮組織は1〜数層に増殖肥厚して和り， 上皮下には浮腫，結合織の増殖している所見が軽度火認 められる. 又肉芽組織となつている部分もある。

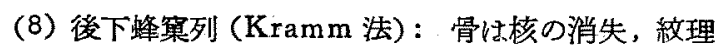
の不鮮明化，染色性つ変化を示す変性つ強いるの，核が 賬縮しており，絞理の錯綜しているもの，又不焦明のも の，核消消失して括り，䎦理が通常と逆に染うている 6の等, 璉々の変性の度合を示す小骨片们分れている。 八管は内腔认浮腫の認められるるの, 内腔の収綰してい るもの等が少り，造骨細胞の見られる部分もある・軟部 組織からは主筒状吸収が行われているが，反刘側俈 骨細胞を伴う骨の新生が僅かながら認められる・軟部っ 上成下層には浮腫が強く，一部は肉芽組織となつて拈 り，上皮は数層に増殖している，骨䯣堙は極めて多い が，骨髄組織の特有の構造仗失われ，浮腫の中骶䯣性 の円形入細胞が点在する所完员呈するものが多い，哭 筫化している部分もあり，この中存在する小骨片は全 く死骨化している.

(9) 後頭顆：骨は核が消失し，紋理は不鮮朋となり， 变性が強い，小骨片のもの程死骨化して就り，ばらばら

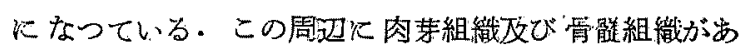
り，僅かながらこの変性骨に吸收が兒られるが，骨つ新 生はない.別か部分飞和いては軟骨組織が完られる。即 ら入り組んだ骨䯣腔の自られる筲組織に接して，軟骨細 胞と共尺軟骨組織が存在している。この軟骨内に八管を 中心にして骨組織に変化しつ১方る部分，3゙認められ，骨 䯠腔に接する軟部組織の部分でる骨比变化している部分 がある・即ち軟骨性化骨がな和認められる・骨髄腔は主

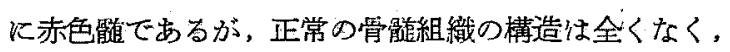
浮尰, 器質化が䜀められる。

(10) 頻骨蜂笨：骨細胞が今までの標本に比べるとや や多くならて特り，核は大部分が濃缩して就り，消失し ているすのは少ない，紋理土不鮮明な所が多く，一部分 は錯綜しており，且つ骨恃緻密化している．この骨組織 には広議の骨小管がや〉多く諗められた・この骨小管腔 内には 1〜2〜3 個の血管が方り，周团恃概小器筫化され て拈り、Fibrosis 6想められる。これ等は公管が骨破 壊により拉大されて，内腔に器質化が起さたものと考克 られるすのが多い，管壁注造骨細胞が並列しており， 周团煌骨の新生が僅かながら認められる。小なる八管 
腔内には浮腫が主に見られる・含気蜂菒被覆上皮は肥厚 し，一部に括いて増殖した所見がある・上皮下尿は軽度 に浮腫が見られ，細胞浸潤が僅かに存在し，肉莱組綏形 成の部分:で細胞浸潤性高度となつている・この骨壁に 如造骨細胞つ並列している所があり，接合線を境にして 新生骨が附加している.

(11) 後㛔寓列 (山下法)：中心をなす古い骨組織は 核の大部分が消失し，紋理は不鮮明となり染まりが悪く なつている.これて接合線を境化して時代の新しい骨が 何回となく附加されており，紋理は錯綜しているが，こ れ等の骨も变性に宿り，軟部組織よりの盆状吸収が随所 に見られる・含気䗋集上皮組織はや〉肥厚しており，上 皮下の浮腫ろ゙著明である・一部には肉芽組織となつてい る所がありこの部に取り囲まれた骨組織は変性む更に

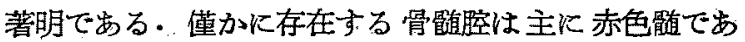
り，周辺火は器質化している部分がある.

\section{左 耳:}

（1）外耳道上柬：核の大部分の消失，紋理の不鮮明 化している骨組織は，一部は骨小腔が融合し，扰大し て多孔質化している部分があり，又染まりが悪くなりば らばらになっているるの, 線維様化しているるのが市 る・骨小管腔には時代の新しい骨が附加して拉り，半ば 骨小管を埋めている文所見である・両者の時代の異なる骨 組織の接合部は殊に離断が甚だしい..八管も同樣に時代 の新しい骨組織により埋められている所完で，中には埋 め尽されたものもある・骨小管腔に恃浮腫及び Fibrosis が強くなり，中心の血管は王迫されているが細胞浸潤は 認められない. 㕛造骨細胞の並列も見られない，器質化 した骨䯣が見られ肉芽組織が混じている赤色䯣である。 含気蜂箸被復上皮はや」肥厚しており，上皮下層の浮腫 は軽度である・文細胞浸潤は殆ど認められない上上皮下 層の一部には結合織が多くなり，器質化された肉芽組織 が見られる・含気蜂巢の骨壁には造骨細胞の並列してい る部分があるが骨新生の行われている部分は少なく，一 方には含気腔内壁及び骨小管内壁より窝状吸収が行わ れ，文の挠に肉芽組織が侵入していつている所見が見ら れる. 含気胵内には古い炎症性出物が認められる.

（2）乳様洞の外側壁：核の消失が著明であり紋理の 不鮮明な骨組織は染まりが悪く、へマトキシリンをや〉 余計に取り, 変性の強い部分では骨の脆弱化を示してば らばらになり，又線維様になつている所もある・又骨小 腔が拉大している部分も認められる・八管，骨小管梳㴶 は時代つ 新しい骨が附加している 所見が多くなつてい
る、管腔内比結合織が多いが，Fibrosis の著明な部 分もある・含気䗋窠の上皮は肥厚して括り，一部《は增 殖している所がある.上皮下には浮腫が強く見られ， Fibrosis があり，軽度见細胞浸潤が認められる・又一 部には上皮が肥厚增殖し，上皮下の組織は全く肉芽状の 所る見られる.この䗋菓の骨壁には主に窝状吸収が見ら れ，骨の新生像は㐷い，骨䯣組織は殆ど認められない。

(3) 乳様突起失端：骨の核の厝縮している所るある が大部分恬消失し，且つ骨小胵は掂大しており多孔質化 をきたしている・皎理は錯綜している部分子見られるが 多くは不鮮明化している，八管腔，骨小管腔にはいずれ も浮蕾が強くなつて扣り Fibrosis がやつ多く認められ る・管壁には骨の破壊吸収機転は認められない、斯かる 機芫は含気蜂集の骨壁に認められる・上皮は肥厚して捛 り，上皮下層には軽度の浮腫があり細胞浸潤が認めら れ，この骨壁に䆚状吸収の像が散見される・これと反対 側の筋肉組織附着部には造骨細胞の並列があり，骨新生が 認められ丈部位によっては简状吸收が起り，骨の表面は 全く粗粘となっている。

（4）隅角蜂笨：核は濃樎或は消失し，紋理の不鮮明 な所が多くなつて叔り一部に於てばらばらになつた骨 組織は全体として染まりが悪くなつている，管を中心 とした时代の新しい骨も変性火樎つている・文脱灰化の 見られる部分すある・含気蜂窂の上皮はや」厚くなり， 上皮下簤には浮腫を認め，軽度の細胞浸潤の認められる 部分がある・この骨壁には造骨細胞の並列が 見られる が，骨の新生所見は少なく，又破壊吸収の所見る殆ど㒛 められない。

（5）䚬部蜂㮤：更飞骨の变性は著明となり，古い骨 組穖は核が殆ど消失し，紋理も不鮮明となり，骨質は無 構造化している. 割合に時代つ新しいと思われる骨組織 もやはり变性が強い，骨壁には造骨絴胞が僅が諗めら れるが，骨の新生像は認められない.含気蜂笨の上皮は や〉肥厚しており，上皮下層の浮腫が著明となり細胞浸 潤が軽庰炕認められる.含気腔内には手術時の出血及び 脱落した上皮細胞が認められる・この含気蜂窠の骨壁に 《学の吸収像が僅か䙺られる。

（6）乳様洞：骨の核は大部分が濃縮して和り；消失 している部分もある・政理はや小認められる所るあるが 殆どは不鮮明となり，且つ骨は脆弱化して和り離断され ている所が多くなつている，広義の骨小管腔には結合織 が多く血管の王迫は著明である。骨小腔つ桩大炕よる多 孔質化就められ，几管を中心とした時代の新しい骨が 
同㨾火変性し，その接合線で離断されている所見も見ら れる・含気蜂窂上皮組織は肥厚しているが，上皮下圓に

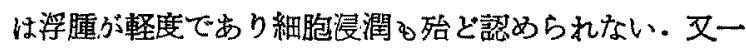
部には器質化が見られる：骨の変性の著しい部分に於て は，骨壁上り简状吸收が見られるが多くない，又造骨細 胞つ並列は見られない。な却含気膑内には手術時の出血 が認められる。

(7) 梁部䦭闒䗋案：骨の变化は極めて高度で核は殆 ど消失し，あるいは骨小腔つ拡大が著明に見られ，效理 は市鮮明となつている. 高度の所では無楧造化してい る・又軟部組織炕取り困まれた小骨片に於てはへマトキ ジンに淡染するのみで死骨化が著明である・八管膑内 軟部組織は収䋧して未り，骨小管腔内には浮腫が強い。 一部力骨小管内《は肉芳組織が見られ，辺緑儿は造骨細 胞つ並列が見られるが，骨新生は認められない，又この

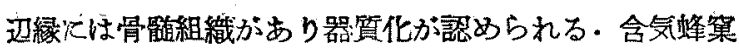
上成組織はやS肥厚し，上皮下には因芽組織の形成が強 く，含気堙内には比較的新しい出物が認められる・含 気蜂笨の骨壁には骨の新生は見られず，文破壊吸収等の 所見も認められない。

(8) 後䗋巢列 (山下法)：骨の変化は極めて高度で核 は殆ど消失し，紋理は不鮮明となつて拉り，あるいは骨 層板の部の染色が悪く，中間がへマトキシリンに却つて 涉染する異常紋理を認め，あるいは該部が笙弱化して骨 組織がばらばらになつている。骨小管膑周边に時代の新 いい骨組織汃見られるが，骨全体はへマトキシリンを薄 くとり変性は著明となつている。骨小管腔には浮腫が強 い. 又上度下層にも同檥に浮腫が強くなつているが細胞 浸潤は殆ど見られない，造骨細胞は僅か火存在するが骨 新生力所見火之しい，破壊吸収の所見は見当らない。

（9）煩骨蜂集：骨の核は大部分が消失しており濃縮 している部分が散在している・紋理は不鮮明となつてい るが骨の変性は最る軽く，エオジンをとつている・他つ 部泣ではエオジンの染色性が減退し，通常とは逆にへマ トナシリンに谈染している部分が殆どである、八管腔, 骨小管腔炕は時代の新しい骨が附加している。この骨小 管腔:軟部組織には浮腫が多く認められ，又結合織の堌 殖つ強いるのがあり Fibrosis む見られる.辺緑には造 骨細胞の並列の見られるるのがあり骨の新生も認められ ら。含気蜂窠被復上皮はや〉肥厚し，上皮下には概小浮 腫が著明で一部々肉芽組織となつている所る見られる。 この骨壁には造骨細胞の並列が見られ骨新生があるが， 又一方に和いては简状吸収更認められる。
術後経過：右耳手術後創内及び耳後創に抗生成注入 を行つた：術後の経過惊良好であつた。手術後 5 日目に 初めて手を吒いて母親を呼えだ・この様な事は生まれて 初めてする仕草であつた・9日目からは注射の時に1タ イ，イタイと声を出す様になつた。以前はたざロア， アだけであつた・がラがラ，カンカン等の音を後かから 聞かせると一生泪命に眼を動かして音の方向を探してい た. 右耳術後 14 日目に左耳を手術した. 術後 12 回 $7 \%$ 重曹水十ビタミン B1 10mg の静注を行つた. 右耳手術 徣 22 日目より通気加鼓膜マッサージを行つた。術後 24 日目に飛行機つ絵を見せるとブーンと声を出す様になつ た・次第に快活となり，他人の泣き真似をしてアーン， アーンと泣いて見せたりした. 右耳手術後29日目にラ ジオの音楽を，音量をや」大きくして約 Im 位敎れた 所より聞かせた所，すぐリズムに乗つて手を振る様炈な つた・左耳手術後 20 日目より左耳通気加鼓膜マッ专一 ジを行つた.この頃約 $3 \mathrm{~m}$ 位離れて後ろより笛を吹く と，两耳火指を当てつうるさいという身振りをする様に なった．右耳手術後70日目頃より訳のわからない言莱 をぶつぶつ言い出した。 ハイとかイタイ等はかなりはつ きり言うのであるが，他の言葉は理解できない，又虎や ライオン等の猛獣の絵を芫せると，頻りにその鳴き声を 真似してロオー等と言つている.更にその後1ヶ月位経 つと約 4〜5m 離れて名前を呼らと振り返り，食事の時 にはゴハンと云うとわかる様になった。

術後 1 年 8 万月目来院時つ聴力検查では 250 3000 廿 ィクルの間は，気導音ては 60〜70db 位の所らしい。 この部位でしきりに眼を動かし，何か言つている。然し はつきりとは測定できない、末だ言語の世界に入る所ま では行かないが，単純な音ならわかるとい5。

第6 例総括： 4 年6 力月の男子. 生後 1 年 10 力月目 に百日晐に䍜患し，生後 2 年半頃より物音に反店しなく なつてしまつた. 生後 3 年 2 カ月に某大学病院にてス卜

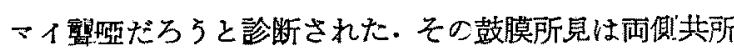
謂広義の中耳加答児，あるいは右側は瘾着性中耳炎等と 診断される敖膜である・レ䠌的には耐側共に慢性儧!頭骨 炎が証明された。

本例儿対して耳管の開通，耳管よりの再感染予防のた め先ず両側扁桃摘出，アデ,トミーを施行し, 即日右保 存的側頭骨炎根治手術を施行した。

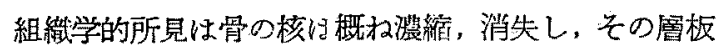
の紋理は不鮮明となり，むるいは骨懕板の染色性变化の ために異常紋理を示し，骨破溒新生のために新旧の時代。 
を異にする骨組織が隣接して存在し，さらに骨が脆弱化 して両者つ接合線が離断され，さらに甚だしい所は骨が ばらばらになつた所見を呈する部位も認められる。八 管，広義つ骨小管においては浮属，Fibrosis，あるいは 器質化が認められ，これ等による血管の王迫が認められ

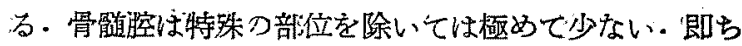

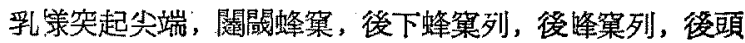
顆こ達する病䈱等である。これ等は概ね炎症に冒されて いる。

含気蜂笨は上皮が肥厚堌殖し，上皮下飞は浮埂，細胞 浸潤が見られ，又上皮下の組織層におけする肉芽組織の発 生, 器筫化が認められる. 含気腔内には变性㯖死飞宿つ た沺胞成分を含を古い、漓出物了洛所火見られる。

含気胵内壁の骨，広義の骨小管の骨壁内面には各所火 一青新生及び 破買か゚見られる。即ち慢性含気蜂笨炎，骨 炎，骨”髄炎の所見である。

2 週間後に保存的側頭骨炎根治手獄を行った左耳は， 右耳儿比して細胞浸潤等つ急性増悪所見は少ないが，骨 病変は强く，骨の染色性引゙覀く、エオジンをとらず却 つてンマトキシทンに淡染する所見を呈する部分が多 く，骨小涳の㹡大融合による多孔翼化，更见高度となり 線維様化している部分も認められる. 文接合質が变化 し，殊:新旧の時代の異なる骨組織の間の接合質が変化 して脆弱化され，骨のばらばらとなる所見が右耳より甚 だしい，骨の新生破壊つ所見も在耳よりは著明である。

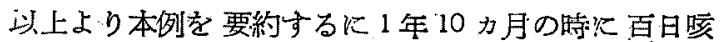
㳊罫患し，その後化学抗生物質があるがため広義の中

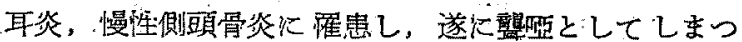
た・斯かる症例は第 2 例，第 5 例と同じく化学抗生物質 が現在程発達していなければ，耳漏が出るからこのよ5 火はならなかつたであろら。

本例に対するストマイ難聴の診断恃更に積極的な診断 の後こレ線検查，鼓膜案刺等の後汇決定せらるべきるの で，化学抗生物留の発達した今日では鼓膜所見のみで斯 かる重大事を決定されては患者がたまらない。軽卒の讙 りを免れない。

原因的治療として扁桃摘出，アデノトミ一後に強力な 化学抗生物䁈療法引゙，慢性側頭骨炎，慢泩乳㨾突起炎汇 ぞの程度の効果を挙げ得るかか問題も右耳の組織学的所 見で自ら明らかである。

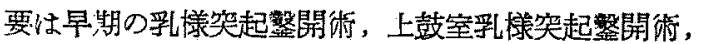
保存的側頭骨炎根治手術のみが斯かる症例を救い得る唯 一つ道である。
本例る言語の世界には戻れないが，音に対しては相当 の感覚を恢復した。

症 例 7

患者：福○年○. 2 年 5 力月.

初診：昭和31年3月19日

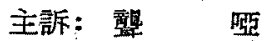

家族歴：特に記す事汕ない。

既往歴, 現病歷：安座で生後発育は順調であこた。 生後7カ月目に健康僈良坚として表彰された。襖，障子 の開閉に目を党し，鳴物類つ玩具で盛んに遊んでいた。 生後 8 力月目麻疹に佐患し, $40^{\circ} \mathrm{C} \cdot \mathrm{k}$ 発熱, かなり衰弱 したが，発熱は 4〜5 日続いた後に下熱し常態に復した。 この後る変りがなかつたし，耼事も気にしなかつた。 生後 1 年目に玩具つピストルが目の前で相当汇強い音を 立てたが眠つていたつで，驚いて專門医を転くとした が, 何れる耳儿異常はないと言われた. 生後1年10力 月目頃より，ウマ，ウマ，バー，バーと云う事誩つ

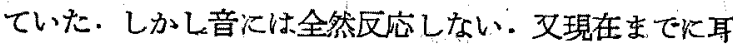
漏に気付いた事るない，某大学病院訪れたが，アデ； 1 ド増殖症なあるが，とれを切除してる聞えるかどうか は判らない。精密検查は5〜6才にならないと出来ない と言われた。

初診时取䄪所見：右鼓膜は祭張部が肥厚し，黄色

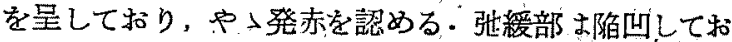
り, 光錐は消失している・左鼓膜はやはり全体が肥厚し でり，更儿発赤を認める：後上部な膨隆肥厚がや小強 く，黄色を呈している・光錐は右耳と同様に消失してい る・両側鼓膜穿刺芫行った所，抵抗が相当に強く，粘液 性膿を両耳に認めた。この嘲は主に白血球であり，双球 菌が慬かに認められたつで，直ちに両耳共に鼓膜切開を 行つた.

Stenvers ᄂ線写真所見：右耳刀乳様蜂䆵怯不鮮明と

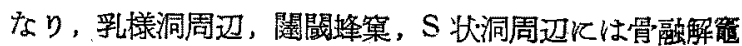
が認められ，全体として骨髄炎樣である.乳様突起上陵 はや小樎凹し，弓状隆起は 突出している，上，後半規 管; 蝸牛豰つ㓌影况認められる・雓体尖は僅かに不鮮明 となっている・左耳つ乳様蜂窠は不鮮明と骨融解の入り 混つた骨殖炎様を呈し，乳様洞周辺恃不鮮明となつてい る. 乳样乫起上陵の宿凹は認められない，上，後半規 管，蝸牛豰の陰影ははつきりしている.錐体尖はやはり 宋鮮明化している.

聴力検查を行つたが; 具体的心記載する事は不可能で あるが，骨導低音部で法何か感ずるようである・しかし 
鼓膜所見，鼓膜穿刺所見，レ楾写真より慢性側頭骨炎て ある事は間違いなく，既往歷よりしてこれが内耳ても作 用を及ぼして，そのため混合性難聴が高度となつてい ると考えられた。

昭和 31 年 3 月 20 日左保存的側頭骨炎根治手術，同年 4 月 3 日右保存的側頭骨炎根治手術を行つた.

左耳手術所見：耳後切開上り入るに，表在性蜂煲は 発育が良好であるが，含気蜂笨被覆組織はは腫脹し，粘液

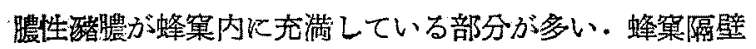
は脆弱となつて括り，乳様洞，磷部蜂策，隅角蜂巢には 硣膿が更に著明で，殆ど全㛔窠を充たしていた，乳様突 起尖端，閣閏蜂菑も同樣で，一部に死骨化した骨組織が 認められた. 乳焃突起上陵骨内板る脆弱化して和り，こ れを広汎に除去, 硬脳膜を露出し, 更々錐体乳様洞周囲 蜂笨を清掃したこの部たは死骨化した骨組織が多く，

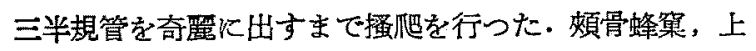
鼓室を播爬し，砧骨短脚周辺を清掃して術を了した。

右耳手術所見：表在性峰巢は発育良好であつた.し かしやはり左耳と同様に合気蜂䆞被覆組䢂は腫脹し, 所 々に粘腹性膿が見られ，乳様洞の外側壁上り乳様洞，上

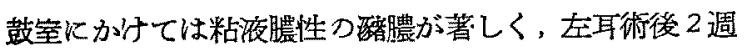
間化学抗生物質療法を行つたつであるが，その限界をう から゙わせた，閶間蜂集，隅俑蜂巢では死骨化している骨 組織が多く，乳䅵突起实端で注粘液性膿と死骨化した骨 組䑸が入り混つている所見であつた・迷路周团蜂集, 更

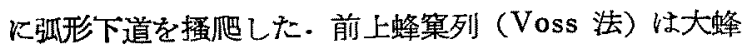

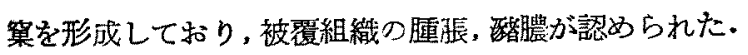
これも搔爬し, 清掃した. 術後, 創内に抗生物資溶液を 注入した所，強い温度性眼振が起つた。

病理組織学的所見：手術時に採取した側頭骨各部交 骨軟部共にッエロイジン包埋, へ・王重染色, 及びワ染

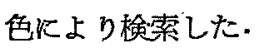

左 耳:

(1) 外耳道上棘：骨の核は大部分がや>濃縮してお り，一部分て消失している所が見られる・又紋理は錯綜 し，あるいは不鮮明となつている・軟部組織に取り团ま れた小骨片においてい，核は殆ど消失しており，紋理は 不鮮明化が著明でへマトキシリンに薄く染まつており， 死骨化している・僅が認められる八管腔内には浮腫が や小強い，骨壁炕はやはり造骨細胞が見られ，時代の新 しい骨により埋められて管腔つ縮小しているるのがあ る. 含気蜂窠被覆上皮は数～10 数層汇肥厚增殖してお り, 上皮下には浮腫, 細胞浸潤が著明である. 又肉芽組
織を形成している部分も多い．含気腔内には炎症性漻出

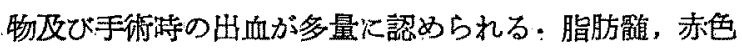
鲔には細胞成分つ增加, 細胞漫潤が認められ，骨噵腔つ 周边部以は骨内膜の肥厚, 器質化が認められる.これ等 の顿部組織つ骨膜圓，骨内膜層に当古部分火は造骨細胞 の並列が見られ，骨の堌殖所見が僅か炕認められる。即 ち慢性含気蜂集炎, 慢性骨炎, 骨髄炎急性増悪の所見で ある。

（2）乳䡕洞の外側壁：骨組織は紋理が不鮮明となり， 核は签縮しており，消失しているものも多い，文骨小腔 の拡大る認められる・文骨はや入脆弱化!てており，断裂 が見られる：この古い骨組織沈へマトキションと浱染す る接合線を境てして时代つ新しい骨が附加されている が，この骨も再び吸収を蒙つている所が見られる・小骨 片に赫いては脱灰化している所，線維㨾化している所等 一般下高婜刀骨病变を起して括り，これ等が肉芽組織に より吸収されている所が認められる・八管は骨刀増殖化 より概小管腔は縮小しており，中には埋め尽されている

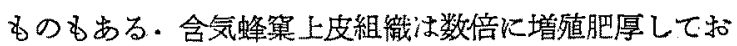
り，上皮直下には細胞浸潤が強い，細胞漫瀾は多形核白 血球, 円形細胞，組織球，形貿細胞等が䛪められる・上 皮下層つ一部沁は浮腫性つ所もあるが，大部分は結合織 乃至は肉芽組織であり，骨力吸収所見が主に見られる。 含気腔内儿は炎症性出物及び手術洔つ壮血が認められ 古。

（3）乳様突起尖端：骨つ核は大部分消失し，紋理は 一部分が不鮮明となり，文錯綜している部分が多い，軟 部は含気腔被覆組織の肉芽で置換されたるのと, 器貿化 された骨髄組織である・この部分ては骨つ禽壮吸収の所 見が多く認められる・骨壁には造骨細胞が僅か諗めら れるが，骨新生は殆ど見られない，器貿化した骨䯠組織 は大部分が赤色䯠である、八管はや>収縮して括り，内 腔飞は肉芽組織の形成が認められる・慢性含気蜂笨炎， 骨炎，骨髄炎で，肉苏形成つ傾向が極めて強い。

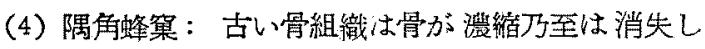
ており゙，紋理江殆ど不焦明となつている・又紋理つ銷綜 が強い部分もある、これ等の古い骨組織内の八管，骨小 管のあるるつは，時代の新しい骨組織汇より埋められて 内腔は縮小して括り，腔内軟部組織は肉芽組織之なつて いる・ 又 Fibrosis る認められる・骨小管つあるもつは 肉莱組織で埋められ，中心細小血管が認められる・そ の管壁には造骨細胞つ並列が見られるが，骨つ新生像は なく, 主江吸収像が認められる・含気蜂笨被覆上皮は 


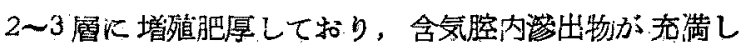
ている・上皮下層にはや小細胞浸潤があり，結合織が強 く增殖し，一部には肉芽組織となつている. 固有層に当 る部分では Fibrosis が強く，骨壁炕は窝优吸収が著し い，骨壁化は奴造骨細胞つ並列している所があるが，骨

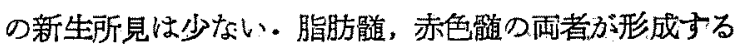
骨賄腔つ骨壁です同様でむり，器贒化している部分が多 くなつている・この部は主に慢性骨炎，骨揈炎の所見で ある。

（5）S 状洞壁：骨の核は灙㜚して招り，消失してい る部分る多く，骨小膑つ拡大が認められる・紋理は不鮮 明となり，接合線つ部分で離断している所見がある・八 管，骨小管には時代つ新しい骨が認められ，管壁には造 骨細抱つ並列している所があり，類骨組織が見られる部 分がある・中には時代つ新しい骨により埋め尽されてい る所もある。管腔内軟部組織汢浮腫性のるのるあるが, 肉芽組織となつているものが多く認められる・赤色艏, 脂肪䯠の両者により形成される骨咀腔はや上細胞成分が 多々, 器質化している所が認められる・骨壁には造骨細 胞の並列があり，骨の新生像が認められるが，他方肉芽 組織による骨の曧状吸収も多くなっている。

（6）鳞部路巢：骨の核恃消失している部分が多くな り，䑤理は錯綜乃至は不鮮明化している・一部分では骨 小腔が㹡大し，多北貿化している所見も見られる・斯か る部位では紋理は殆ど認められなくなつている・合気蜂

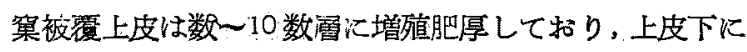
ば沺胞浸潤が多く，浮埂及び肉芽組織つ増殖が著明であ り，又 Fibrosis 認められる・骨膜層の肥厚る著明て ある、骨壁には造骨細胞が僅か儿存在しているが，骨の 新生像は殆ど認められない，因若組織炕よる骨の吸収像 が多くなつている.

（7）乳様洞の天蓋：核が消失している部分が多く， 效理が不鮮明となり，又は錯綜している骨組織に，八

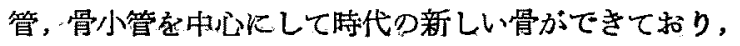
その境界にはへ、トキシリンに謴染する接合線が認めら れる.古い骨組織つ中にはこの鋸荬状をなす接合線が途 切れながら多数見られ，而も幅の広いるのるあり，過去の 骨吸収新生つ機䢂の激しさを物語つている・而も時代の 最も新しい骨組織でも軟部組織より窝状吸収が起つてい る・八管腔，骨小管腔内つ軟部組織は主に肉芽組織とな つているが，管壁には造骨細胞の並列が見られるものが あり，類骨組織により管腔がや>縮小しているむのがあ

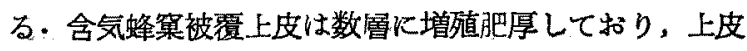

下の細胞浸潤子強い。この部には浮盾つ他火結合織つ 境殖, Fibrosis が多く，一部には因莱組織つ形成が見 られる・殊に Fibrosis は著明であり，骨膜層す高度に 肥厚し，造骨細胞の並列が見られる・この骨壁には新生 骨及び類骨組織つ形成が認められるが，一方に括いて窝

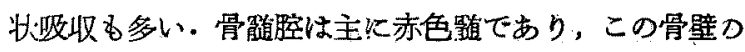
所見む同様である。

（8）外耳道上壁：骨組織は脆弱化して和り，接合線 の部分で離断し，変珄つ程莘の種々な小骨片に分れてい る・即ち八管，骨小管の周辺に見られる增殖骨，核の消 失が見られ，㸚理つ錯綜した骨，骨小腔が拡大して多孔 資化を来たし，紋理つ不明そなつている骨，更に変性が 著しく，脱质化している骨，線維㥆化している骨，染色 性が低下し、一マトキシทンに薄く染まつている骨組織 である・八管，骨小管内腔は概ね肉芽組織であり，内腔 が器貿化している所見も見られる・文封代つ新しい骨組 識火より望められているるのもある.含気蜂巢上皮は数

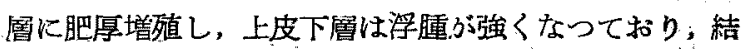
合織つ多い部分や，因芽組織となつている所がある，何 れも細胞浸潤が強く，血管がや子张張している，上皮下

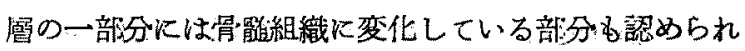
る・斯かる骨壁には造骨細胞が認女られ，骨つ新生所見 と，所々に肉芽組織に上る吸収所見とが入り混つてい る. 慢性含気蜂笨炎，慢性骨炎つ所見であるが，骨の変 化は䀅めて強い。

（9）煩骨峰巢：外耳道上壁と 同様滑は脆弱化して 拉り，接合線刀部分で骨は離断されている．古い骨組織 に括いては核が消失し，骨小腔が拡大して多孔質化をき にしている部分が見られ，紋理が不鮮明となつている が，鍇綜している部分も多い，周囲の小骨片に括いては 強い脱灰及び死骨化の諗められるるのがある，八管踛原 は時代つ新しい骨が見られるが，古い骨組織とは接合線 の部分で離断されている・管腔内には，Fibrosisが見ら れる，広義つ骨小管腔には浮腫が強く，一部には Fibrosis が認められる，管壁には骨新生つ部分が僅があ り，骨の吸収像は殆ど諮められない。含気蜂窂被覆上皮 は数層に肥厚增殖し，上皮下には結合織つ堌殖があり， 細胞漫潤が高良である，骨壁炕は造骨細胞が認められ， 骨の新生像があるが，一方死骨化せる小骨片においてけ 骨の吸収が認められる。

右 耳:

（1）乳嵄突起尖端：骨の核は瀿縮している部分が多

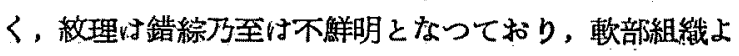


り一方において简状吸収が起り，他方にていマトキショ ンに潭染する接合皤を境にして骨の増殖している所見が 認められる・筋肉組織弣着部においては造骨細胞つ並列 が茪られ，類骨組織も形成されている・広義つ骨小管

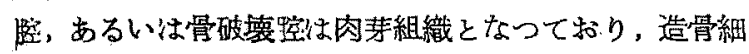
胞が見られるが，骨新生殆ど認められない，含気蜂窂 上皮は2 3 㬝に增殖して和り，上皮下組織は浮䭪が多 い. 矧胞浸潤任軽莨であるが，肉芽組織となっている部 分もある・含気胵内には炎症性㴰出物が認められる。骨 针腔にる浮腫が強く周辺には器資化している部分が見ら 九名。

(2) 隅质蜂集：骨の变化は比較的軽度ではあるが， 核悄消失しているすのが多く，一部のるのは澧縮してい

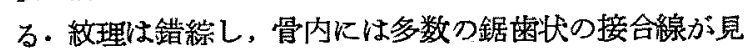
られる・一部の所でハ管周边を除いて紋理が全く不鮮 明となつている・八管はーマトキシリンに湮染する接合 線を境とした時代つ新しい骨により埋められて和り，管

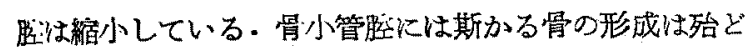
誌められない，管腔内軟部組織は器質化した肉芽組織で

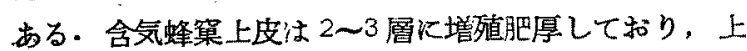
皮下層は浮腫が強く，細胞浸潤が著しい，又上皮下膡が 脂肪䯣に変化している部分が認められる・骨壁には造骨

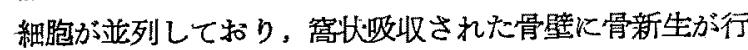
われているが，文䆟状吸収像のみの所もむる・骨䯣腔に は一部器貿化している部分があり，骨壁つ暗分つ变化 るやはり同様の所見を呈している.

（3）S状洞壁より S 状洞後部䗋䆞：骨の核は大部分 が漂維しており，一部は消失している部分があり，骨小

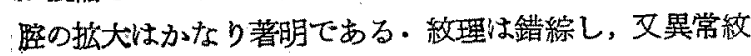
理が現われ，一部分は不鮮明となつている・八管，骨小 管胵内においては浮腫が多く，Fibrosis が認められる。 この骨壁には造骨細胞が見られる所があるが，骨の墥殖 は著明ではない笳肉組織の附着する部分では骨つ窝状

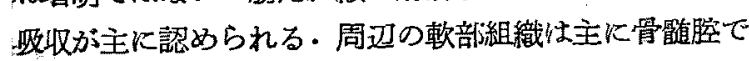
あり，骨の收収像が多い，一部には器質化された部分が 古了。

（4）䚬部蜂窠：骨組織は何回となく破壊堌殖が行わ れてきた事を示して呿り，骨筫内にはへてトキシリンに 漼染する接合線が多数に見られる・古い骨組織程烗の濃 蹜乃至は消失が認められ，紋理る不鮮明となつている。 この骨組織には周囲の骨壁沿って次第に時代つ新しい 骨が加わり，一方に括いては简状吸収る起つている・八 管は骨新生により縮小して和り，管腔内にはFibrosis

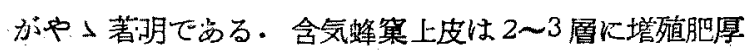

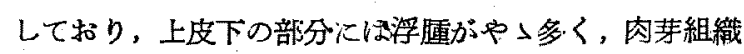
となつている部分もある・この部分つ血管拉掁してお り，軽媵の細胞浸潤が認められる。含気腔内には变性し 江炎症性出物を認める。

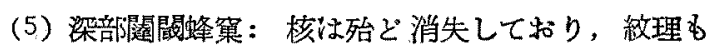
不鮮明となつている骨組織には，接合楾を境にして時代 の新しい骨方附加している。一部の骨には骨小腔の拉大 による多孔質化が認められる・文この骨組織には軟部組

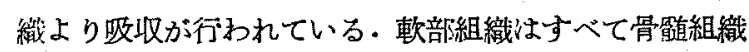
て，細胞成分が増加し，骨壁に近い部分では器質化して いる・骨壁火は造骨紬胞の亚列が僅が諗められるか゚， 骨つ新生治殆ど認められない。

（6）後下蜂笨列：骨の核は消失し，紋理怯不鮮明と なつている・部分的にへマトキシリンに源染する接合線 が認められるが鄞かでする、標本には八管，骨小管等は

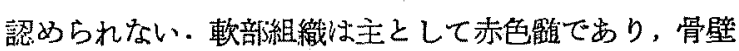
には造骨細胞が漌か沉認められるが，骨の新生所見は認 められず，却って臹壮吸収像が多い。これは殊にばらば らになった死骨化した小骨片に挌いて著しい。

(7) 後, 後上蜂策列：核の消失は殊に小骨片に著し

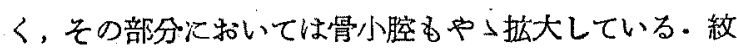
理は鍇綜して叔り，骨内にはーマトキシリンに濃染する 接合線が多数に見られる・殊に骨壁や骨小管附近隹鋸菌 状密なし，又幅の広くなつているるのもある・骨質内下 は高度に脱灰化している部分ぶ斑紋状をなして散在し， この部位つ骨の核は消失している・骨小管腔には Fibrosis が認められ，へ、トキシリンに濃染する接合線な 境にして類骨組線が附加されている・合気蜂案上皮は何 れる肥厚して和り，上皮下層は軽いるのは浮腫を呈して いるが，炎症の強いものは肉芽組織となつている・この

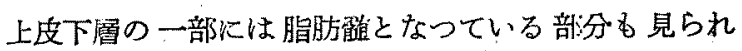
る.骨壁には造骨細胞の並列が見られ，骨の新生が認め られるが，窩状吸収す認められる・軟部組織に取り团ま れている死骨化した小骨片に挌いては殊に吸収は著明で ある・合気腔内は殆ど手術恃つ出血である・

術後経過：左耳手術直後鼓膜の登赤怯消失し, 後上 部つ腫脹が消退し，鼓膜つ肥厚が減少して光錐が僅かな がら現われた。第2例より使用した笛や小石を詰めた空 鑵を使つて色々音を出した所，眼学動かし，首を動かし てアー、アーと云つていた。この年令は一番手に負えな い年頃でもあり，殊に可愛がられていたつめか術後つ安 静は思らに任せず，復かせでくのに苦心した・術啳療 
法は今までの症例火記した如くに行った・左耳術後 14 日目に右耳の手術を行つた・術後抗生剂つ注入を行つた 所，温重性眼浱が著朋で，内耳はをだ機能つある事がは つきりした・術後一旦回复した鼓膜は日を追 5 に徉い， 再び肥厚をきたし，時々発赤も現れた。これは安静を 守れず，ガ一ゼを自分で取り出して，指を入れたりした ためと思われる。このため経過が長引き，再び回復する のに手間取つた・左耳術後 33 日目より通気加鼓膜マッ サージを行い，右耳は術後30日目より行つた．この頃 漸く両耳共火鼓膜洅び光錐が現われた. 㕛手を吒くと 約 $1 \mathrm{~m}$ 位で振り向く事が多くなつた. 左耳手術後 41 日 目オージオメーターにより純音を入れて見で、気導では 反応しないが，骨尊は 2000〜4000サイタルで, $45 \mathrm{db}$ 位 上り泣き出す. 左耳術後 48 日目に飛行機（遠方を5台） の爆音が聞えたようで指さして見ろという：5m 位離れ て大声で呼ぶと振り返り，術後50日目再聴険つ際儿は 気導では全サイクルにわたり，最大䦪值て眼を盛んに動 かす，骨導では前回と同様に泣き出した.片言を゙少し言 ろ事があり，鼓膜る後上部刀腫掁が消失り，肥厚子消 失，光錐がかなりはつきり認められ，や>混濁が残るの みとなつた・術後的 5 ケ月目感冒後儿来院した時に, 左 鼓膜が肥厚著明で光錐消失し，鼓膜穿刺えより粘液血性 出液認めた。しかし鼓膜切開注行わず祯力保存的に 治療を行つた。この后の聴力検查では気導音は500〜 2000サイクルでは最大間值で聞えるよ5で，しきりに眼 を動かし，骨導でも最大間值で同捸であつた，両耳鼓膜 マッサージを約 2 カ月半行い，又アリナミン $220 \mathrm{mg}$ を 使用してみた。飛行機の爆音は聞えるよ5で，先漖え たり，片言らしい事は云つているが，どうしてる言葉の 世界に入る事はできなかっ・

第 7 例総括： 2 年 5 カ月の男児, 生後 8 ケ月目に麻

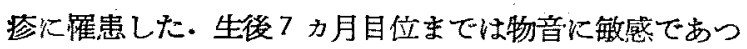
たが，1年目には全く反応しない事に気付いた・某大学 病院を訪れたが 5〜6才にならないと精密検查は不可能 と云われた。

鼓膜は両側共に肥厚し，僅か火発赤し，何物かつ存在 を思わせる鼓膜ですつた・鼓膜穿刺により粘液性膿の殫 溜を証明した・レ線撮影により两側々頭骨炎が証明され た.

組織学的には骨の核は濃縮むるいは消失し，更に骨小 腔の脑大している部分もある・骨層板の紋理は概才不鮮 明となり，あるい畒骨層板の部肪梁色性が悪くなり，中 間部が却らてへマトキシリン安とり, 異常紋理を呈して
いる部むある・又死骨化して腾くぺマトキションに焱染 している部分，又高隻炕变性し線維様化を示している部 分むある・あるいは以前に破壊, 新生を示す時代の異な つた骨が相接して存在し，その間の鋸䨑状の接合線がへ マトキシリンに比較的溇染している部分もある. 又これ 等つ接合線つ部分引゙変性し，脆弱化し骨がばらばらにな つている部分もある。

八管腟内には浮腫，Fibrosis を認め. 又肉芽で埋め られているるの，新生骨で埋められているるのるある。 これより大なる骨小管臸，骨破壊腔も同様な所見で る.

含気腔被覆上皮は数圈あるいはそれ以上《肥厚堌殖し て括り，上皮下には浮腫，細胞浸潤，肉芽堌殖等を示 し，骨膜層にも肥厚が誌められる。

これ等の乾部組織と骨組織つ境㐳は造骨細胞つ並列, 類骨組織，新生骨を認める部分むおり，他方には骨吸収 の所見が認められる部分るある。

骨䯣組織法外耳道上棘，乳様突起尖端， $\mathrm{S}$ 状洞壁，乳 様洞天蓋等に認められ，脂肪䯣は少なく，赤色霍が多い が，何れる炎症性変化を蒙り，器質化されている部分も おる・骨内膜層の肥厚, 周辺の骨壦殖, 破壊を認める部 分るある。

右耳るほ心゙同樣の所見であるが，骨病変汢更に強い。 以上を要約する組織学的には高度の慢性含気蜂巢炎

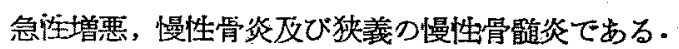

鼓膜所見はアデノィドを有する幼児によく見られる鼓 膜であり, 中耳加答児, 軽度か中耳炎と詪断される・レ 線所見でも含気化抑制と考鼻る人すいる：しかし実際に はその組織学的所見が示す如く慢性含気蜂窗炎急性增 悪, 慢性骨炎, 慢性骨髄炎である。

斯かる所見を両側々頭骨化所有している時洗ず第!

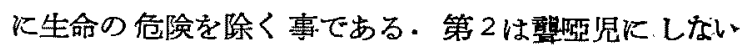
事, 第 3 は鼓膜に慢性化の所見を作らない事である・精 密検查つできる 5〜6才を待つていてはこの3つの治療 の目的は何れも達せられない。

本例つ両耳儿対し 保存的側頭兴炎根治手術を地行し た.しかし患児は最も理解つ贯い年令であり，両親が判 らぬため火術後の安静が保でず，苦心したが，一応は光 錐, 光沢のむる鼓膜にし, 言語修得沈は不足てあるが, 音に対する聴力は大分出た．しかし5っ月後に感冒後 に再来院した時は再び鼓室に渚膿を㒛めた：その啳通気 療法を行つたが，言語修得可能な聴力は得られながら た. 


\section{第 3 章 絵括並びに考按}

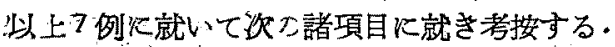

（1）鼓膜所見を総括するに鼓膜所見が正常なるのは 1 峢もない，所謂慢性穿孔性中耳炎は第3 例っみで，その 政膜は両側綤張部の全穿孔である。

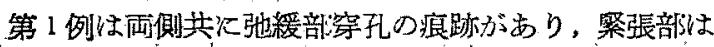
光沢を欠き，少しく黄色味を帯び，所䜋中耳加答児とし て鼓膜穿刺，耳管通気をする鼓膜である・しかし本例右 耳は通気をしながら繁になつてしまつた。

第2 例徒化学抗生物筫療法水上り耳漏が止采机ば所謂 中耳炎が癒つたとして，斯かる不完全な治㞠を繰り返さ 执た鼓膜である：即ち masking effect の最覀の症例 である.

第 4 例 了解すれば更汇早期化手術できた应例である.

第 5 例子鼓膜祭张部つ浸潤，肥厚，後上部発赤，鼓膜 穿刺で多量つ血性膿を証明されている・即ち第2 例とは 添同様である。

第 6 例は右側は陷凹が強く，祭張部瘉着，後上部浸潤

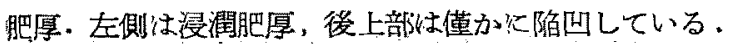

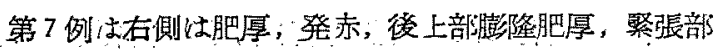
や小黄色を呈し，左側もほら゙同様である。

以上より考按する化第 3 例を除き，裁膜所見とそつ聴

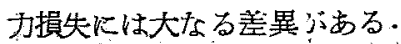

化学抗生物質の無かつた時代には斯かる側頭骨の病変

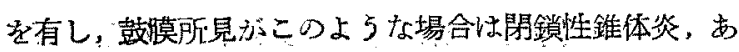
るいは乳樣突起の病变が肉䓔墙殖こより閉鎖珄となつて

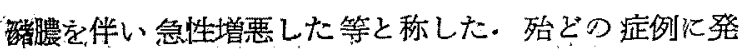
熱，疼痛，その他つ症状字伴った：徒って鼓膜切開を受 けたり，乳㨾突起鳌開術を受けたり，錐体手術を受けた りした:

即ち憼咞になってみれば，却って抗生物質等がない時 代ならば，耳漏が出るからあるいは明示型の乳样突起 炎，錐体炎となり，生命つ危除な症状を現すから，早

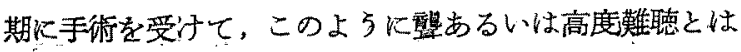
ならなかつたかる知れない。

“要は抗生物質山現後は鼓膜所見で発浾等の急性期の症

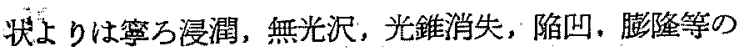
症状が大切であり，殊火軽卒なストマイ難德の診断を受

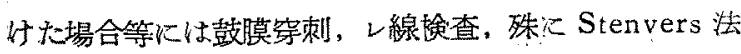
の所見が大切である.

Masking effertなる言葉隹疼，発熱等の苦痛を隠 蔽し，鼓膜所見，組織学的所見では急性増悪を減じ，病
気を固めるもので，病霆を摘出する手術と混同してはな らない，殊儿これ等の総てを棚上け゚して，ストマイ難聴 の診断を下すに抌いては軽卒も甚だしい。

（2）推定発病年月日より手術迄の期間は第 1 例左耳 20 年, 右耳 10 年, 第 2 例 5 年 10 力月，第3例 28 年， 第 4 例 1 年 5 力月，第 5 例 2 年，第 6 例 2 年半, 第 7 例 1 年 9 カ月である。

即ち第 1 例は所謂滀出性中耳加答児を䊝り返す中に，

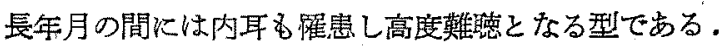
第3 例は最子本邦に多い型で，耳漏が頻回の急性增悪に より出たり止まつたりを繰り返す中に，初めは伝音型難 聴が次第て混合型となり，而も長年月の間専門医の治潦 を受けながら殆ど㻎となつてしまう。即ち生命の危除を 除くための手術は莧物の発達した今日では遅くてるよい が，一度慢性となつて 30db 以下になつた場合は，そ れが聴力即ら機能つ保持回復を目的とする手術つ場合に は，一側でもよいから一日も早く行うべきである・即ら 虫霜に譬えれば早期に根管が侵されぬ中にインレーで治 療し得る時期に治豦して括く事が大印である。

第2 例はその経過の中途に不圭にしてストマイ難聴，

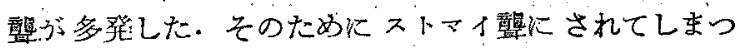
た.しかし手術交び組織学的に前述の所見が証明され， 術浚前述の珓き聴力改善が証明された事はストマイ憼で なかった事を明らかルしている。

第 4 例以下も同様である.

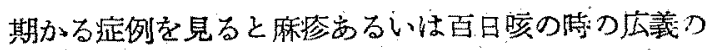
中耳炎，側頭骨炎を手術をしないで楽剂で納めた事は非 常な不幸を招いた。乳奻児期です適時の上鼓室，乳㥞突

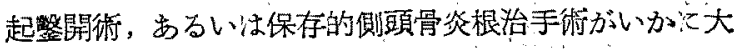
切かが判る・要法抗生物質による鼓膜所見の好轱に欺さ れない事が大切である。

（3）上線所見：仁保，高畑，岩武 ${ }^{35}$ (1952) は日本

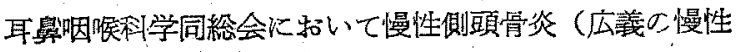
中耳炎) D Stenvers 法レ線所見に就いて述べ，その 所見と組織学的所見を説明し， Verschleierung，Osteomyelitisch, Einschmelzungsherd, Sklerosierung の 4 に分類した。

又従来称えられた所謂慢性中耳炎の際の含気化抑制 は，組織学的に証明せられた慢性骨䯘炎が続行するがた わに含気蜂巢の発育及び再生が阻碍されて起るすので， 従来は慢性骨炎骨䯣炎が等䦥に附されていたと述ぺた。

高烟 ${ }^{36)}$ (1953)は所謂慢性中耳炎の 104 例の Stenvers 法レ線像に就いて記載し，全列に病変の存在志認めた。 
翻つて本症例に就いて総括するに第 1 例左耳は全体に 骨䯣炎様，右耳屯骨䯣炎様。第 2 例左耳雓体尖，S 状 洞周囲骨触解，迷路周囲，乳様突起尖端不鮮明，三半規 管不鮮明. 右耳は全体に不解明. 第 3 例左耳泩全体に不

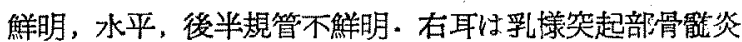

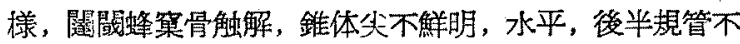
椫明. 第 4 例左耳性全体儿不鮮明，乳様突起一部骨䯣炎

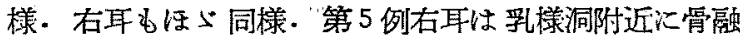

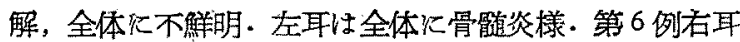
は乳様突起部不鮮明，一部骨韧道炎様，錐体尖僅加火不鮮 明. 左耳的乳嵄突起部不鮮明，一部骨的道炎様，錐体尖や $>$ 不解明. 第 7 例左耳は全体飞骨䯣炎様. 右耳乳㥆突起 部滑髄炎様，錐体尖僅汃次不鮮明.

而して第 1 例，第 3 例と他つ幼児のレ線写真とを刘此 するに，長年月を経過したるのは硬い感じが強く，幼呪 では軟らかい感がする。

次火弓状隆起が高く，乳様突起部上陵が归四している 所見，即ち手術時に遭遇する危除性側頭骨の 所見は，第 $1 ， 2$ 例両耳に，又軽度つものでは第 4 例左耳，第 5 例右 耳，第 6 例左耳，第 7 例右耳儿認めた・斯かる乳㨾突起 は全体の夫いさむ小さい。

斯かる所見は慢性骨炎，骨骨道炎の急性時あるいは慢性 绩性増悪時灯含気蜂巢被覆上皮恃脱落消失し，軽い時沈 再生するが，重症の時は一部しか再生せず，又そつ後る 慢性骨炎，骨咀炎上では通常の含気蜂窠つ登育も遂げら れず，乳㨾突起自身す通常の発育が遂げられない。

先天的任含気型，混合型，繳密型むむるが，斯かる重 症例飞执いては先天的の成分上りは慢性骨炎骨䯣炎の演 ずる役割りは遥か心大きい。

乳様突起自体つ発育が悪ければ; 手術時に外耳道後壁 涂斜めとなり，S 状洞は前方位をとり，中頭蓋简底虫 位をとるのは当然である・脳，内耳等は先燈育遂げ るが，乳様突起等性顔面頭蓋と共儿成長する。矢の成長 が慢性骨炎，骨䯣炎のために阻碍される・促来の耳奥科 では含気胵学説が余りにひ冓要視されて，斯かる胃地に 立つての篗察が余りなされなかつた。

（4）手術々式：所謂中耳炎，側頭骨含気蜂窠炎の発 生は，耳管より起炎菌あるいは起炎物が鼓室に入る事代 よる・従つて乳幼児に和いてはその原因の大部分をなす アデノイド切除，扁桃摘出，及び副鼻腔炎の治療が大汤 で山る. 即ち第 $4,5,6$ 例に行った．第 4 例は 2 年 6 ケ 月で扁桃摘出，アデノイド切除を行つた・この手術は乳 幼児では耳を慢性化させないため熶も大切な原因的治
療で，生後10 カ月位から行ら事ができる・アデノイド切 除つみでもよい場合すあるが，㶡者を併用すれば更によ

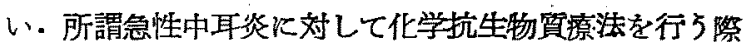
に，経過が遷延し，鼓膜に肥厚が現れ，ながなか光沢 の回復してこない場合，あるいは頻回に繰り返す場合に は，扁桃，フデイドに病気があれば，これ等を除去す ると良い場合が沢山ある。

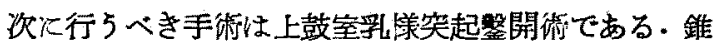
体前上，後上，後，後下蜂黛列，あるいは後頭顆に達す る病竅があれば保存的側頭骨炎根治手術が良い。この手 術は浅在性側頭骨病䆝及び伝音系を保存して除去し得る 錐体病酉を除去し，その結果としては乳様洞，上鼓堂を 経て耳小骨連鎖に降りかつる膿汁を止め，鼓室，前下， 前蜂窂列，錐体尖火対して化学抗生物質潦法を行い，鼓 室即ち鼓膜，耳小骨連鎖の病変の慢性化を防き；あるい は慢性化した所見を固めるのに最す重要な手術である。

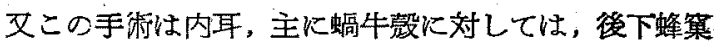
列み゙広く内方に蝸牛䧫の下面に拉大している時があるの でここの場合は蝸牛殻の減荷にるなる。三半規管に対し ての減荷手術はこの手術て概ねその目的が達せられる。 この手術を施行したつは第 1 例右耳，第 2 例右耳（水平 半規管切除術を併用)，第 4, 5, 6,7 例の而耳である.

而して部膜の混濁，石兏沈着，洀疸等の恢復不能の所 見は止むを得ないが，概文光錐，あるい统光反射のあ る，浸潤肥厚のない鼓膜とする事ができた。

これ等の症例は主に未だ年令る少なく，正確な聴力検 查も不可能であるので，一応致膜，耳小骨連鎖を修復 し，鼓膜所見の慢性化を防き，経過篗察中であり，将来 側頭骨炎根洽手術に直す可能性を保留してある。

第 1 例左耳，第 2 例左耳，第 3 例両耳に対しては側頭 管炎根治手術及び内耳手術を行つた．斯かる側頭骨内の 骨病变を徹底的他除くには側頭骨炎根治手術が最すよい 事は明らかである・しかし内耳内に病変のある場合は更 に斯かる手街の組合せが必要である。

1957 年ワシントンに括ける第 6 回国際耳鼻科学会に 特いて仁保，安田 ${ }^{12)}$ は斯かる際つ内耳手術を下記の如 く分類して報告した：

i）迷路周囲部の罹患骨除去

ii) 開 空 術
A) 膜様迷路D露出
B）外淋巴腔の開放

iii）部分的半規管切除術

A）半規管内の肉芽組織学健康部に至るまで除去 
B）卵形唗に至るまでの肉芽組織の除去

C) 慢性炎症による半規管内腔の消失

a) 死骨化骨組織

b) 緻密骨組織

即ち第 1 例は開空術，第 2 例は部分切除街，第 3 例 6 部分切除術を施行した.

(5) 組織学的所見:

（a）含気蜂笨炎：20年を経過した第 1 例左耳に拉い ては隅角蜂杲に立方状又は円柱上皮様の小含気腔が 1 個 認められたのみである.10年を経過した右耳に和いて は乳様洞の外側壁に上皮は1〜数層に增殖し，上皮下に は浮通を認める含気蜂窗を認めたつみである。

28 年を経過した第 3 例左耳に和いても乳様洞の.上皮 下浮婳，肉苇粗織を認める含気蜂集を認め，その他上

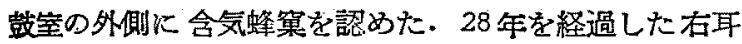

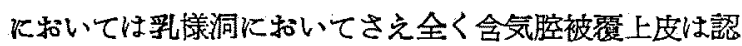
めなかつた。

5 年 10 カ月を経過した第 2 例左耳においては隅角蜂

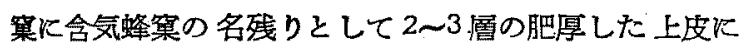

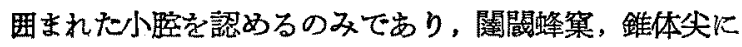

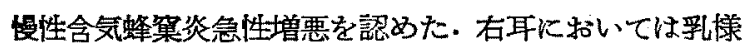
洞, 乳様洞の外側壁, 及び後蜂集列迷路周囲部に認め た.

1 年 5 力月の第 4 例， 2 年刀第 5 例， 2 年半の第 6 例. 1 年 9 カ月の第 7 例では含気蜂巢のあるべき部分火は程 度の崖こそあれ，殆どの部に慢性含気蜂荤炎あるいはと れの急性増悪の所見を認めた。

即ら奻持期には相当高度で慢性含気蜂䆞炎，慢性骨 炎，骨殂道炎の所見であるが，その後嫴膜所見が出性中 耳加答胃，慢性穿孔性中耳炎であうてる骨炎骨酭炎が持 絸する時は上皮細胞は消失し，含気蜂窼炎の所見は消失 する事すある事か判明した。

斯かる合気蜂集は上皮は背が高くなり，立方上皮とな

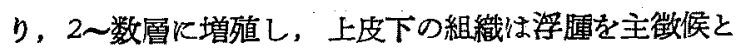

し，急性増覀時沉は円形細胞，多形核白血球，形質細 胞，組織球等の細胞漫潤が現れ，稀仔好酸球の現れる事 あある。その他結合織細胞, Fibrosis が現れる・又上 皮下の組織層が肉芽組織となり，あるいは器質化されて いる場合るする。

骨膜層は肥厚し，上皮下の㬝との区別が明らか判る 時もあるが，不明瞭の場合もある・

この両者から成る浮腫性，Fibrosis を示す組織には 脂肪蹃が現れる事がある。
骨膜層と骨との境汢造骨細胞つ並列，破骨細胞つ出現 等骨の破壊，吸収，堌殖等の変化の現れる部である.

而して最も大切な事は病的骨の上には正常な合気䗋集 被覆組織は存在し得ない事である。

第 5 例左耳の外耳道上棘附近, 孚様突起尖端, 閣閶蜂 柋，煩骨蜂穼，挠蜂窠列に現れたコレステリンの結晶 に就いては，斯かる症例は極めて稀であるために，更に 症例を重ねる迄は決論を下寸事は避り度い:しかし本例 が精薄児の疑いの診断を受けたり，術前迄は悬汁過多，

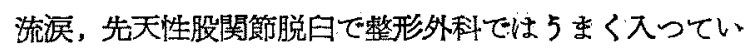
るから歩けない訳はないと云われても，㨔まり歩きる できなかつたりした事を考光る時は，Hand Schüller Christian 病と関係が岁るかる知れない.

(b) 骨組織：20 年, 10 年，28 年を経過した第 1,3 例に扣いては骨の変性が極めて強く，核の消失，紋理不 鮮明, 異常紋理の出現, 文染色性が变化してへマトキシ リンを多くとり，あるい染色性が極めて悪く，死骨化 が見られ，文骨小腔が拉大し，岕るい瀜合して多孔質 化が見られる. 文骨基質が溶解して線䧽樣化を示してい る・接合質の变化も極めて強く，骨の脆弱化も著明であ る。

広義の骨小管は極めて多く，従つて Osteoporoseを

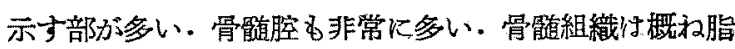
肪䯣である・八管，骨小管，骨䯣胵の骨内膜は肥厚し， ーマトキシリンを多くとつている・八管，骨小管の中央 には多くは血管があり，周囲性浮腫性あるいは器質化さ れた結合織で，多くはFibrosis 老伴い，中心の血管が 壬迫された所見を呈している。

いかに側頭骨炕先天性の含気型，混合型，緻密型があ るとしても，斯かる变化をきたす事はない。

即ち偩!浢冎の病变は慢性化し，頻回の急性増覀のため に含気蜂笨は消失し，骨の破壊新生を繰り返した所見で ある・保等は斯かる所見を約 10 年間，破罗新生の繰 り返しが慢性貸頭骨炎の組織学的所見である事索数回に 涉り，日耳鼻総会，むるい関東地方会において述べ た・最近吉田 ${ }^{45)}$ はこれを Anbau, Umbau, Abbau なる表現で発表した。

斯かる骨組織つ新生破壊を釋り返すための体液循環を 司るのが，極めて多数化見られる広義の骨小管，骨䯣腔 である。

而して斯かる高度難德者ではなく，60〜70db 位迄の 慢性側頭骨炎では肉来堌殖，骨新生，類骨組織，骨吸収 等の修復機枟が粪が多く見られる。この2例では斯か 


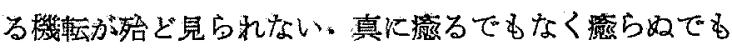
なく，骨病变は軟部の治澺を遷延せしめ，軟部の体液循

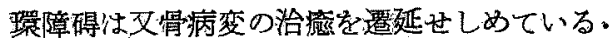

通常の慢性側頭骨炎では，急性増笖部老除けは軟部組 織之骨病変は概小平衡が保たれている・又これ㕫慢性化 であり，即ち病的骨の止飞は正常な含気䗋笨被㠅組織的 存在する事性なく，骨膜層は肥厚し，上度下の畨は腫掁 し，上投綀胞土背が高くなつている・即ち一度慢性化し た場合は通常の含気蜂窼の発育は阻碍される・

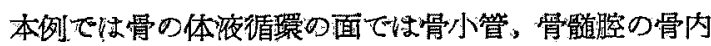

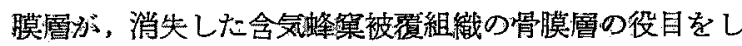

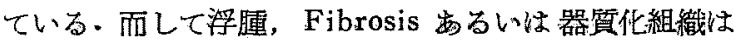

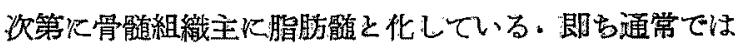
脂肪籍等の見られない所に見られるのは斯かる機序によ る.

5 年10 力月の第2 例炕去いては第 1 例，第3例より

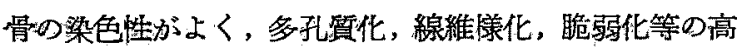
淁の変性所見は，その程度が軽い。しかし骨の死骨化， 骨增殖，骨昅収等の所見注強い。

1 年 5 力月の第 4 例，2 年つ第 5 例， 2 年半の第6 例， 1 年 9 カ月の第 7 例等の 慢性含気蜂笨炎ちるいはその急 性増覀所㫕は強く, 㕛肉芽の増殖, 造骨細胞の並列, 骨 新生，也るいは曧状吸取等を認めるが，骨の染色性，骨

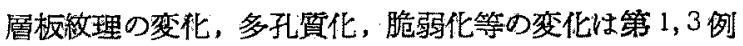

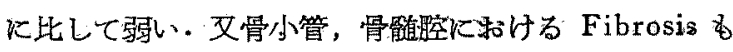

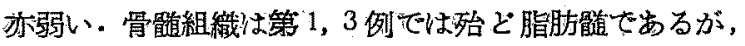
これ等の症例では赩䯣がかなり認められる。これは年 令の相違，時代の相違と考它られる.

(6) 内耳胃病変：第2 例左耳上半規管附近の標本 快膜様半規管を含み，内淋巴腔は空虚であるが，外淋巴

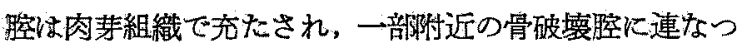

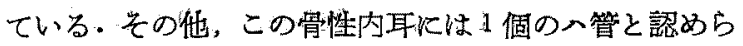
れるるの，5個の骨破壊腔の慢性化炕よつてできた骨小 管か諗如らる。

即ち骨性内耳の如き栋密骨子，斯かる長期の急性增要

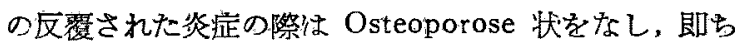
炎症儿侵された外淋巴腔は側頃骨炎, 含気蜂杲资々交通 するК到る事むある。

本耳の水平，後半規管的轚除したが，管腔も認められ ず，眩最もなかつた，上半覞管の上半部る同様であつ た・斯かる所見は，内腔が新生骨で埋められた所見であ る.

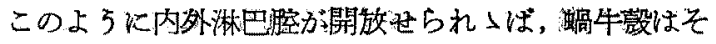

の重王から開做せられ，之の笺存機能がある程率回復し

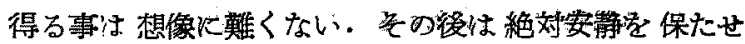
て，化学抗生物質を使用し，開放せられた内耳文の再感 染を防げばよい。

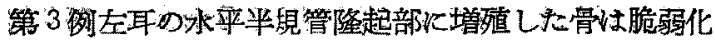
が甚だしく，変性も極めて高度で来来の繳㮫な滑性内耳 の骨組織とは似ても似つかぬすのをなつてる。不整形

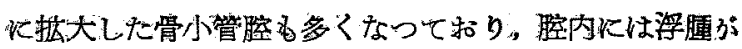
強い.

この組織の下の膜様水平半規管は黄色を呈していた。 恐らく組織学的には前者と似たようなるのだろう。こ

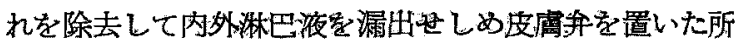

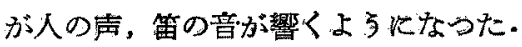

即ち斯かる焱症比侵された骨，炎症信侵された限局性 の内耳炎除志执ば，その重圧加開放されて，残存 した蝸牛殼の機能がある程唼回復し得る事が証明され た.

この問題に就いては仁保，安田 ${ }^{193}$ 43) $^{43956,1958) ~ は ~}$ 既行第6 回国際耳鼻科学会々の他で発表した.

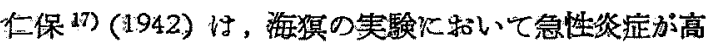
度の時は両网空上りの内耳感染が多く，中等度の時は病 義の骨小管方りの感染す考慮すべきであり，㘝蛸牛の尖 端，三半規管の一部等们起る事つある限局性獎液性内耳 炎炕和いて性，広義の骨小管上りの感染る教慮すべき事 を提唱した。

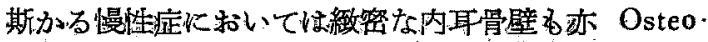
porose 上5の变化を現す事るある事が証明きれた。

著者 49) (1956) 性斯加る 炎症が 水平半規管内儿波及 し, 更に卵形整を侵した症例の手術時炕搔爬した内耳内 の肉莱組織の 組織学的所見赏関東地方会 28 回大会厄発 表した。

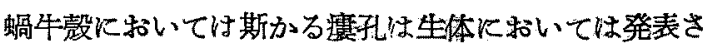
れていないが，死後の組織学的検索に拉いては Eggston, Wolff ${ }^{1)}$ (1947) Kる記載されている.

即方斯かる骨組織が第 1，3例の如く長年月の間蟥牛 設に喽接して存在する時性，内耳骨壁にも斯かる变化を

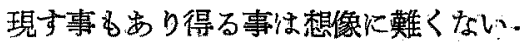

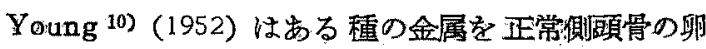
円空に注入して，おる压をかけて外淋巴胵と内耳周囲と の淋巴管の交通の存在する事証明した。

翻つて内耳孝灌流する血管性佐藤 ${ }^{31)}$ 飞上れば内耳道 孔上り聴神経，顏面神経と共にこれ等に沿りて入る鍋谷 32）の所謂迷路動脈で，これより概ね 4 分枝して蝙牛豰 
に向から固有蝸牛豰動脈の各枝, 前庭, 三半規管に向か 5 前㤛動眽の备枝となつて夫そ备部に固有の毛細管網を

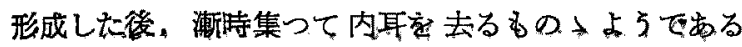
と・所が氐の中耳（主をして鼓宝）を灌流する動脈は大

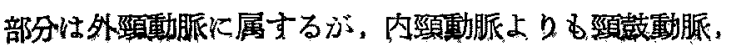
梁小岩様動脈を受けていると。

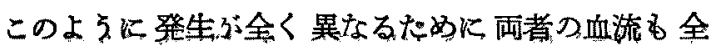
く異なる・しかし著者の得た慢性症の所見では勿論，

Young によれば正常者に叔いる淋巴の交流はあるる の১ようです, 即ち著者の得た広義の骨小管内の体液

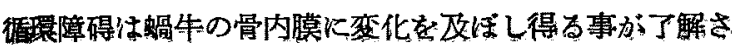
れる.

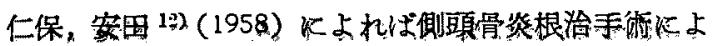

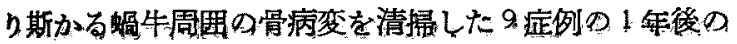
聴力増進の平均は，図８の如くせある。

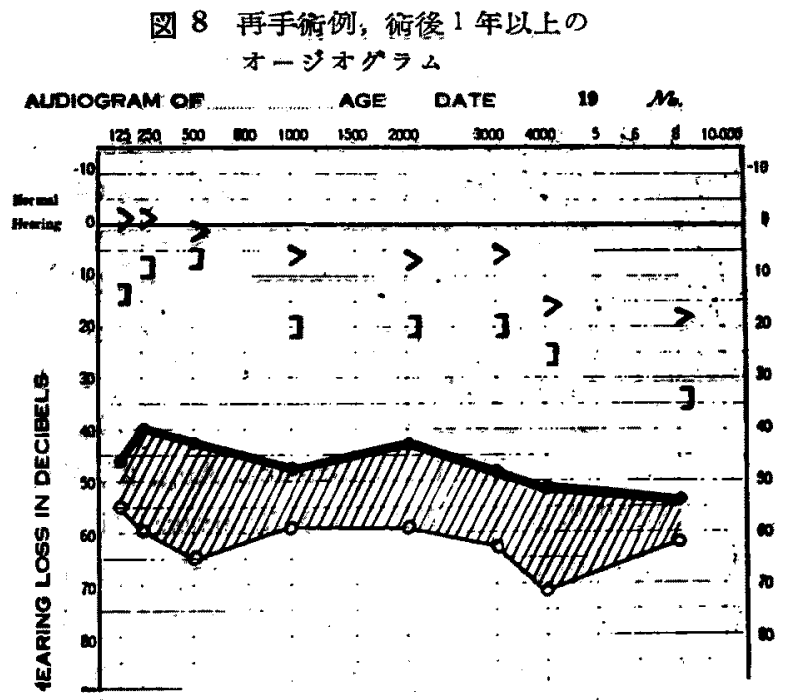

\section{再手術例９例平均}

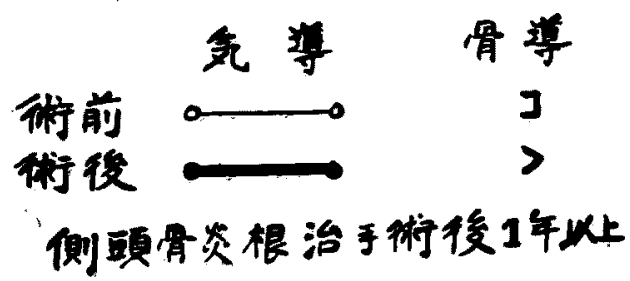

即ち所謂中耳根治手術て蝸牛豰を取り国七骨病变の存，

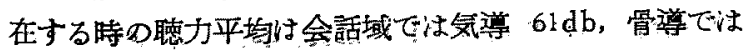
$15 \mathrm{db}$ で，側頭骨炎根治手術挠の平均は氛導 $45 \mathrm{db}$ ，骨尊

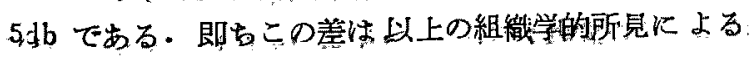
ஆ市索.
しかし従来考えられた卵用空，画中空上りの内耳炎の

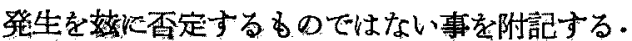

(7) 职小骨：第3例比いて検索したので概要を述

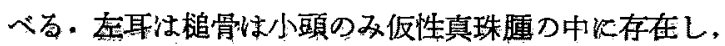
砧骨は不明，鐙骨む消失していた・棺骨小頍は骨病变は 極めて高度で，一言にして述べれば Osteoporose を呈 し，骨は殆ど死骨化している。

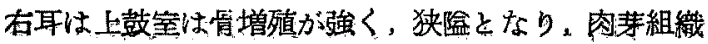
に埋められており，槌骨，砧骨は周囲と骨性㵠着して 全然動かなかつた・組織学的には椎䉰, 砧骨共に心言に

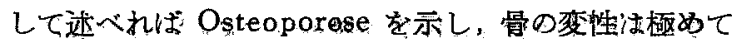
高㡲でる。

斯かる所首は Myringoplasty，Tympanop lasty， Myringostapediopexie 等の際纯極みて重要な事で ある。

\section{第4 章 結 語}

（1）７例の慢性側頭骨炎による高度難㥁者の臨床的 亚び組織学的祫索を行った。

（2）鼓膜郡胃，鼓空阶見は化学抗生物質の発達した 今日では，急性あるい性急性增悪所見飞运しく，病気 の実態である組織学的所見に比して余りにす軽微に過 ぎる。

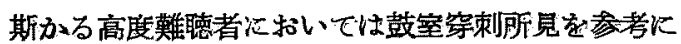
し，レ線所見重要視すべき事を提唱する。

（3）乳奻児期の正確な検查の不可能な時期の訩断が 最す夫切ですり，ストマイ難聴の診断は軽卒に下して はならない。

（4）レ楾所完では全例火変化を認めた。その撮影法 は Stenvers 法, あるい性々の変法がよい.その際の 判定に特いても Masking effect なる言葉は鼓膜所 見，一般症状はよくなったが，組織学的には未だ治嵡 してない事を意味しているからこれれ迷わされては ならない.

Pneumatisations-Hemmung $\{$ 先天的の場合。 るが，慢性骨炎管䯣炎のために含気蜂巢が発育できな い場合が多く，又乳様突起自身も正常の発育がでをな い場合があるから注意す心゙きで市る。

(5)手術々式：乳奻胃期に所謂中耳炎を，組織学的 に慢性化させない事ぶ最も大切であるから，その原因の

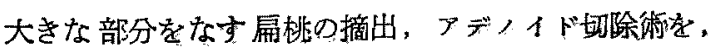
所謂中耳炎が薬剂潦法飞遷延し，鼓膜の肥厚浸潤の消失

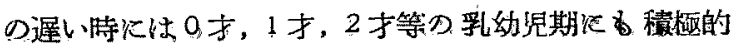

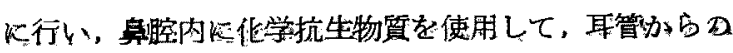


再感梁を減少させねばならない。

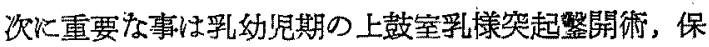
存的側嗔骨炎根治手術を早期飞行了事である・即ら生命 の传険を除く目的であれば遅くてもよいが，機能即ち聴 力改善を目的とする咟合は可及的早期がよい，化学抗生 物望の進歩により恰む乳様突起炎が娍少，あるいは殆ど 消失したかの錯覚が耳鼻科医を支配しているが，組織学 的の慢性乳様突起炎は琶らくは減少していないである 了.

側頭骨の全病霆を除去し, 蝸牛豰を骨病变の重仕から 救うためには側頭骨炎根治手街が最もよい，しかし幼児 では伝音系除去の聴力に対する害と，螖牛殸を取り团む 骨病变の害との比較が極めて困難なため保存的側頚骨 炎根治手術で待機している症例が半数䎲ある。

三半規管の内耳渡孔，慢性限局性内耳炎は積極的谁手 術により除去すべきである・これたより聴力の改善を見 る場合が多い.

（6）組織学的所見：乳幼胃期に和いては慢性含気䗋 巢炎，骨炎骨髄炎であるが，長年月経過したものは慢性 骨炎，骨䯣炎であり，含気蜂巢炎の所見は鼓室，乳様洞 の附近に見られるのみである。

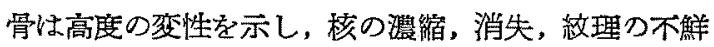
明，異常敘理の出現，多孔質化，線稚㥭化，脆弱化， Osteoporose - 等の極めて高度の变化を示し，軟部組織

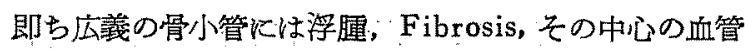
を圧迫等の体䍇循環障碍を示す。骨小管，骨破壊腔には 脂肪䯣が現れる。

全体としては寧ろ修復のための急性炎症所見に乏し く，骨新生，吸収所完に乏しく，真癒るでるなく，癒 らねでもなく，次第に商度難徳となつてしまつた所見で 西る。

(7) 内耳と骨病変：前述の骨小管，骨破壊控は膜様 迷路之連絡する場合肪出古。即ち斯かる体液循環障碍は 三半規管に悪影響を友ぼす。螖牛設にも悪影響を及ぼす であろう。

斯かる内耳に隣接する骨病変を除去すれば，内耳の残 存機能は出る程度改善される。

(8) 耳小骨に組織学的に Osteoporose が証明され た.この所見は Myringoplasty. Tymparioplasty, Myringostapediopexie 火際し重要である。

$$
\text { 文献 }
$$

1) Eggston and Wolff: Histopathology of the E. N.T; 1947. 2) Scheibe: Aetiologie u. Pathologie des Empyems im Verlaufe der Mittelohreiterung; Zeitschr. f.o. Bd. 48, S. 1, 1904.

3) Neumann: Zur Pathologie und Klinik der akuten Mastoiditis; Zeitschr. f. H.N.O. Bd. 20, S. 155, 1928. 4) Lange: Die Pathologische Anatomie der Mastoiditis; Zeitschr. f. H.N.O. Bd. 20, S. 1, 1928.

5) Krainz: (i) Ueber die Auskleidung der lufthaltigen Warzenzellen Usw; Zeitschr. f. H.N.O. Bd. 8; S. 46, 1924. (ii) Untersuchungen über die Mastoiditis; Zeitschr. f. H.N.O. Bd.13, S. $361,1926$. 6) EckertMöbius: Mikroskopische Untersuchungstechnik und Histologie des Gehörorgans; Denker-Kahler's Handbuch, Bd. 6, S. 211, 1926. 7) Tobeck: (i) Pathologie und Klinik der Pyramidenzelleneiter. ungen; 1939. (ii) Anatomische Untersuchungen über die Pneumatisation und die Wegleitung $z u$ Spitze; Zeitschr. f. H.N.O. Bd. 37, S. 152, 1935. 8) Mayer: Pyramidenzelleneiterungan; Zeitschr. f. H.N.O. Bd. 42, S. 1, 1937. 9) Richter: (i) Beitrage zur Pathologischen Anatomie des Ohres; I IV Archiv. f.O. Bd. 139 142, 1935 1937. (ii) Die ent $z$ ündlichen Erkrankungen des Mittelohres; 1953. (iii) Die Verhülung lebensgefährlichen otitischer Komplikationen; H.N.O. Heft. 4, 1954. 10) M. Wharton, Young: Mercury as a Casting and a Contrast Medium; Science. Aug. 22, Vol. 116, No.3008, p.207, 1952, 11) Kelemen: (i) Osteomyelitis of the Temporal Bone; Otolaryngology. Vol. 11, Chapt. 20, p. 1, 1955, 1957. (ii) Collateral Infection of the Temporal Bone in Fulminating Osteomyelitis of the Frontal; Laryngoscope. 54, 76, p. 1, Feb. 1944. 12) S. Niho, M. Niho, Furuya, Yasuda and Kudo: Radical Surgery on the Temporal Bone and Labyrinth Operation for Hearing Improvement; A,M.A. Arch of Otolaryngol. Vol. 67, p. 156, Feb. 1958. 13) S. Niho, M. Niho, Yoshio, Iwatake, Takahata: Petrositis and Osteom. yelitis Temporalis; Yokohama Medical Bull. Vol. 5, No. 2, p. 125, 1954. 14) 二階堂：急性利嘫突起

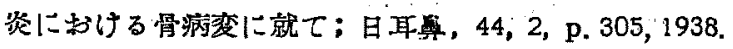
15）小田 (醇)：耳性化朖性軟媨膜炎にわりる錐体尖の

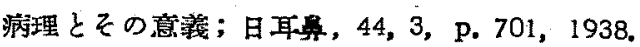
高原 (高)：（i）錐体尖炎；日耳全書， 1, 3, p. 129, 


\section{安田論 交附図（I）}

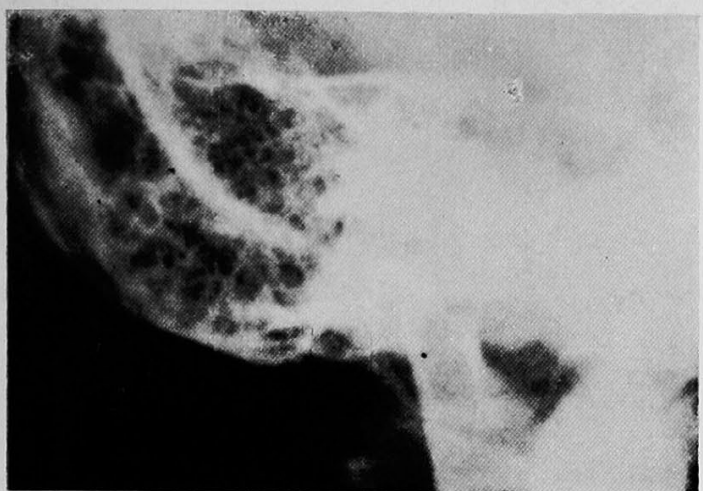

附図 1 Stenvers レ線像健康冽 対照

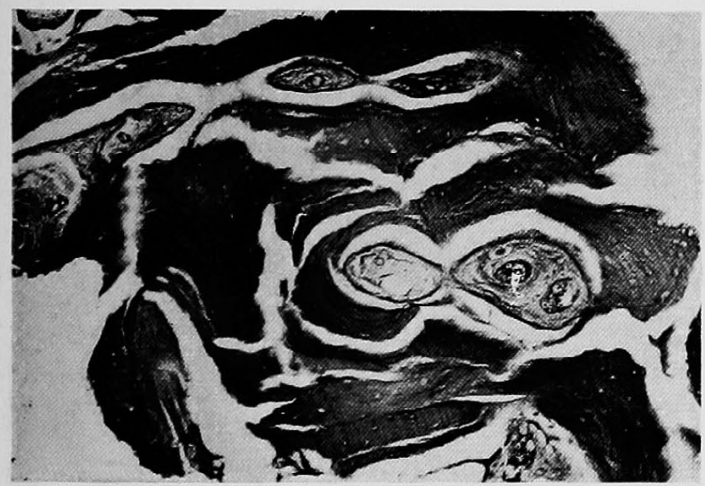

附図 3 第 1 例 左 外丰道上梀 $(\times 100)$

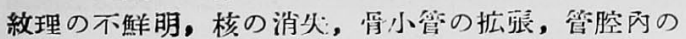
Fibrosis, 結合織.

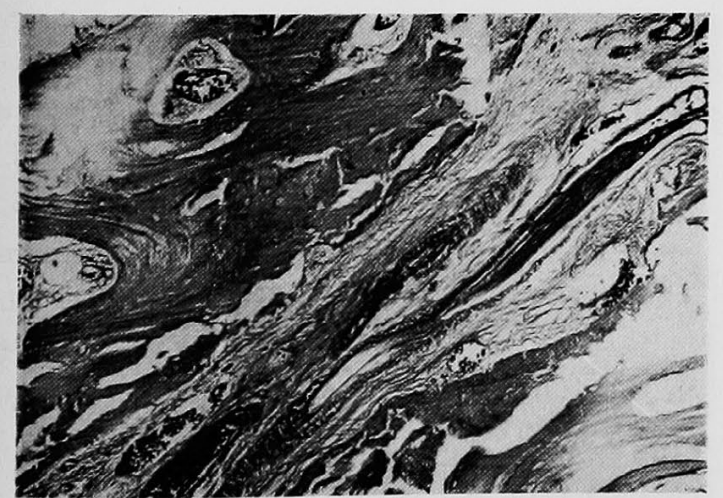

附图 5 第 1 冽 庄隅解䗋穼

斜めに走る小含気腔及び周囲㳄部租織の蔽浪化.

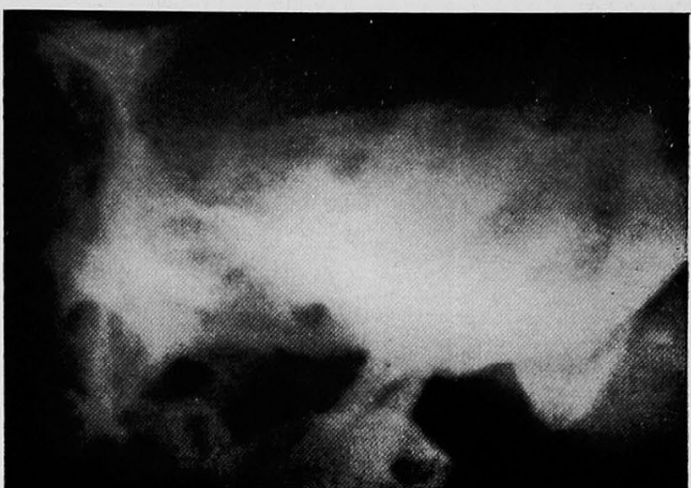

附図 2 第 1 例 左耳:

督髄炎様・典型的な危険性測西县の像・

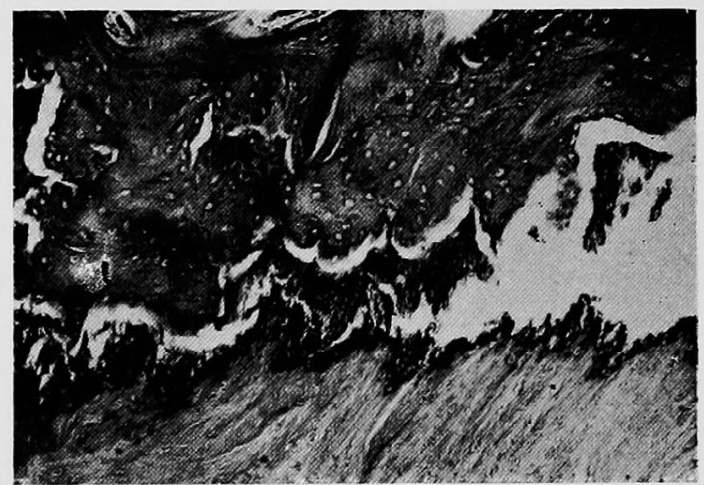

附図 4 第 1 例 左 乳様乲起尖端

上牛部の霄の核の消失，紋理の不鲜明。中央部にへ

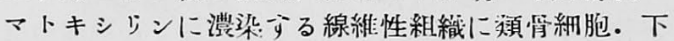
牛部は軟部組織・

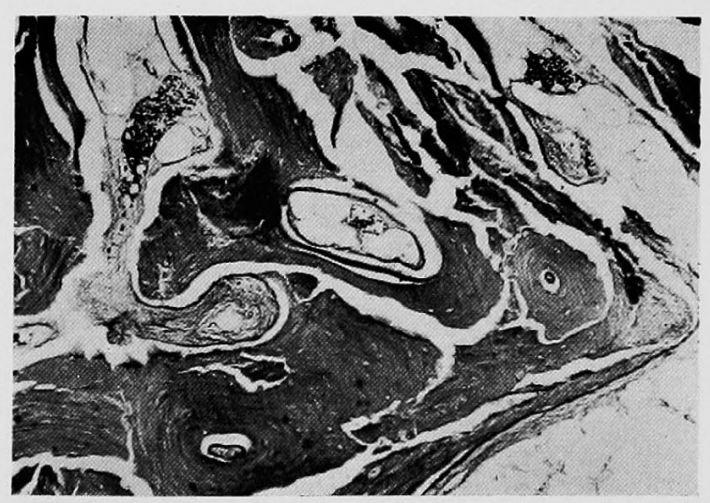

阶図 6 第 1 例 左 闑閾蜂窠

変性の柕い骨の右方に八管を中心とする時代の新し

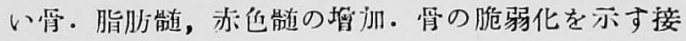
合貝の踓断. 


\section{安田論文附図（II）}

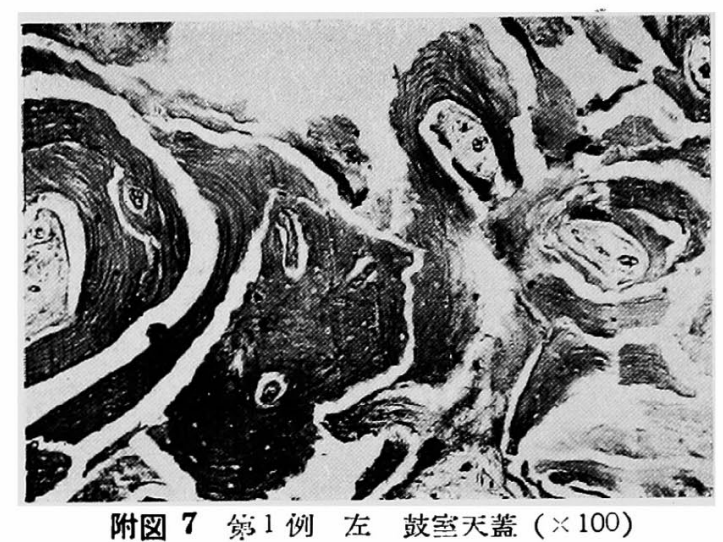

骨小管腔の Fibrosis。骨の胣弱化を示す接合犋の部 分での骨の離断。

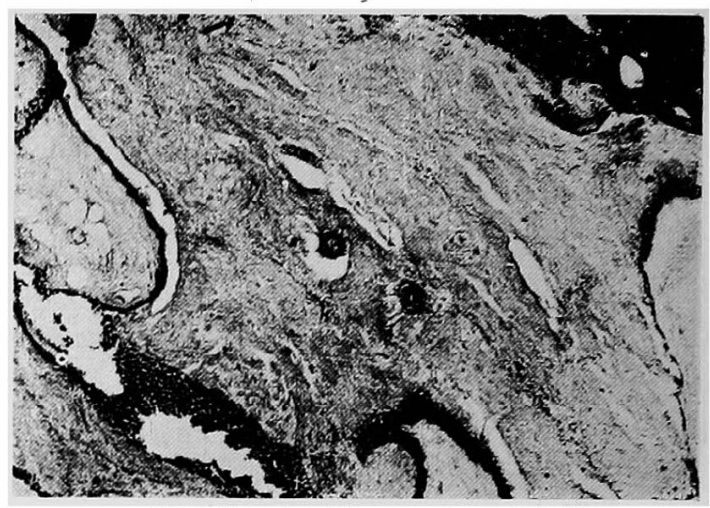

附图 8 第 1 例 左 外汇償後壁

管の脫灰・骨內膜がへマトキションに濃染.

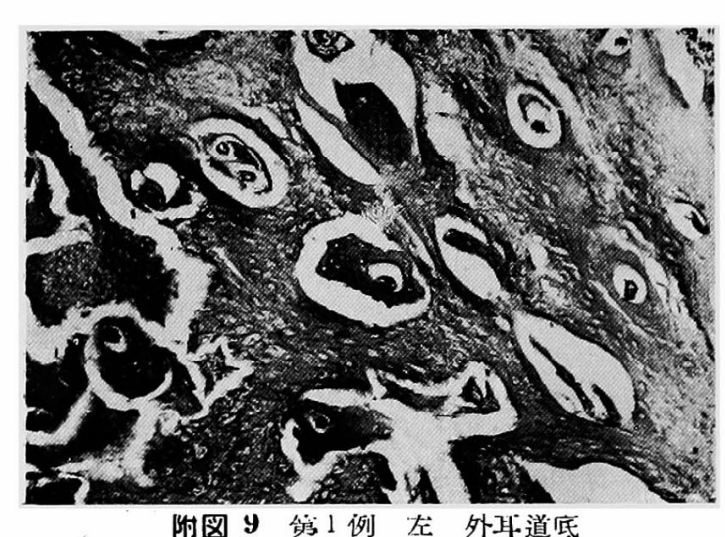

八管を中心とする比較的新しい霜及げるの周囲の管 の多孔貿伦.

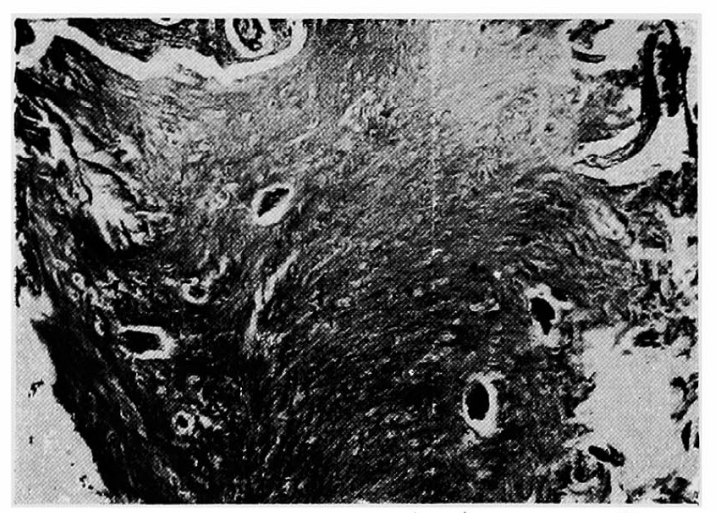

附図 11 策 1 例 左 叿管外例筒壁 筒の線維样化。

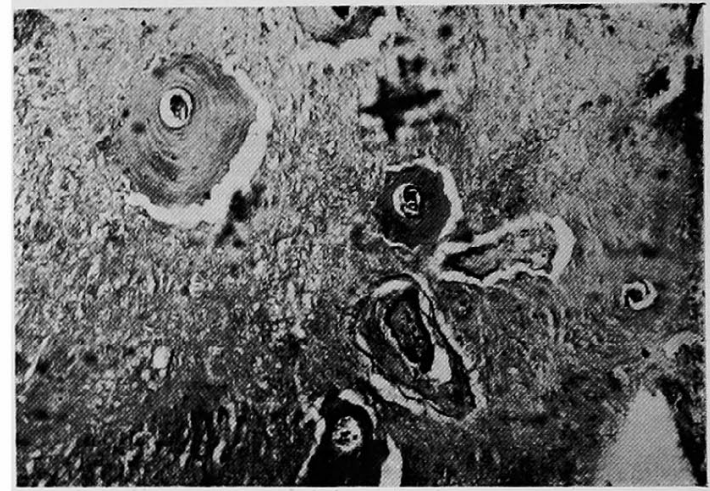

附图 10 菂1 冽在 外-4道前壁

留の多孔筫化一部楾維样化，八管を中心と方る時代 の新しい霄及びこの吉い骨との間の朔断.

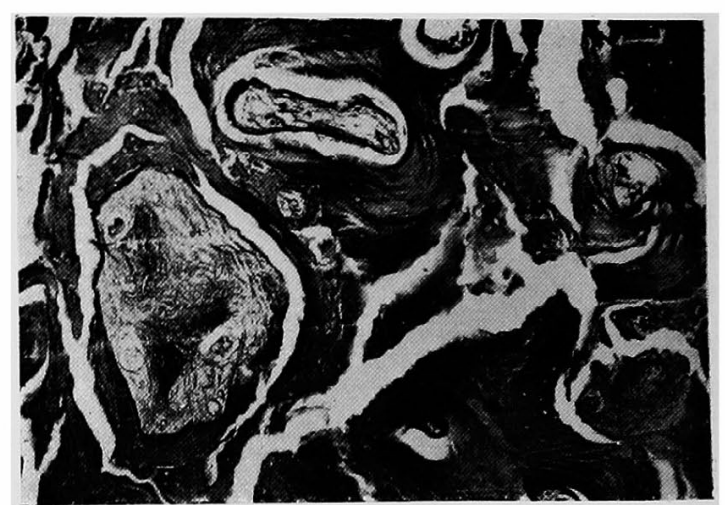

附图 12 䇣1 例 左 釗体尖（仁保・本野法） 筲の䜅断. 霄小管內の Fibrosis, 骨队脱の濃染・ 
安田論文附図（III)

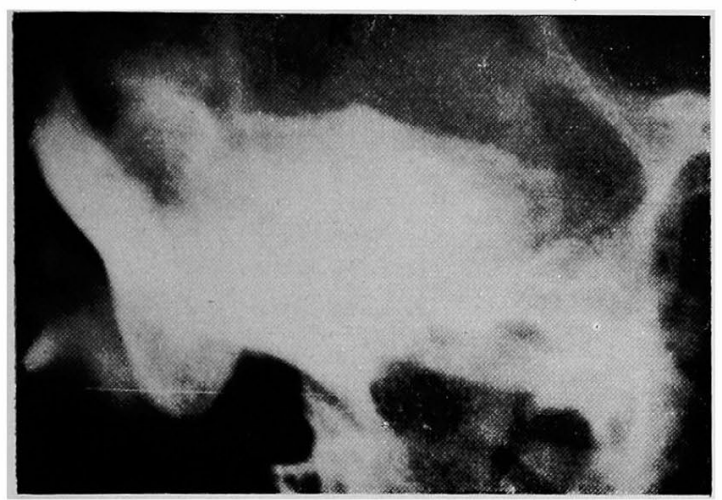

附図 13 第 1 冽 右耳. 管㩆焱様・危険性側頭骨の像

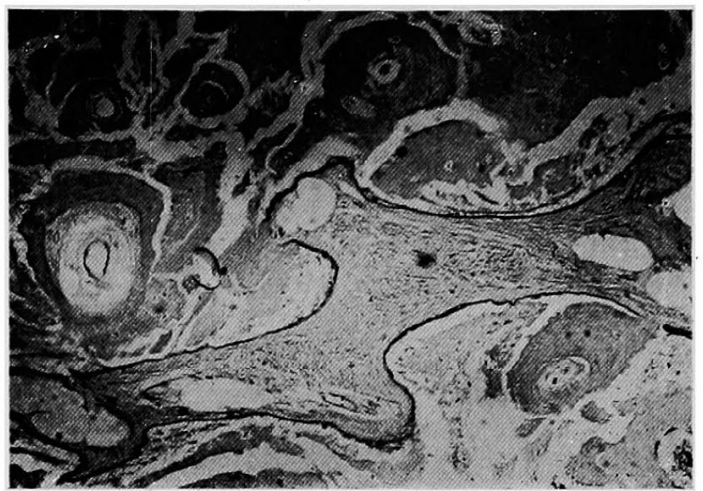

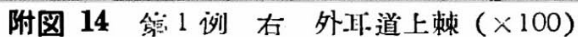

霄の脆弱化著明。八管，霄小管を出心とした時代の新

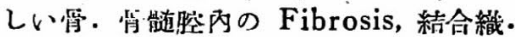

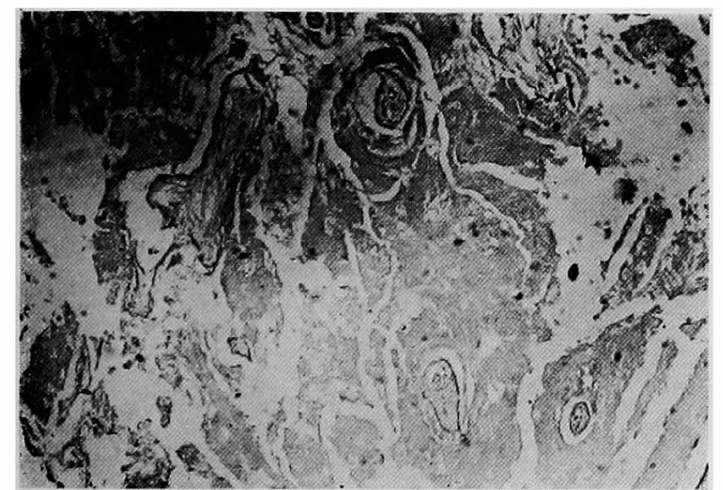

附图 15 第 1 泡 右 乳榚润の外側壁 骨の多孔筫化。骨內朕の濃染。

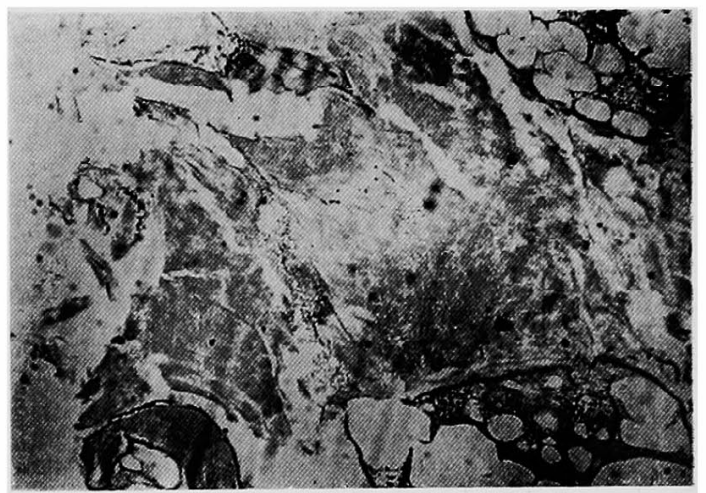

附图 16 管1 例 右 乳様乫起尖端

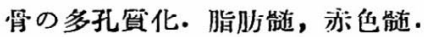

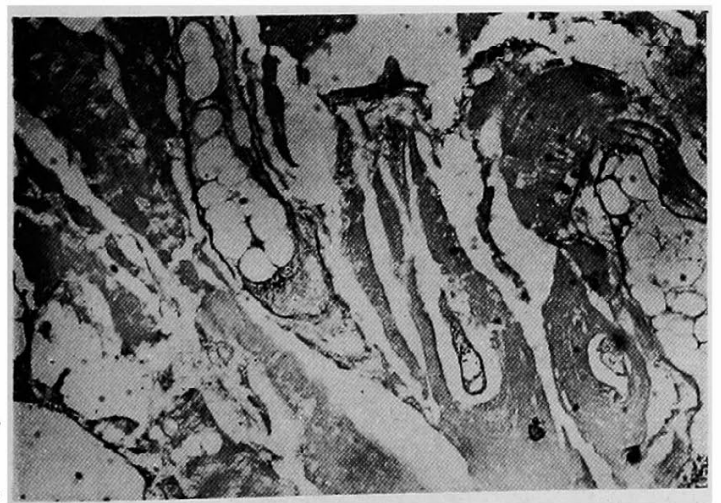

附图 17 第 1 例 右 $\mathrm{S}$ 状润壁

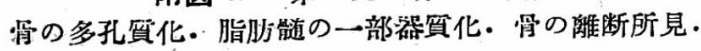

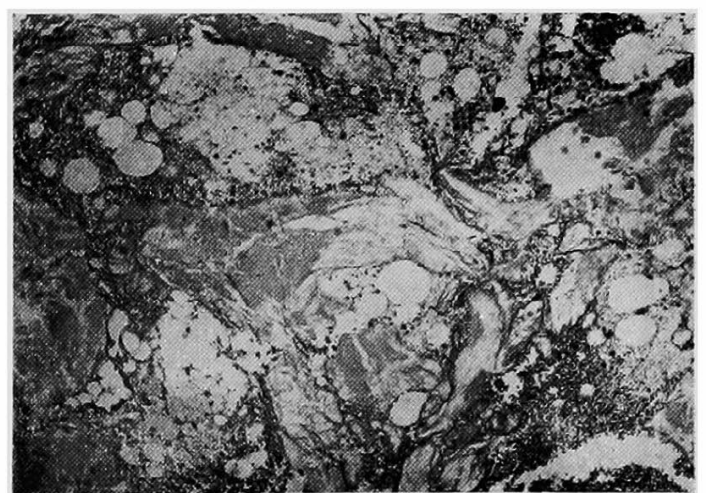

附図 18 第1 例 右 後頭顆

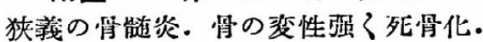


安田論 交附図（IV)

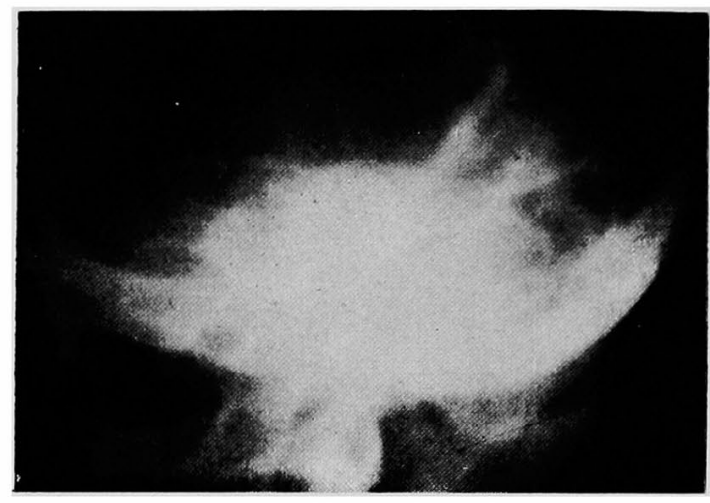

附图 19 第2 例左-耳.

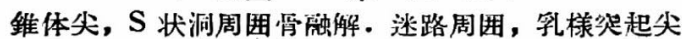
端不鮮明. 三牛規管部不鮮明化. 危険性测頭督の 像.

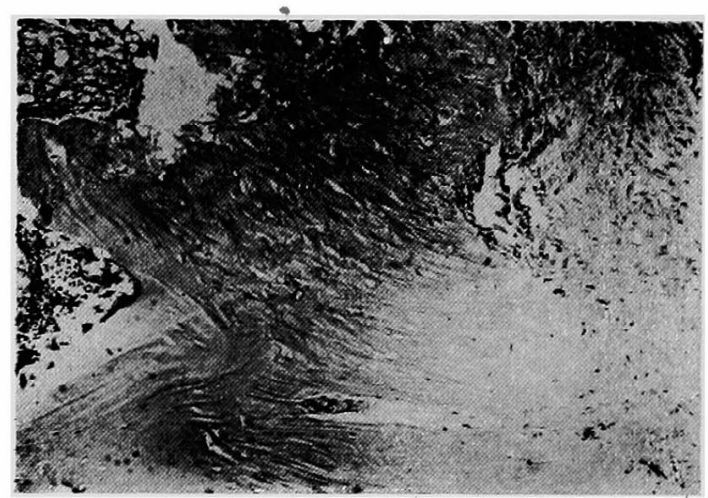

附図 21 第2 例左 乳様突起尖端

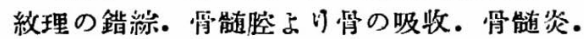

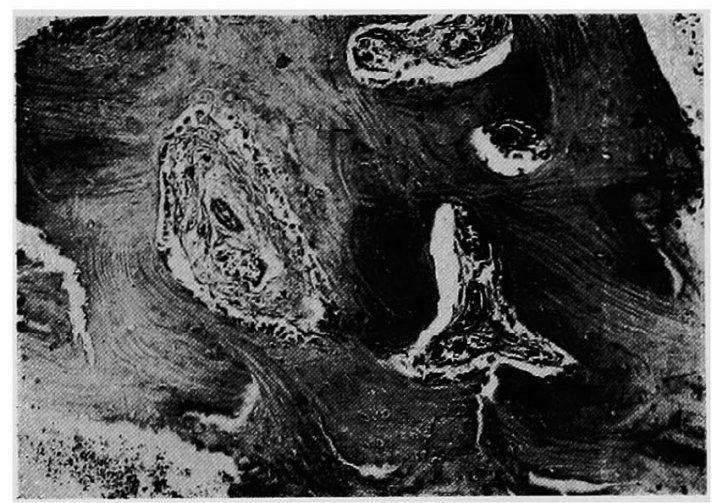

附図 23 第2 例左上牛規管附近 異常紋理の 出現. 骨小管腔內の Fibrosis, 結合 綫，周辺に造骨紏胞の並列.

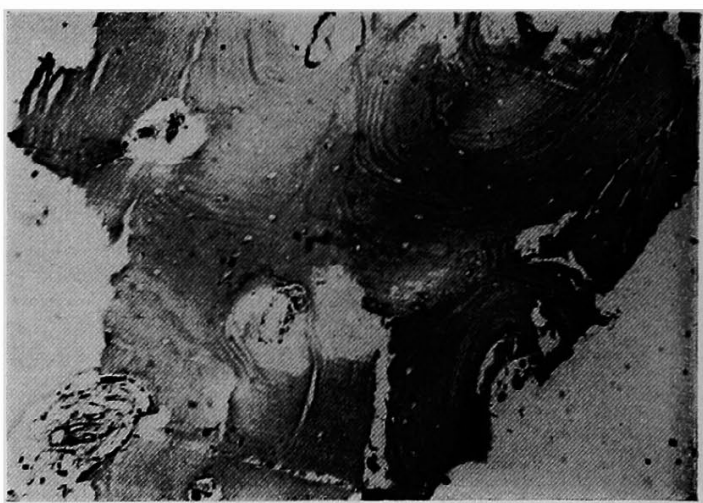

附図 20 第 2 例 左 乳様润の外例壁 $(\times 100)$ 核の.消头乃至さ濃縮. 界常紋理の出垷. 督の吸收 像.

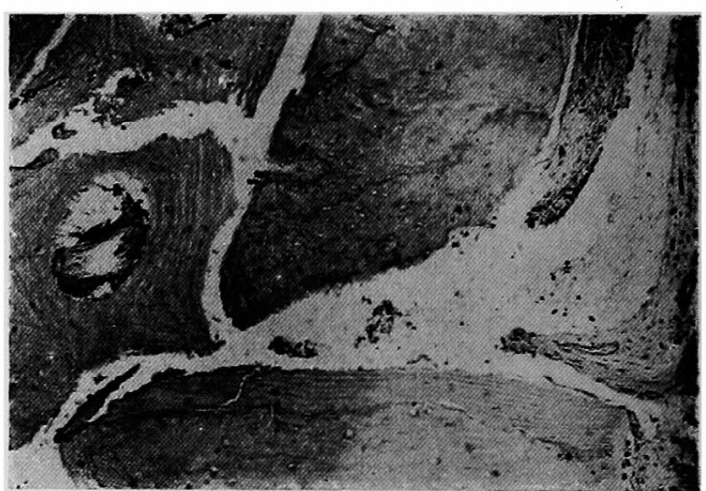

附图 22 第2 例 左 闌闌蜂窠

紋理の不鮮明. 核の消火多乙. 鋸菡状の接合線の多数 の走行. 响状吸收. 右方に闪芽組織.

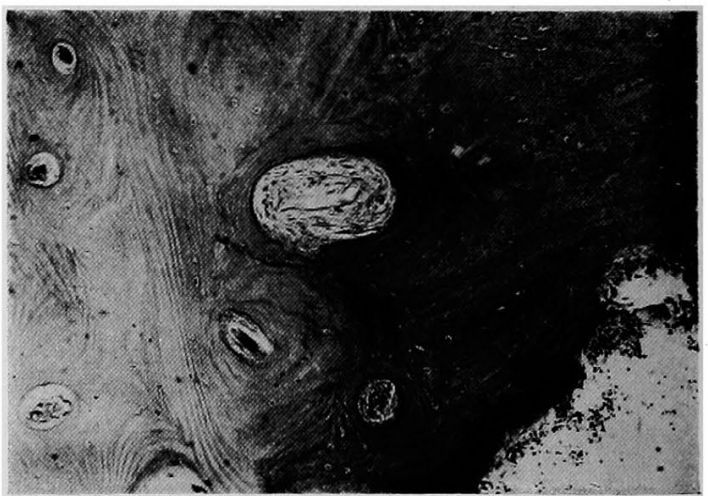

附图 24 第 2 例 左 錐体尖（仁保・平野法） 紋理の錯綜，八管，骨小管腔の骨新生による縮小且つ 再び窝状吸收. 管腔內の Fibrosis. 


\section{安田諭文附図 ( V )}

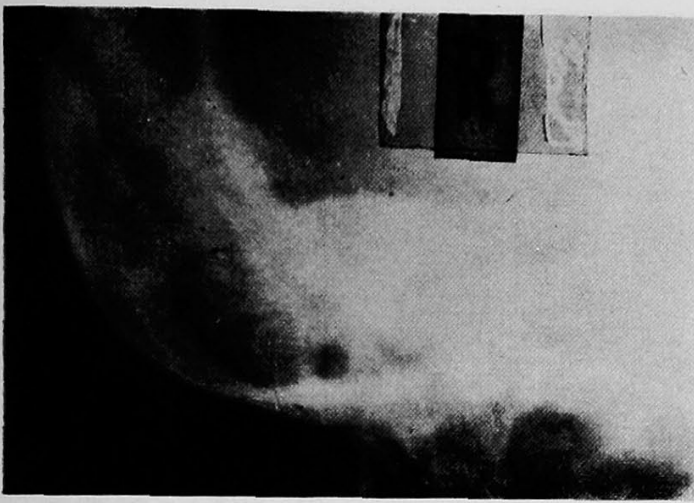

附图 25 第 2 冽 右耳:

不鮮明.危俛性倒頭骨の像.

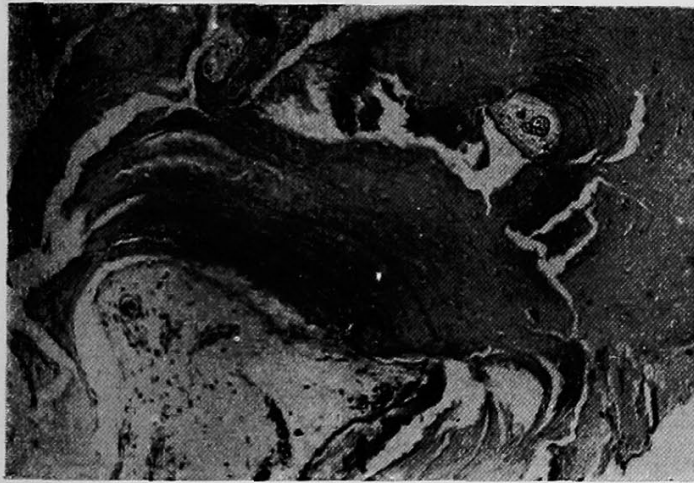

附図 27 第 2 例 右 乳様洞

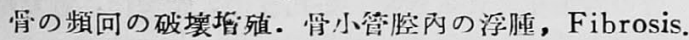

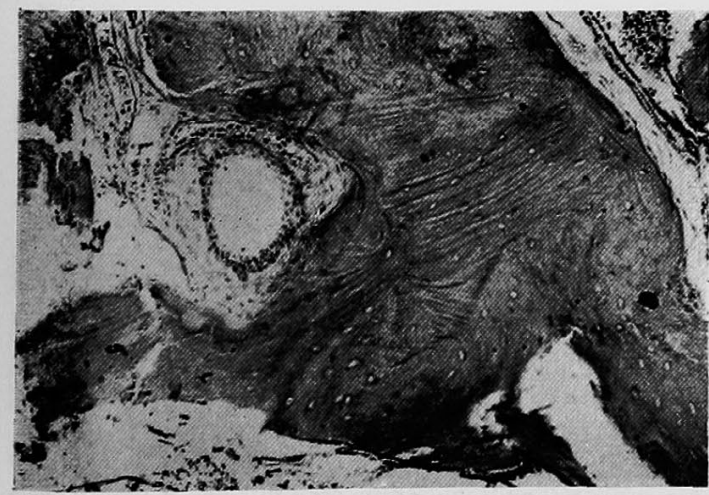

附图 29 第 2 例 右 後蜂穼列 (山下法)

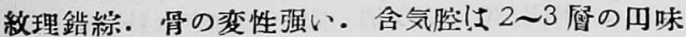
を橆びた上皮細胞に囲まれた小腔，周辺に類骨租 織.

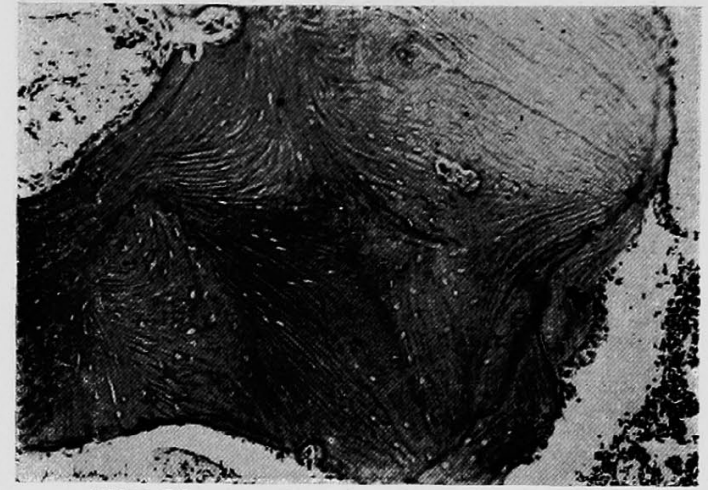

附图.26 第 2 例 右 乳栐润の外側壁 紋理の錯綜．買常紋理の出現．㗬状吸收．

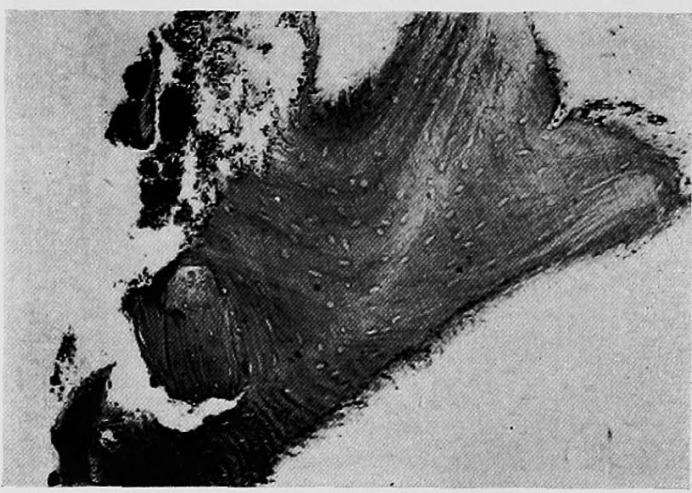

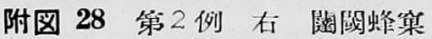
骨小腔の桩大，核の消火．紋理不鲜明.

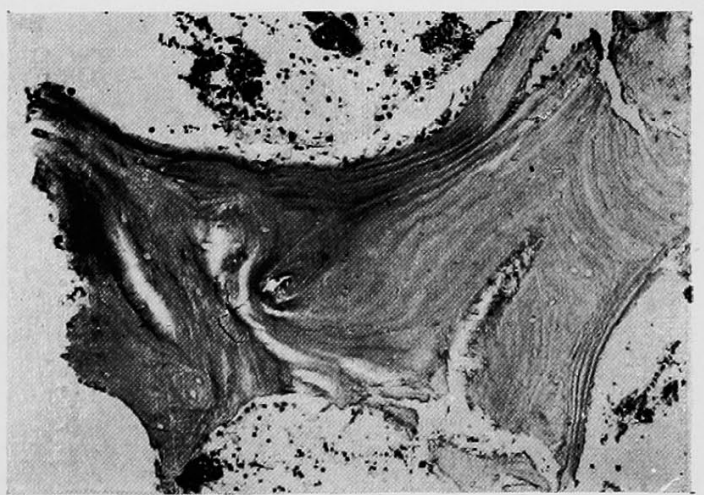

附图 30 第 2 冽 右 後下惵穼列 (Kramm 法)

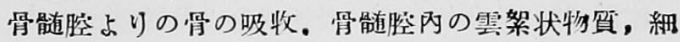
胞浸泪. 


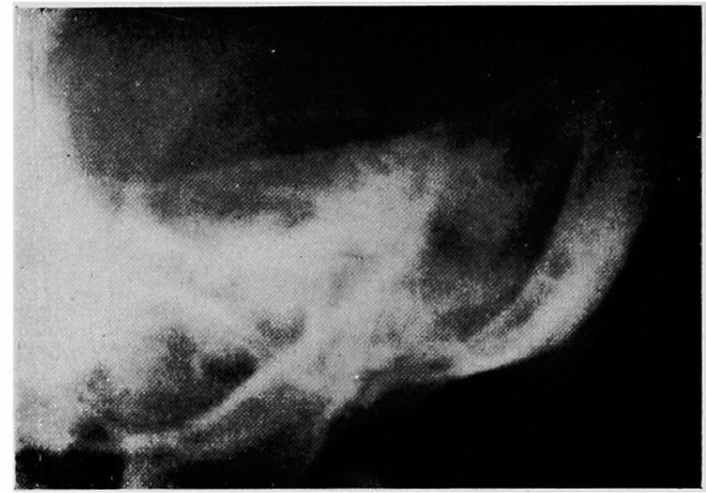

附図 31 第3 冽 左上F

不鲜明. 水平, 後牛裀管不鲜明.

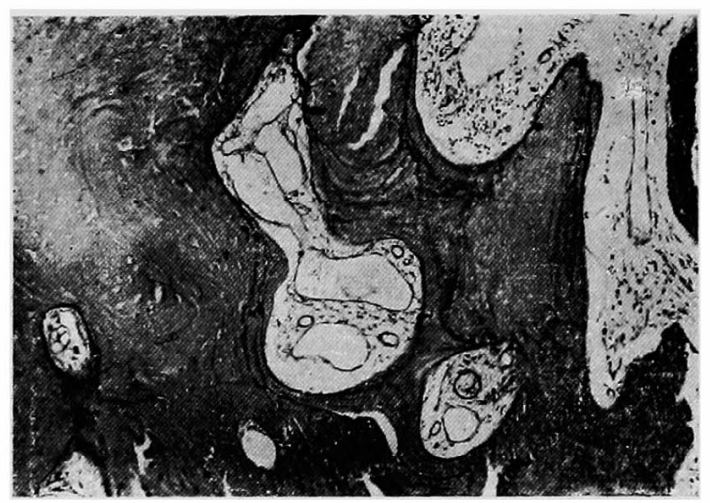

附图 33 简了例左隅角蛒窠

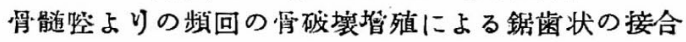
線が多数・管腔可の浮胛, 空虚な血管腔, 拡張した 淋巴管.

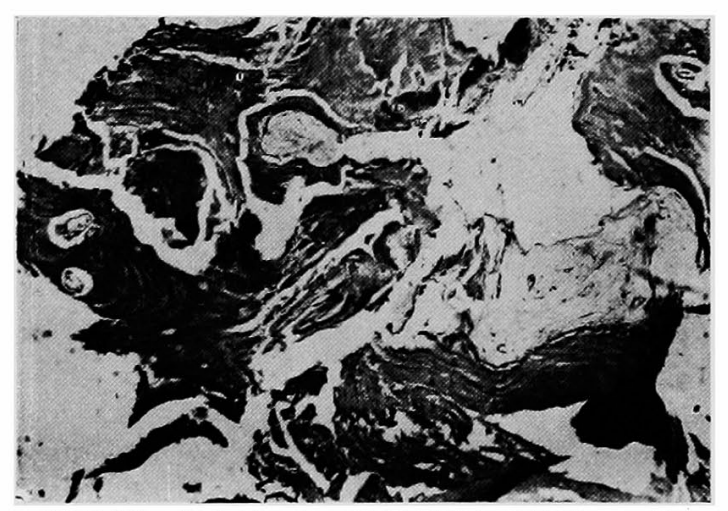

附图 35 第3 例左骨性迷路より堆殖せる筒

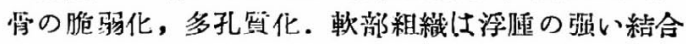
緎.

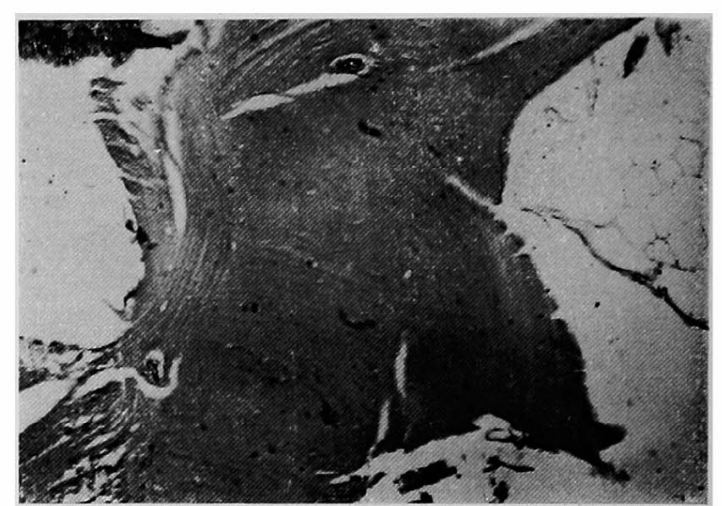

附図 32 第3 例 左 乳様栄起尖端 核の消失, 紋理の不鮮明. 脂肪髄.

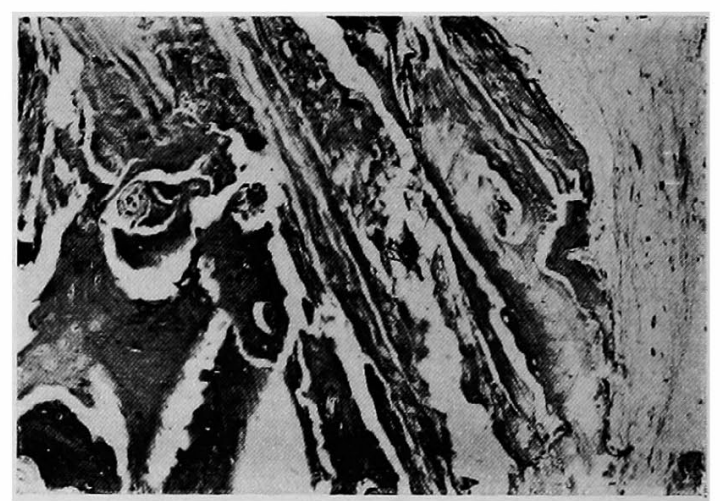

附図 34 第3 例左 乳椂洞

骨の脆弱化による離断, 多孔質化, 院灰化. 右少の 軟部組織より督吸收, 軟部の浮軞, Fibrosis.

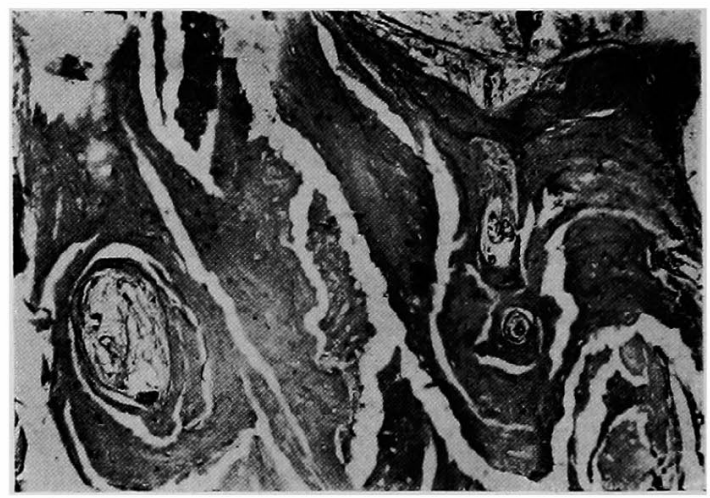

附図 36 第3 恻 左上鼓宝の外例

骨の脆弱化，離断螕にへマトキシリンに呩染する接 合線. 八然腔, 骨小管腔闪の Fibrosis, 結合織。 


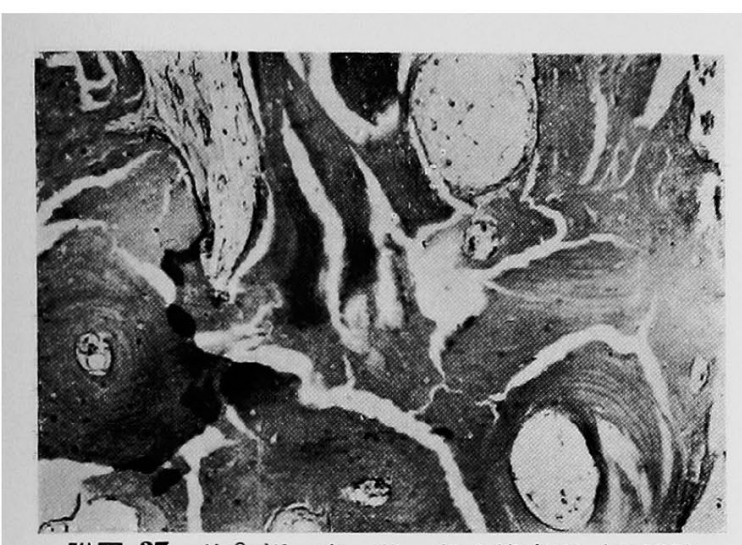

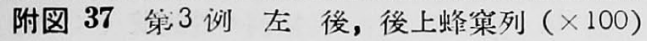
骨の脆弱化・骨小管腔內の浮䤚，結合織・右方には

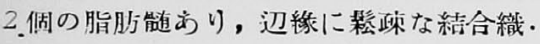

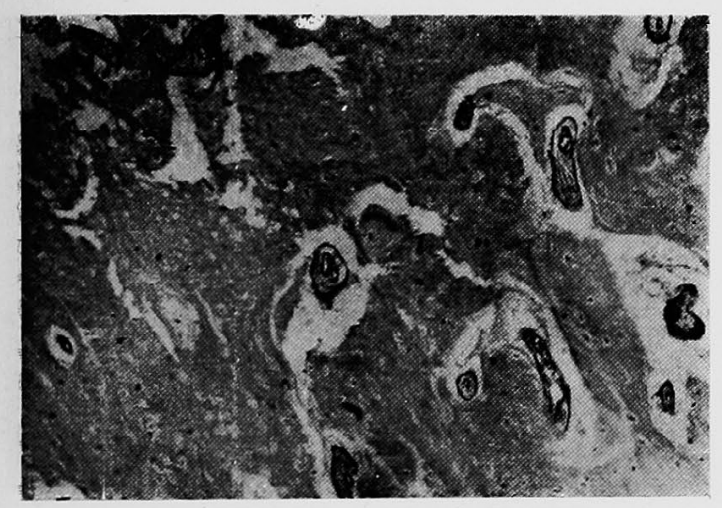

附图 39 第 3 例 左 外耳道前壁

骨の多孔澌化, 概灰・広義の骨小管丽軟部組織の收 縮，骨內膜曆のへマトキシリンに濃染.

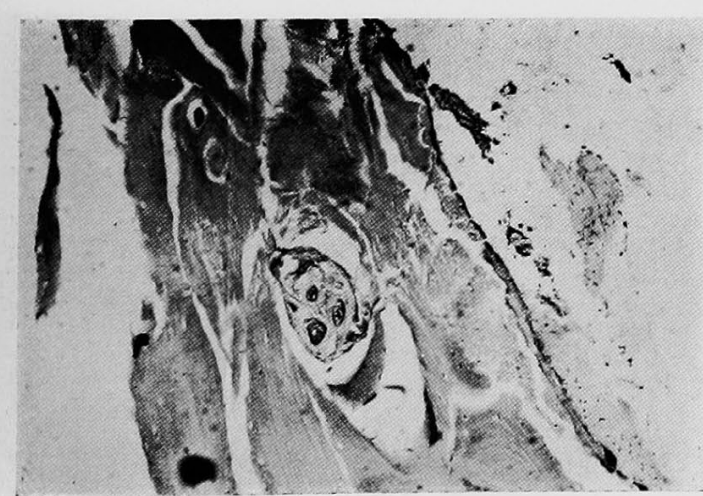

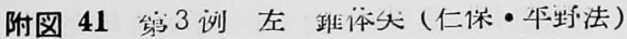
管の脆弱化，一部に脫灰化・霄小管腔の Fibrosis, 結合織・

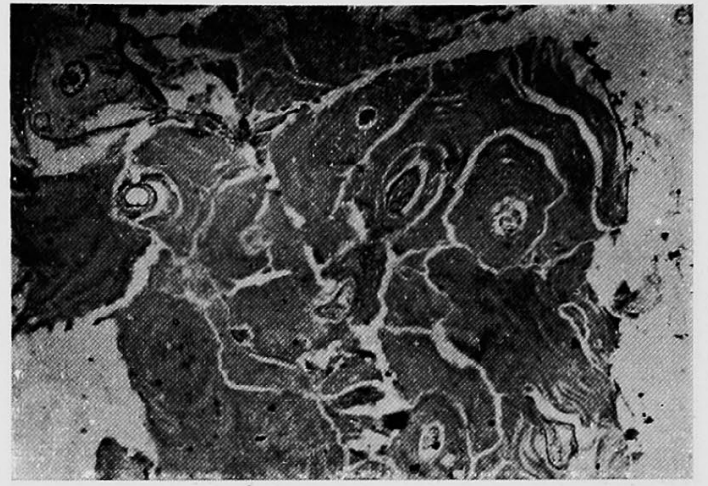

附図 38 第3 例 左 啜室天蓋

带の離断者明。八管，霄小管を山心としてばらば 5.管腔の浮膗, Fibrosis. 一部に買常紋理・

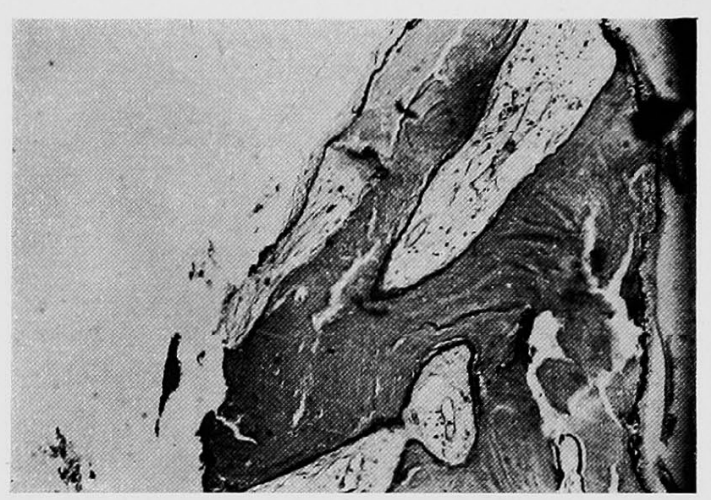

附図 40 第 3 例 左 棜筒小頭

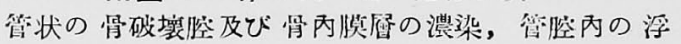

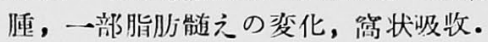

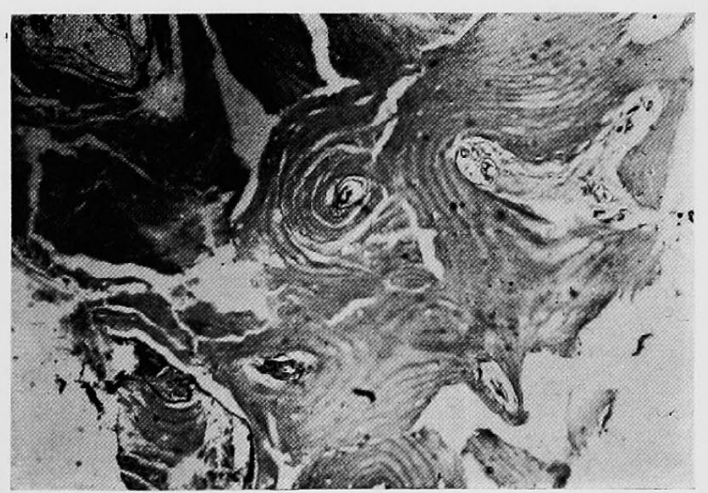

附图 42 第3 例 左 解剖学的雓体尖

霄の脆弱化, 核の偏在, 消火. 買常紋理。八管, 骨 小管腔の浮嗹・ 
安田論交附図（VIII)

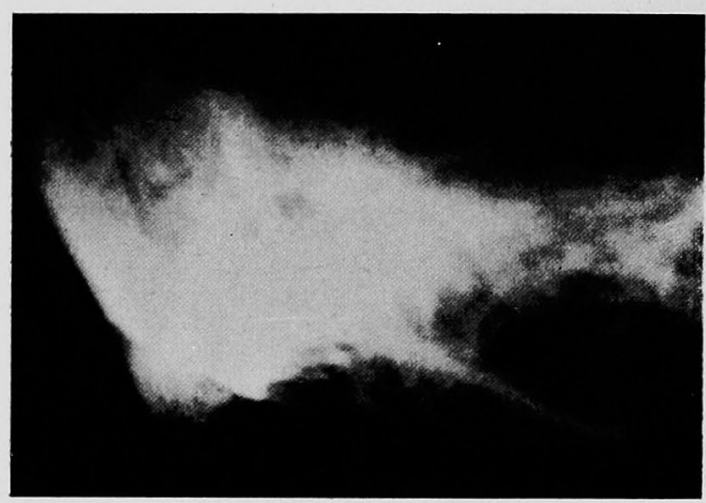

附図 43 第3 例 右开.

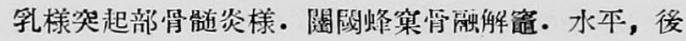
牛規管部不鮮明化.

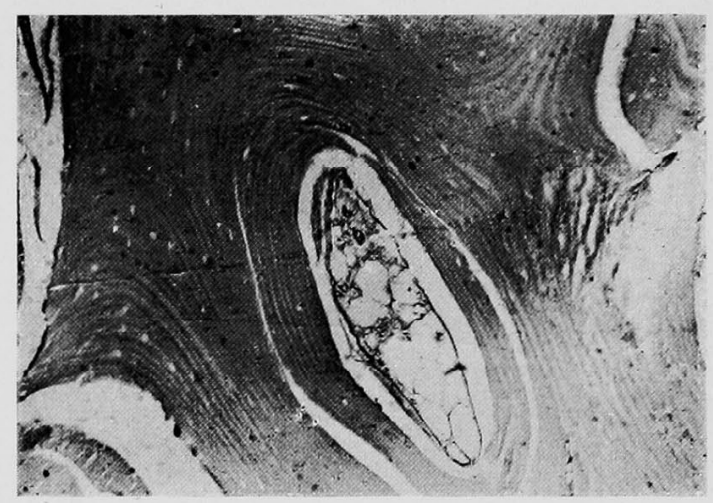

附图 45 第 3 例 有 乳様哭起尖端 骨髄腔內の営貿化.

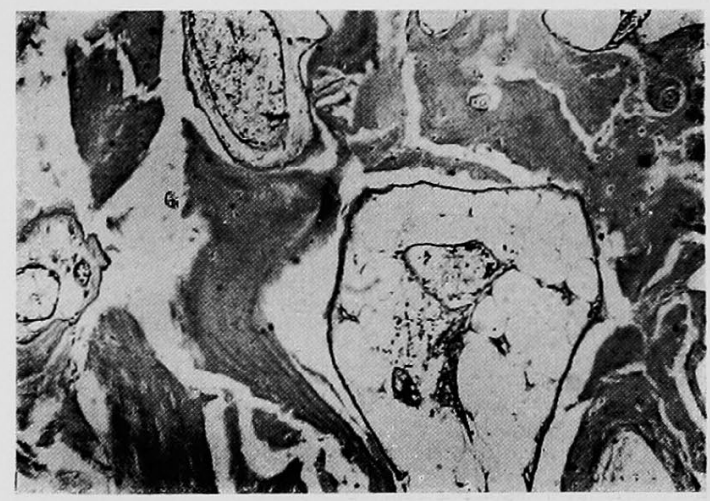

附图 47 第3 例 右砧肾

ばらばらの骨縕織, Osteoporose. 脂肪蹃。

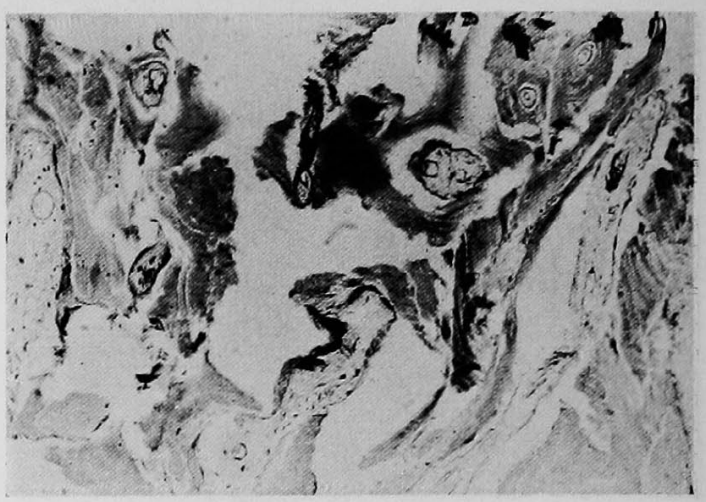

附図 44 第3 例 右 乳様洞の外側壁 $(\times 100)$ 骨の脆弱化, 变性. 一管, 骨小管腔丽の浮腫, 結合 織。

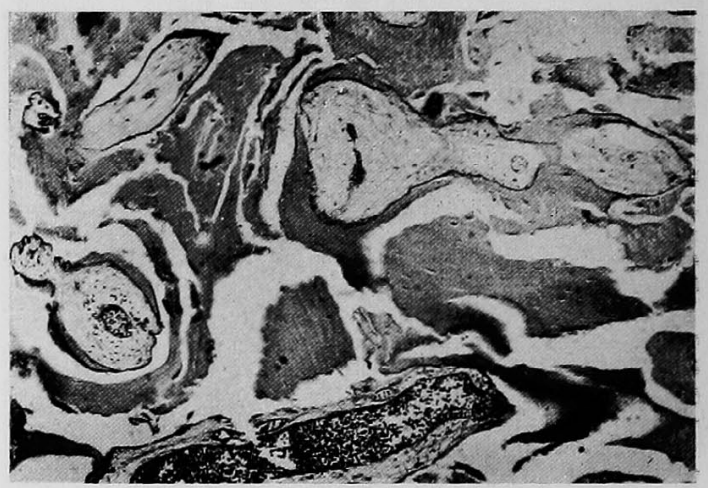

附図 46 第3 例 右 迠骨小頭

骨の脆弱化. Osteoporose. 骨小管㬵队嗂腫, Fibrosis, 軽度の細胞浸潤. 軽度の骨新生.

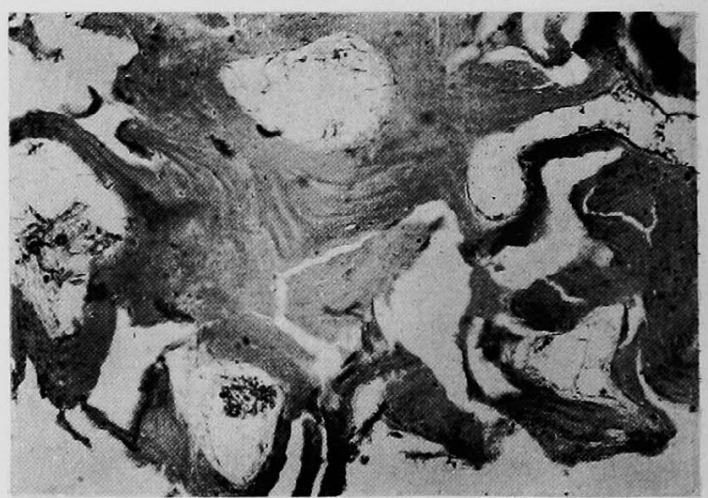

附図 48 第3 例 右 解剖学的錐体尖

骨の变性は中等:度、軟部は骨䯣腔，腔內周辺に結合 織. 


\section{安田論文附図（IX）}

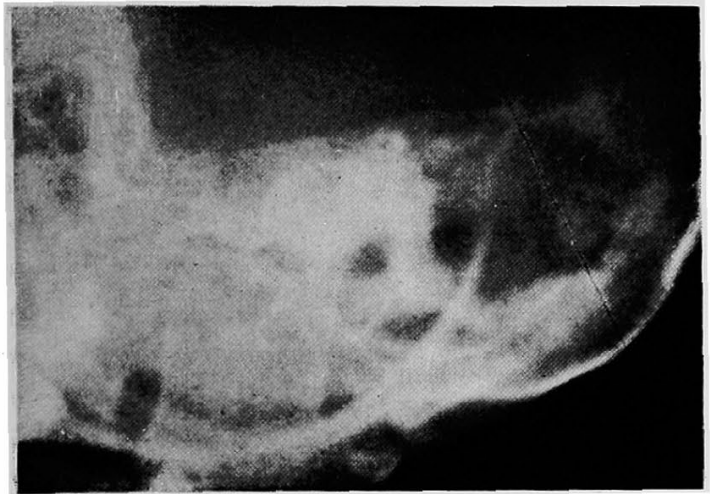

附图 49 第 4 例 左耳

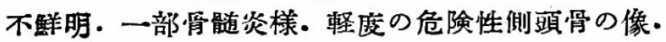

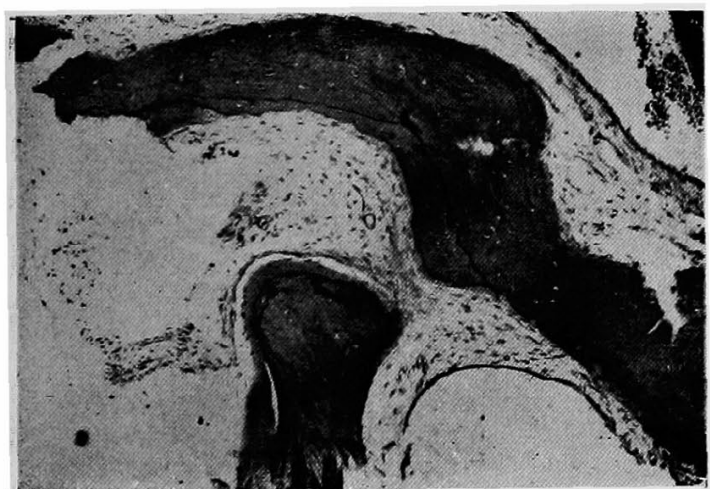

附图 51 第 4 例 左 䦚閥蜂窠

接合線を境にして新生骨の附加, 更に゙再び召状吸收

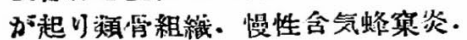

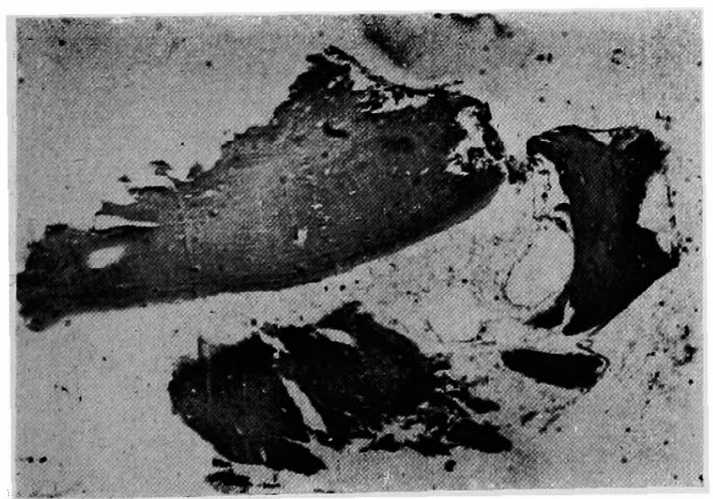

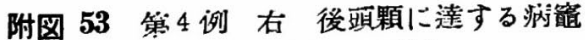
下区姑右方の骨片の死骨化・

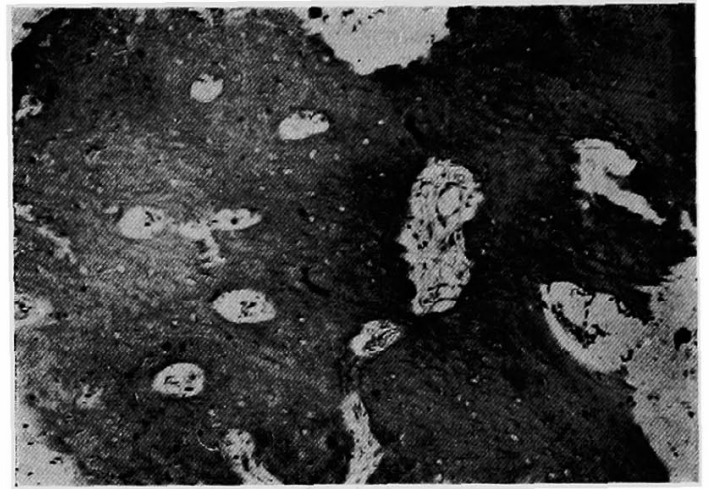

附図 50 第 4 例 在 乳様乫起尖端 $(\times 100)$

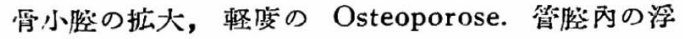
腄, Fibrosis.

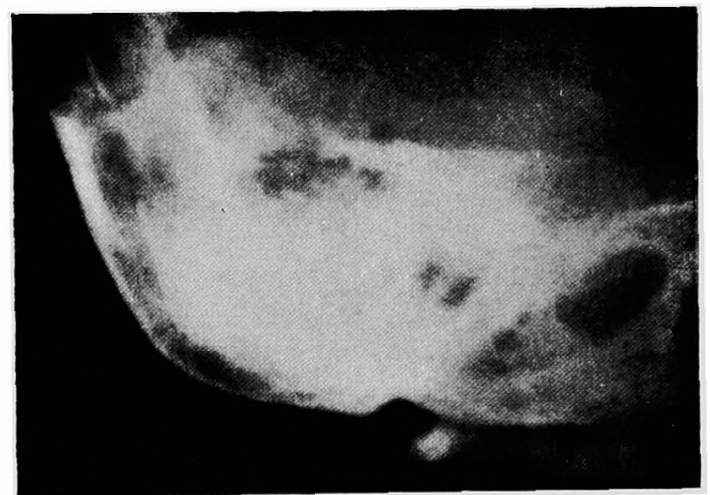

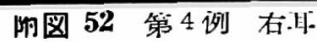
不鮮明. 一部管髄炎様.

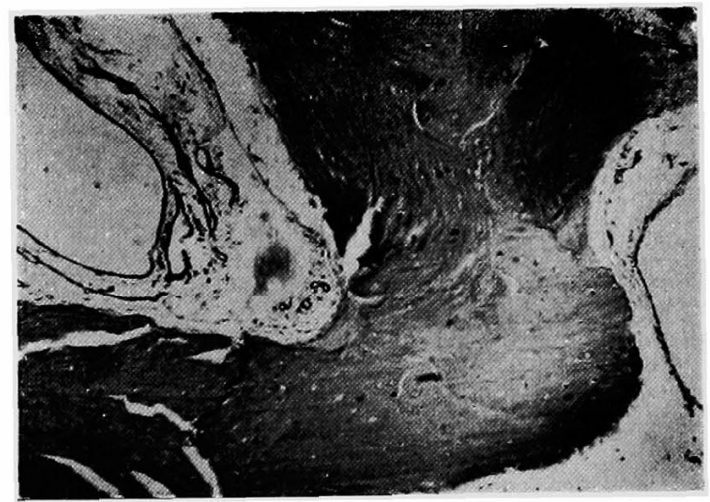

附图 54 第 4 例 右 頑骨䗋窠 慢性含気峰寨筑. 慢性骨炎. 


\section{安田論文附図 (X)}

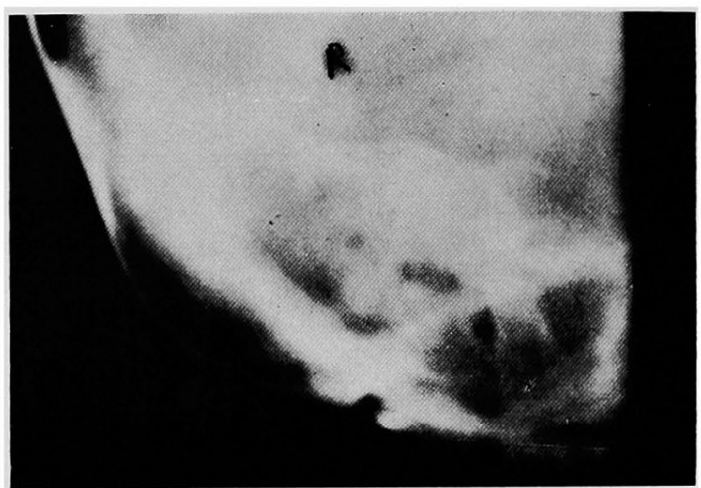

附图 55 第 5 例 右耳:

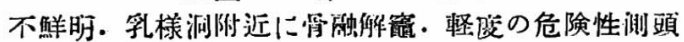
骨の像・

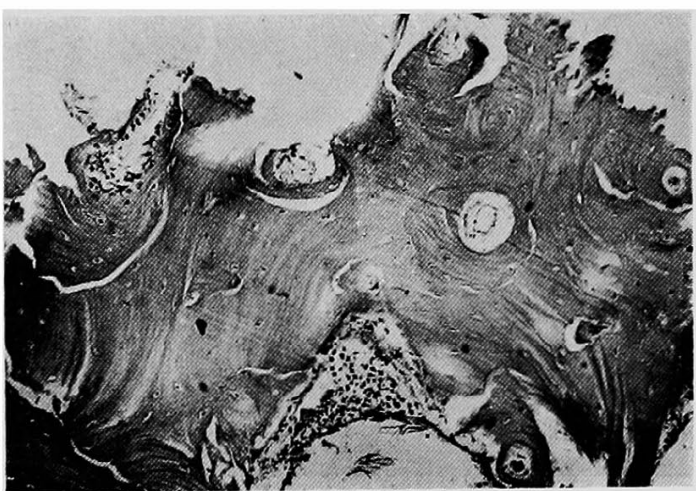

附図 57 第 5 例 右 小脳部骨內板

八管腔內の浮腫，骨堆殖による縮小，霄随組織上り

の骨の吸收. 左上方に僅かな督の增殖.

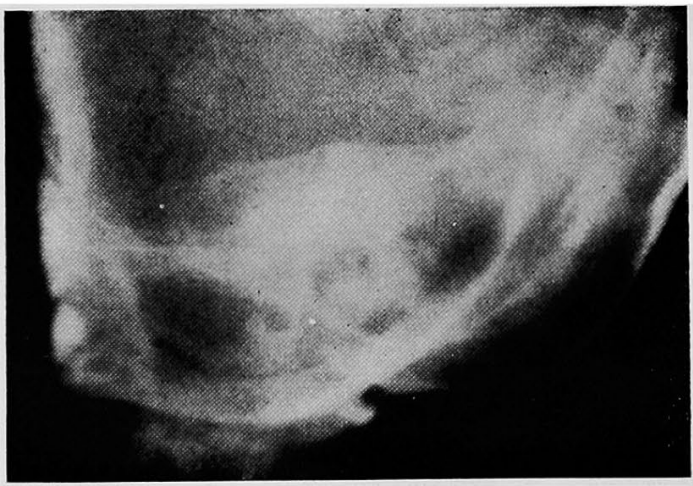

附図 59 第 5 例 左䎲. 骨髅炎柈。

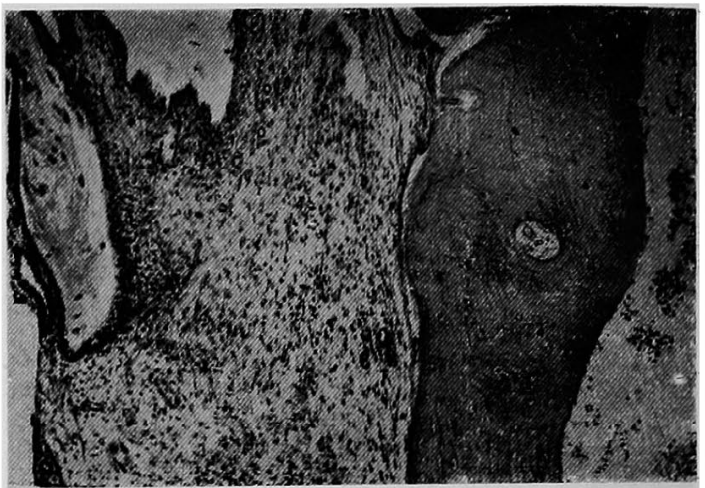

附图 56 第 5 例右乳様润 $(\times 100)$

宵の変性强、. 軟部は肉芽組織. 品状吸收.上皮の

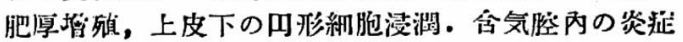
性洷出浰。

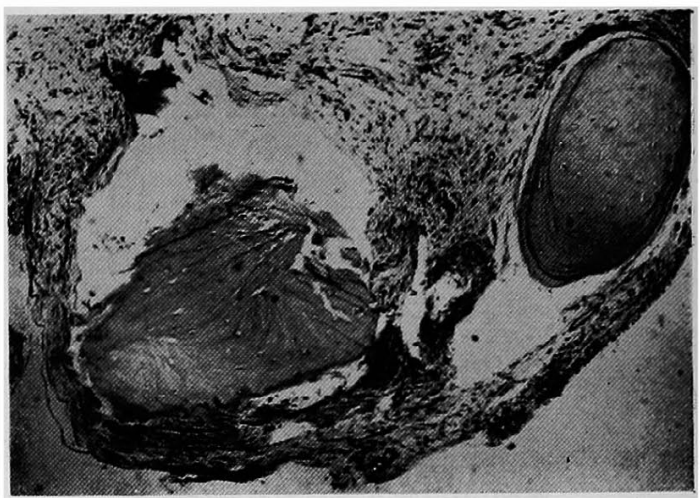

陶图 58 第 5 例 右 頓骨䗋穼

接合線を境として時代の新しい骨の附版，再び简状 吸收。骨を取り囲む闪芽租織。

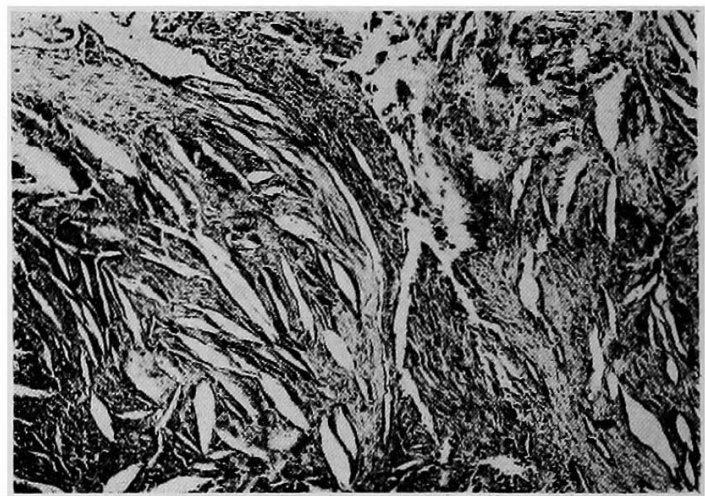

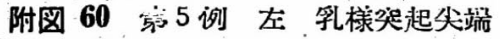

コレステリンの結晶を中心にした肉芽組織・其物型 巨細胞が多数見られ, 組織球, 形質細胞, 多形核白 血球. 


\section{安田論 文附 図 (XI)}

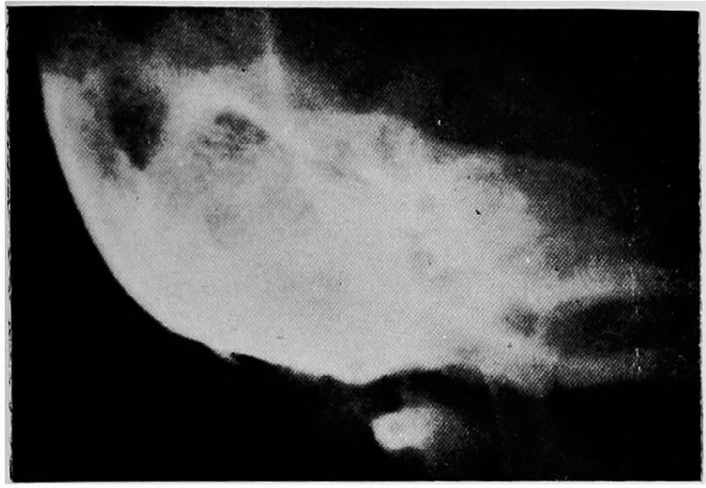

附図 61 第6例 右耳 不鲜明. 一部骨䯣炎様.

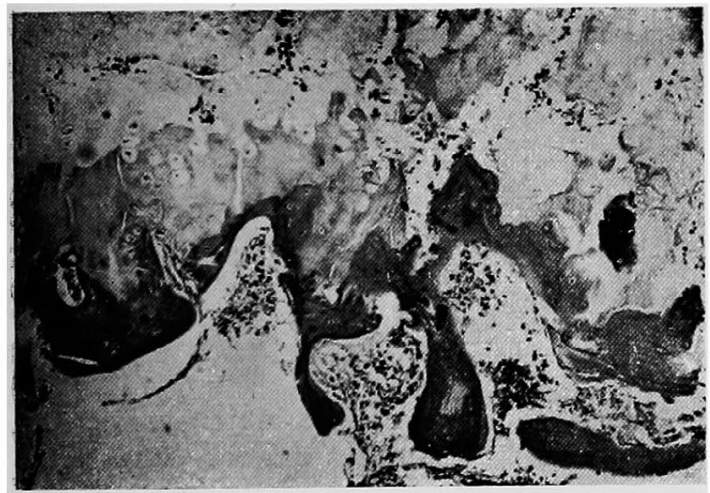

附図 63 第6 冽 右 後頭顆 遗残㳄骨組蟣の化骨.

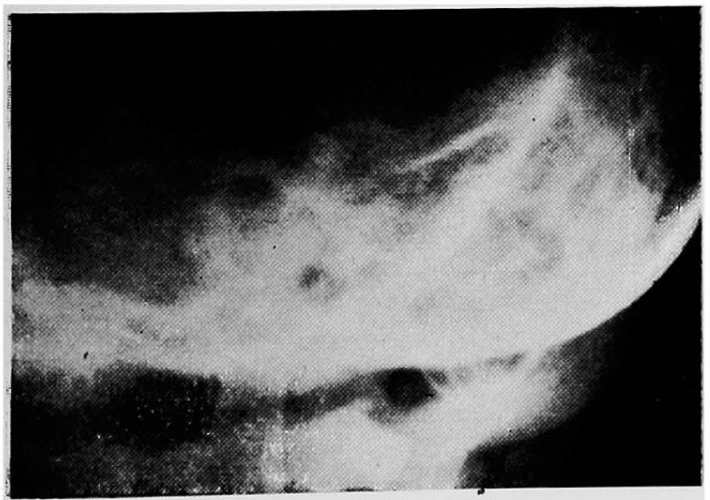

附图 65. 第6 例 左正.

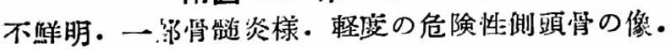

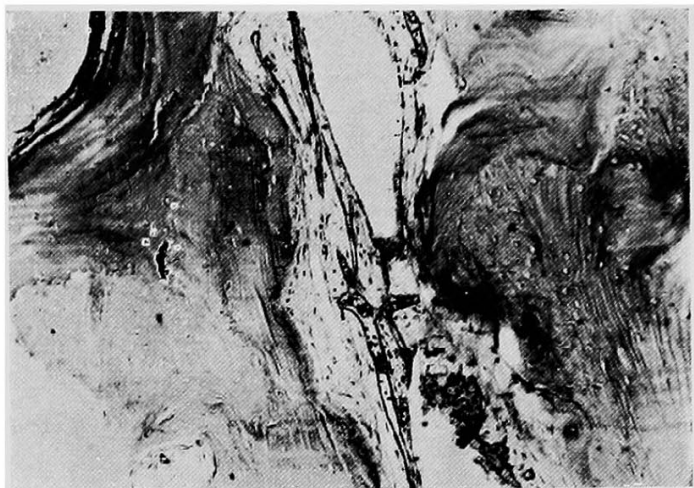

附図 62 第6 例存 乳様润の外測壁( 100 ) 軟部組織よりの骨の筒状吸收。上方に゙時代の其なる 尛.

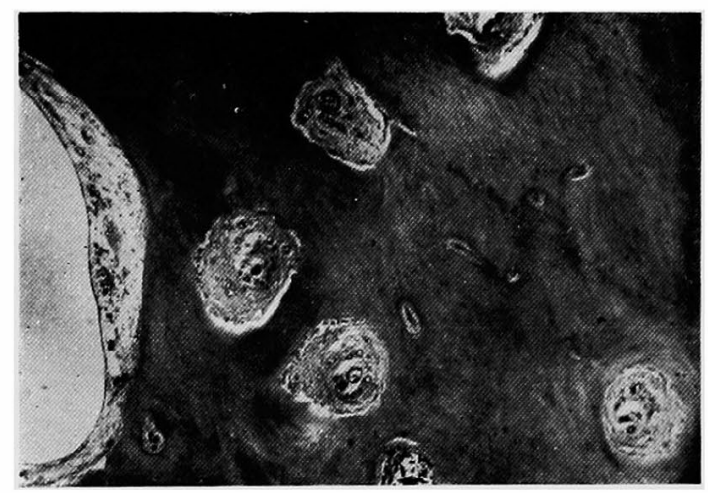

附図 64 管 6 例 右 媔省炇案 $(\times 60)$

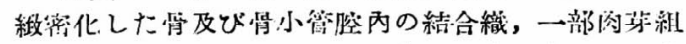

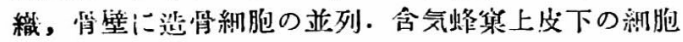
浸洞及び浮陳。

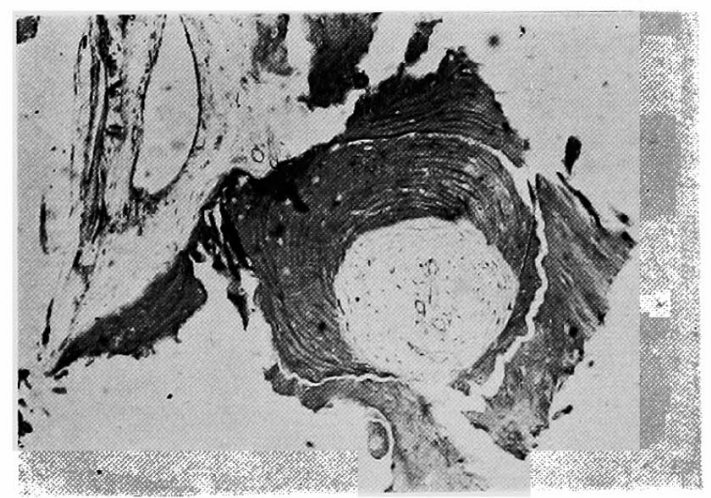

附图 66 左 後峰集列 $(\times 100)$

時代の新しい简の婆性. 肾小管內の浮隀. 
安田論 交附図 (XII)

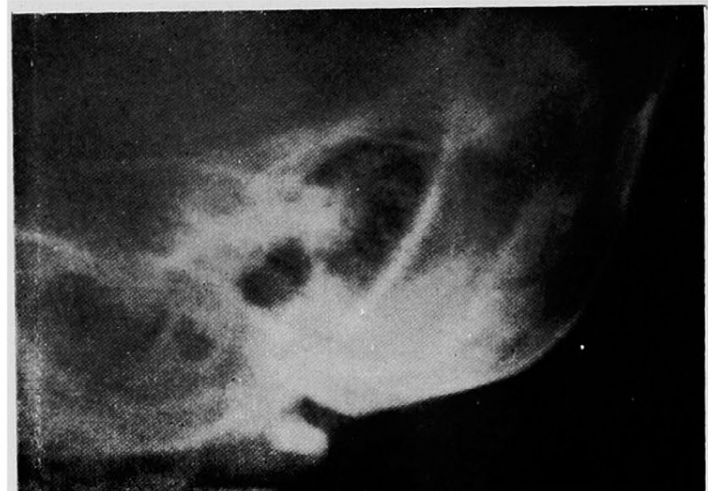

附图 67 等 7 冽 龙耳:

骨嘼炎梯.

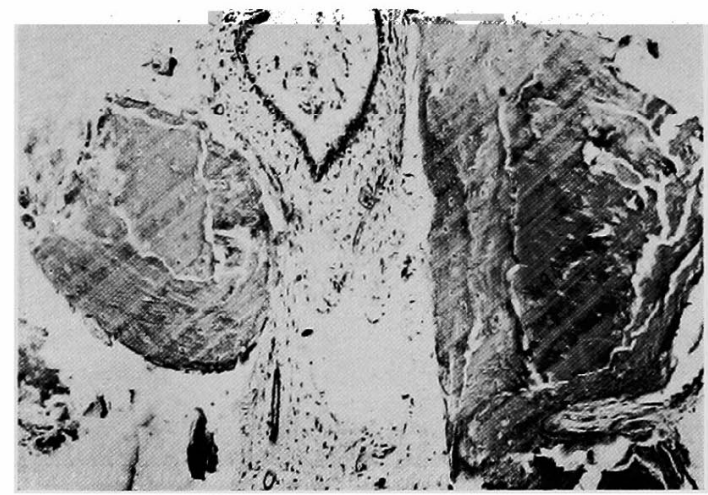

附图 69 缩 7 例 左 外恥道上壁

合气䗋集の上皮は数曆に肥厚堆殖，上皮下の細胞浸

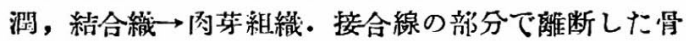
組織は㧤灰化。

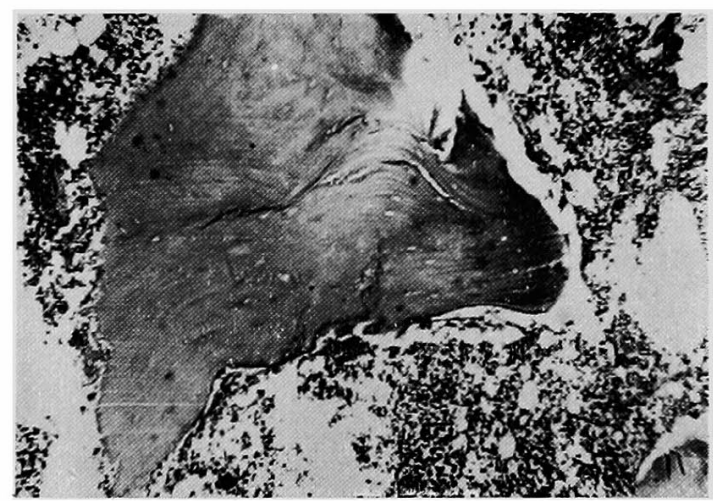

附图 71 第7 例 右 後下烽窠列 (Kramm 法) 狭戔の骨能炎。

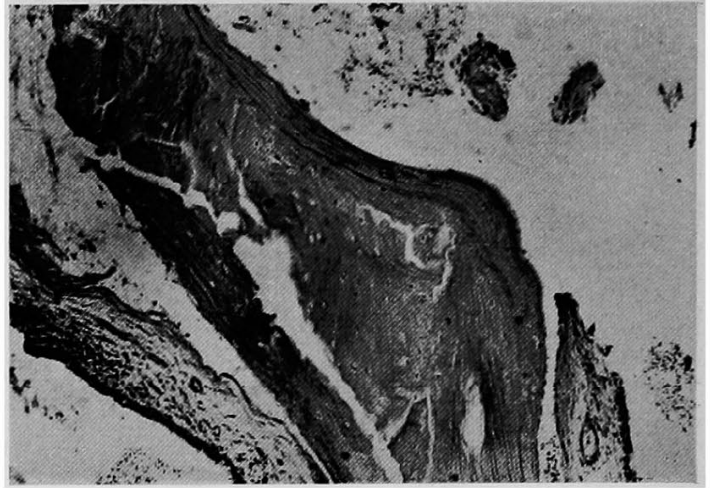

附図 68 第７例 左 乳様洞の外湘壁 $(\times 100)$ 督はや了脆弱化，接合線を境とする時代の新しい骨

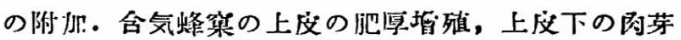
組織及び紏胞浸澗。

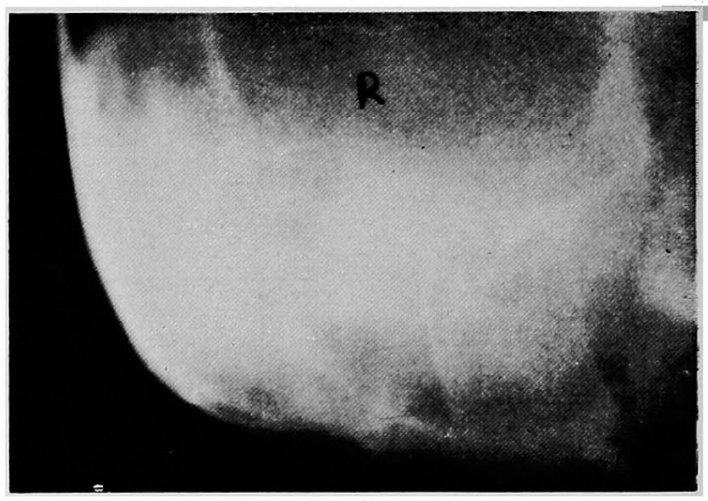

附図 70 第 7 冽 右耳

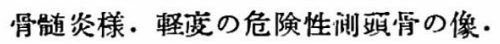

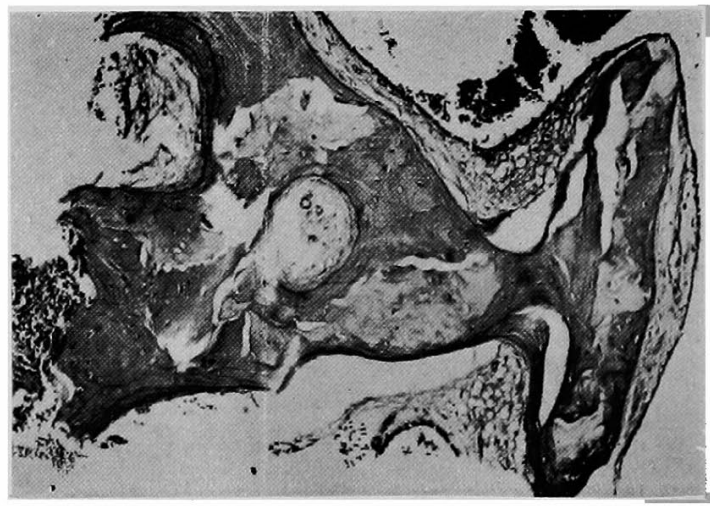

附図 72 第 7 例 右 後, 後上蜂窠列 (山下法) 時代の古以骨の高度の脫灰・ 上皮下の浮腫, 一部脂 㸪制之の変化. 骨小管の浮腫, 血惩の圧迫. 
1953.（ii）錐体尖炎，特にその嗝床；日耳悬第51回 宿㩆報告，別剧，1950.（iii）錐体尖に関する諸問題； 耳矤，21，12，p. 538，1949. 17) 仁保 (正)：寒冷の

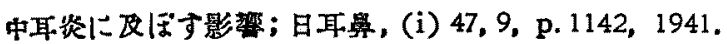
(ii) 47,11 , p. 1420,1941 . (iii) 48,5, p. $540,1942$. (iv) 48,5, p. 582,1942 . (v) 48,6, p. 631, 1942. (vi) 48,6, p. 646, 1942. 18）㛬洨，仁保 (正)：側頭骨炎 （所買広揫の中耳炎）の分矤に就ての一新提唱；日耳累， 48,8, p. 910,1942. 19）仁保（正，本野，小笠原：

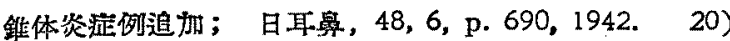

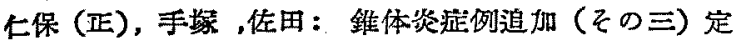

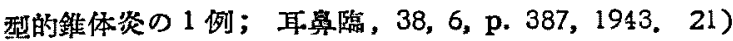

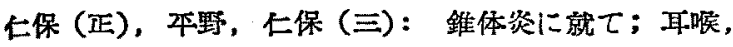
21,12, p. 493, 1949. 22) 保 (正), 仁保 (三), 望 月：錐体炎に就て；(i) 耳喉，20,5, p. 198, 1948. (ii) 耳 唤，21，1， p.9，1949，23）并沢，永井，上保 (正)：

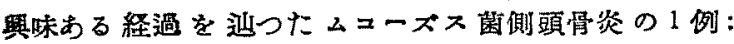
耳喉，22，10，p.413，1950．24）仁保 (三)，永并：側 頭骨炎（所謂中耳炎）に際する骨病变の発生嘫序に就い て;耳喉，22,11, p. 459, 1950. 25) 石川, 上保(正)：

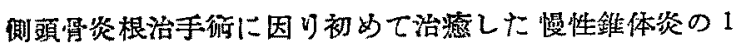

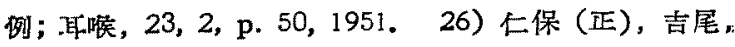
石川: ニペッキー・アルムーア氏法の際に生した大な

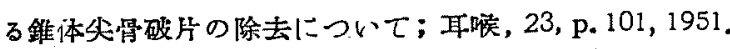
27）代保（三)，仁保（正：：耳性化睡性脳膜桨の 4何，

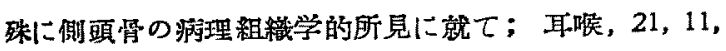
p. 473, 1949. 28) 仁保(正)，仁保（三），吉尾，永井，

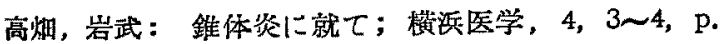
593，1953. 29）化保（正），署武，高畑：錐体炎及ど

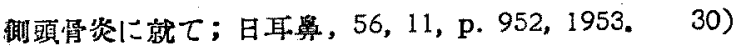
今：近世㵂理解剖学, p. 278, 1941. 31) 佐藤 (保)：

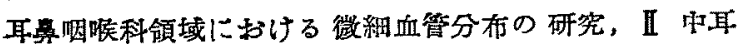
における所見；成医会雑誌，66. 32）鍋谷：日耳耳案， (i) 28, p. 141,1922 . (ii) 31, p. 296, 1925. (iii) 32 ,

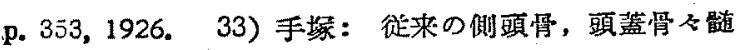
焱の 1 例に就て；耳喉，22，1，p.9，1950. 34）手琭： 所謂中耳炎(㑡頭骨炎) に対する化学猰法の限界; 耳喉， 24,5, p. 206, 1952. 35) 化保 (正), 高畑, 岩武: 所 副慢性中耳炎のシニテンデルス氏法レ線像に就て；日耳

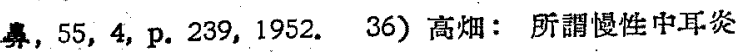

のシニテンベルス氏法レ線像に就て；耳侯， $25,9, p$. 437, 1953，37）土田：所謂先天性潜在性守耳炎に就

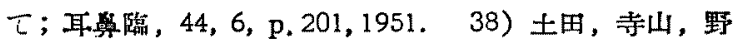

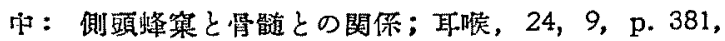
1952. 39) 仁保 (正)，璃烟，岩武：慢性穿孔性中耳

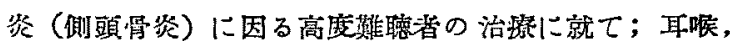
24, 13，p.729，1952. 40）高畑：保存的側頭骨炎根治

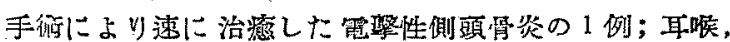
25, 1, p. 24, 1953. 41) 重野：紧性相耳炎と Pn-He-

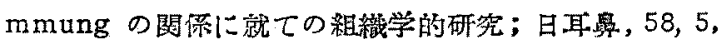
p. 469, 1955. 42) 保(正), 安田：急性㷉耳桨の手

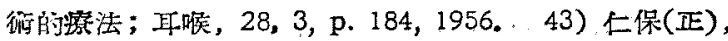
安田：慢性限局性內耳炎の手街的嚓法（附，保存的側

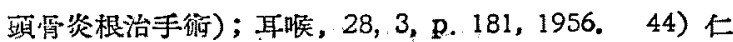

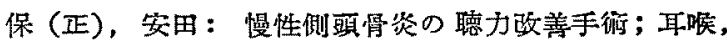
28,3, p. 155, 1956. 45) 吉田(正)：慢性中耳炎の肾

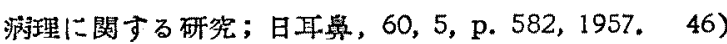

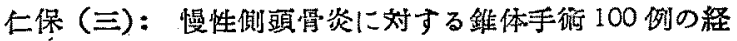

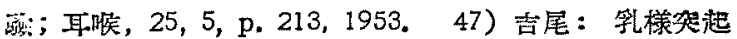

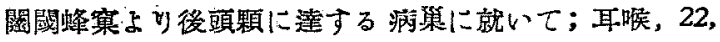

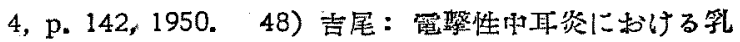
㥞笖起部及錐体組織像について；耳喉，23，4，p. 141，

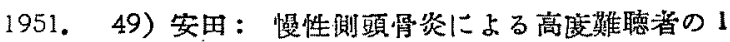
手跒例；日耳與，60，7，p. 1004，1956. 50）佐野，吉

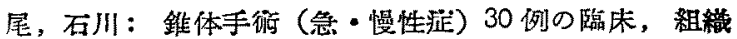
学杓所見；日耳悬，55，6，p，454，1952. 51）吉尾：

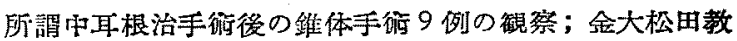
授開諈 20 遇年部念論文勧.

御校閶をいけら゙いた平野新治教授亚びに組織 標本につき御援助をいけだいた横浜医大㴊理吉 村教授に深甚の謝意を交すると共に，終始御指

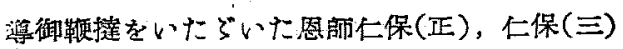
両博士に衰心より感謝致します。

本論交の装旨は日耳舆関東地方会第 29 回大 会，第 340 回例会，第 342 回例会，第59回日

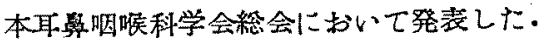

（原稿到着 $=$ 炤和 33.9 .25 日一急載） 